\title{
ABOGADOS CREADORES DE CULTURA
}


ABOGADOS GREADORES DE GULTURA 


\title{
INSTITUTO DE INVESTIGACIONES JURÍDICAS
}

Serie ENSAYOS JURÍDICOS, núm. 40

\section{COORDINACIÓN EDITORIAL}

\author{
Lic. Raúl Márquez Romero
}

Secretario Técnico

Lic. Wendy Vanesa Rocha Cacho

Jefa del Departamento de Publicaciones

Gilda Bautista Ravelo

María Teresa de Jesús Baena Sánchez

Cuidado de la edición

Javier Mendoza Villegas

Formación en computadora

Iván Escoto Mora

Apoyo editorial

Carlos Martín Aguilera Ortiz

Elaboración de portada

La autora agradece a Judith Martín Vargas

por su apoyo en la revisión de las pruebas finales. 


\section{ADRIANA BERRUEGO GARGÍA}

\section{ABOGADOS GREADORES DE GULTURA}
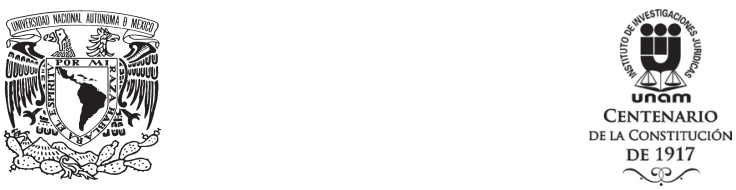

UNIVERSIDAD NACIONAL AUTÓNOMA DE MÉXICO INSTITUTO DE INVESTIGACIONES JURÍDICAS MÉXICO, 2017 
Primera edición: 7 de abril de 2017

DR (C) 2017. Universidad Nacional Autónoma de México INSTITUTO DE INVESTIGACIONES JURÍDICAS

Circuito Maestro Mario de la Gueva s/n Ciudad de la Investigación en Humanidades

Ciudad Universitaria, 04510 Ciudad de México

Impreso y hecho en México

ISBN 978-607-02-9040-4 
A doña Socorro García Barroso y don Cuahtémoc Berrueco 


\section{CONTENIDO}

Introducción $\ldots \ldots \ldots \ldots \ldots \ldots$ IX

CAPÍtUlo PRIMERO. JURISTAS EN EL SIGLO DE

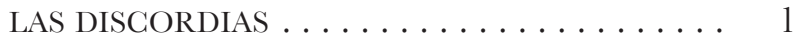

Contexto histórico político $\ldots \ldots \ldots \ldots \ldots \ldots$

Carlos María de Bustamante. . . . . . . . . . 4

José Bernardo Couto . . . . . . . . . . . . . . . 12

José María Lafragua . . . . . . . . . . . . . . . . 20

José María Luis Mora . . . . . . . . . . . . . . . 27

Manuel Orozco y Berra. . . . . . . . . . . . . . 39

Capítulo SEgundo. Abogados de la ERA POSREVOLUCIONARIA . . . . . . . . . . . . . 47

Contexto histórico político . . . . . . . . . . 47 
José Vasconcelos ................. 51

Martín Luis Guzmán. . . . . . . . . . . . . . . . . . 62

Artemio de Valle-Arizpe . . . . . . . . . . . . 72

Ernesto de la Torre Villar . . . . . . . . . . 76

José Fuentes Mares ................. 83

Rubén Bonifaz Nuño. . . . . . . . . . . . . . . . 88

Emilio O. Rabasa . . . . . . . . . . . . . . . . 99

Luis Javier Garrido . . . . . . . . . . . . . . . . . 104

Carlos Montemayor. . . . . . . . . . . . . 110

Víctor Hugo Rascón Banda . . . . . . . . . . 116

Bibliohemerografía . . . . . . . . . . . . . . 123 
Este libro forma parte del acervo de la Biblioteca Jurídica Virtual del Instituto de Investigaciones Jurídicas de la UNAM

\section{INTRODUCGIÓN}

Con el transcurso de los siglos el ejercicio de la profesión jurídica se ha convertido en un tema de estudio e investigación de las ciencias sociales, así lo prueba la amplia bibliografía publicada sobre diferentes aspectos que documentan y analizan la trascendencia de los juristas en la sociedad, a lo cual me referiré después. Tradicionalmente se piensa que los abogados trabajan exclusivamente como litigantes, jueces, ministerios públicos o legisladores. Sin embargo, en el caso de México es notoriamente significativa la presencia de los profesionales del derecho en las altas esferas de la política, en el estudio de la historia, en el cultivo del arte (sobre todo en la rama literaria), y en la planeación y diseño de instituciones educativas de distintos campos de conocimiento.

Desde el siglo XIX la construcción del Estado mexicano tuvo como guías a abogados de diferentes tendencias ideológicas. El proceso emancipador iniciado en 1810 contó con el sustento de preclaros intelectos formados en las escuelas de leyes del virreinato, el tránsito hacia la independencia y la instauración de 
Este libro forma parte del acervo de la Biblioteca Jurídica Virtual del Instituto de Investigaciones Jurídicas de la UNAM

la República, las luchas posteriores entre el centralismo y el federalismo, la defensa de la joven nación ante las invasiones norteamericana y francesa, la Guerra de Reforma, la restauración de la República después del Segundo Imperio, tuvieron como protagonistas a connotados profesionales del derecho. Lo mismo ocurrió en el transcurso del siglo XX. La importancia de algunos personajes estudiados en el libro se valida con el hecho de que sus restos mortales yacen en la rotonda de las personas ilustres de México, además sus obras escritas continúan siendo objeto de interés de las nuevas generaciones y por ello se reeditan, de igual manera las instituciones públicas que contribuyeron a forjar mantienen una vigorosa existencia en nuestra época como la Secretaría de Educación Pública, el Colegio Nacional, la Academia Mexicana de la Lengua, la Comisión Nacional de Libros de Texto Gratuito y la Biblioteca Nacional de México.

Para justificar la utilidad de este libro subrayo que en la actualidad existe una profusa bibliografía de aspectos biográficos de abogados mexicanos. La mayor parte de las biografías de juristas publicadas en nuestro país están dedicadas a personajes destacados en las áreas de impartición de justicia y creación de ordenamientos constitucionales. ${ }^{1}$ En cambio, este libro se

1 Menciono a continuación solamente algunos de los trabajos más representativos de este tema: Alessio Robles, Vito, "Noticia biográfica", en Ramos Arizpe, Miguel, Discursos, memorias e infor- 
Este libro forma parte del acervo de la Biblioteca Jurídica Virtual del Instituto de Investigaciones Jurídicas de la UNAM

centra en resaltar las actividades que los juristas realizaron específicamente en los rubros culturales (utilizo el término cultura en el sentido del ejercicio del arte y la educación), lo cual no es tan frecuente encontrar, ${ }^{2}$

mes, México, UNAM, Coordinación de Humanidades, 1994, Colección Biblioteca del estudiante universitario, núm. 36. Pampillo Baliño, Juan Pablo, Manuel de la Peña y Peña. Un jurista de la Suprema Corte de Fusticia de la Nación, México, Suprema Corte de Justicia de la Nación, 2009. Mayagoitia, Alejandro, "Don Mariano Pontón y Ponce: un jurista en una época de crisis. Notas para su biobibliografía", Anuario Mexicano de Historia del Derecho, México, núm. XV, 2003. Valadés, Diego, "Prólogo" en Montiel y Duarte, Isidro, Tratado de las leyes y su aplicación, México, UNAM, Dirección General de Publicaciones, 1978. Con relación a abogados destacados en la segunda mitad del siglo XX es recomendable la consulta de Fix-Fierro, Héctor, "Los juristas académicos del Instituto de Investigaciones Jurídicas de la UNAM y la construcción jurídica de las nuevas instituciones democráticas", Los abogados y la formación del Estado mexicano, México, UNAM, Instituto de Investigaciones Jurídicas-Ilustre Nacional Colegio de Abogados, 2013. Carbonell, Miguel, forge Carpizo. Una vida entregada a la justicia, México, UNAM, Instituto de Investigaciones Jurídicas, 2012.

2 En México, el análisis de la profesión jurídica se ha abordado con diferentes enfoques; en los rubros de la organización gremial, la colegiación y los estatutos que rigen las asociaciones de abogados sobresalen investigaciones como Cruz Barney, Oscar, "Abogacía: una aproximación a sus organismos internacionales, condecoraciones y distinciones", Reforma Fudicial. Revista Mexicana de Fusticia, México, núms. 21 y 22, enero-diciembre de 2013. Cruz Barney, Oscar, Defensa a la defensa y abogacía en México, México, UNAM, Instituto de Investigaciones Jurídicas-Ilustre y Nacional Colegio de Abogados de México-Ilustre Colegio de 
Este libro forma parte del acervo de la Biblioteca Jurídica Virtual del Instituto de Investigaciones Jurídicas de la UNAM

pese a que está en boga el estudio del patrimonio cultural y se ha incorporado a la Constitución federal mexicana el derecho a la cultura. ${ }^{3}$ Por otra parte, merece atención que en este nuevo libro he incorporado información proveniente del estudio de archivos que se han digitalizado recientemente (como el de el doctor José María Luis Mora) y de documentos que se han localizado en épocas más cercanas.

Quizá la mejor aportación de este trabajo es la integración que he realizado de biografías de abogados que nacieron y destacaron profesionalmente durante el siglo XX. Ello obedece a mi convencimiento de que la historia se está creando día a día, los hechos sociales efectuados hoy, mañana se vuelven parte de la historia reciente, por ello el capítulo segundo del libro ofrece información sistematizada de personalidades del mundo cultural que durante el siglo XX y parte del XXI se convirtieron en herederos de la tradición del gremio jurídico mexicano de ser educadores sociales fungiendo como artífices de las políti-

Abogados de Madrid, 2015. Respecto a la historia de áreas específicas del ejercicio de la profesión jurídica es recomendable Trueba Buenfil, Fernando e Ibarrola Muro, Jorge Claudio, El arte de la memoria notarial. Los trabajos y los días del Estado de México 18081937, México, Gobierno del Estado de México, 2013.

3 El decreto de adición al artículo 4o. de la Constitución Política de los Estados Unidos Mexicanos se publicó el 30 de abril de 2009, en el Diario Oficial de la Federación. 
Este libro forma parte del acervo de la Biblioteca Jurídica Virtual del Instituto de Investigaciones Jurídicas de la UNAM

cas educativas, ejerciendo el magisterio en las aulas universitarias para transmitir a múltiples generaciones los principios rectores del derecho y la política, impulsando la legislación sobre cultura (derecho de autor, cinematografía, libros) y cultivando el arte literario y el estudio de la historia. Sin lugar a dudas existe un hilo conductor entre las políticas educativas del gobierno de Valentín Gómez Farías (ideadas por el abogado José María Luis Mora) y las implementadas después de la Revolución de 1910 por el presidente Álvaro Obregón teniendo como base el pensamiento de José Vasconcelos. De las generaciones de abogados formadas en los paradigmas del vasconcelismo surgirían connotados diplomáticos, escritores, políticos, periodistas, legisladores, maestros, en resumen nuevos edificadores de la nación mexicana del siglo XXI.

Este libro es un avance de una investigación que está en curso, cuyo objetivo final es la creación de un diccionario biográfico sobre abogados que se hayan dedicado a las tareas culturales. El adelanto que presento pretende contribuir al análisis de la participación de los intelectuales mexicanos en el cambio social. Debo recordar, que este tema de investigación lo he cultivado desde hace más de una década y por su naturaleza requiere una constante actualización, así como el ensanchamiento del número de los personajes que se constituyen en objeto de estudio, máxime porque en 
Este libro forma parte del acervo de la Biblioteca Jurídica Virtual del Instituto de Investigaciones Jurídicas de la UNAM

el último lustro México ha perdido, por fallecimiento, a un considerable grupo de intelectuales que fueron columnas de la cultura moderna de nuestro país. Estos abogados formaron parte de importantes organismos como la Academia Mexicana de la Lengua, el Colegio Nacional, el Seminario de Cultura Mexicana, y en su mayoría fueron docentes de la Universidad Nacional Autónoma de México.

He procurado incluir en las biografías fragmentos de las obras de los abogados, con la finalidad de difundir los estilos literarios que a cada uno de ellos los caracterizó, para motivar a los lectores a conocer directamente los textos completos de dichos autores. Con ello busco generar interés entre las nuevas generaciones en la lectura de obras valiosas, por sus cualidades estéticas y por ser testimonios de las preocupaciones de la sociedad mexicana de diferentes décadas, a las cuales dieron voz los abogados utilizando diferentes géneros literarios y periodísticos.

\section{NOTA METODOLÓGICA}

Respecto a las fuentes de consulta utilizadas para integrar esta investigación menciono que hice uso de una extensa gama de libros, revistas, periódicos y documentos de archivo sobre derecho, historia, periodismo, literatura, geografía, pintura, política y otras disciplinas 
Este libro forma parte del acervo de la Biblioteca Jurídica Virtual del Instituto de Investigaciones Jurídicas de la UNAM

afines, ello fue necesario porque varios de los abogados cuyas biografias se presentan en el libro dejaron su legado cultural en publicaciones sobre temas ajenos al derecho. En la parte final del libro aparece enunciado este extenso acervo documental.

Respecto al método de exposición debo aclarar que en el capítulo primero presento las biografías por orden alfabético porque la similitud de edades y la formación jurídica de los personajes los hicieron converger en los mismos sucesos históricos, son verdaderamente contemporáneos y todos fallecieron en el siglo XIX. En cambio los abogados que son biografiados en el capítulo segundo nacieron unos a finales del siglo XIX y otros en diferentes décadas del siglo XX, lo cual hizo que su actuar público, sus ideas y sus áreas de interés profesional fueran distintos, ello en virtud de los cambios tan acelerados que vivió el mundo, y México en específico, por el uso de nuevas tecnologías de la información y por los sucesos bélicos internacionales e internos que generaron modificaciones notables en la economía, la ciencia, el derecho, las artes y el ejercicio de la política. Por esta causa preferí presentar las biografías utilizando un criterio cronológico con base en las fechas de nacimiento de los sujetos en estudio. No puedo omitir hacer mención, que las necesidades sociales derivadas de la Revolución mexicana de 1910 y el contenido de la Constitución de 1917 orientaron el 
Este libro forma parte del acervo de la Biblioteca Jurídica Virtual del Instituto de Investigaciones Jurídicas de la UNAM

trabajo de abogados como José Vasconcelos y Martín Luis Guzmán, y que las características del sistema político en que vivieron fue un factor determinante de su estilo literario. En cambio otros abogados, los nacidos durante la cuarta década del siglo XX, impulsaron nuevas instituciones culturales y jurídicas que son productos de los cambios tecnológicos de la posguerra, estos profesionales del derecho también tuvieron márgenes de maniobra más amplios para desenvolverse en la política gracias a que el sistema de poder tuvo que ceder en su autoritarismo ante la creciente presión de grupos emergentes que lucharon por la democratización del país. En consecuencia de ello el ejercicio de la escritura de estos intelectuales también fue innovador en sus temáticas y en su forma. Es significativo que desde 1946 la presidencia de México ha sido ejercida por civiles, siendo éste un factor que modificó la forma de ejercer el poder.

La relativa calma que se disfrutó durante la segunda parte del siglo XX trajo consigo un notable desarrollo de las instituciones de educación superior, también se industrializó México con una marcada dependencia hacia los capitales extranjeros, esto implicó nuevas formas de marginación social y actos de autoritarismo por parte de los gobiernos para sofocar el descontento popular, estas realidades dieron tema a las obras de abogados como Luis Javier Garrido, Car- 
Este libro forma parte del acervo de la Biblioteca Jurídica Virtual del Instituto de Investigaciones Jurídicas de la UNAM

los Montemayor y Víctor Hugo Rascón Banda, quienes se convirtieron en líderes de opinión por la calidad de su trabajo intelectual y por sus opiniones críticas hacia las injusticias propiciadas por el sistema político mexicano. Incorporar información biográfica de este sector de intelectuales contribuye a realizar un estudio más completo del ejercicio del periodismo, la literatura y la investigación sobre ciencia política realizado por profesionales del derecho de diversas tendencias ideológicas. 
Este libro forma parte del acervo de la Biblioteca Jurídica Virtual del Instituto de Investigaciones Jurídicas de la UNAM

\section{GAPÍTULO PRIMERO}

\section{JURISTAS EN EL SIGLO DE LAS DISCORDIAS}

\section{CONTEXTO HISTÓRICO POLÍTICO}

Al comienzo del siglo XIX, en la Nueva España, se sentían los vientos renovadores que circulaban desde el antiguo continente influyendo en la aspiración de las clases cultas de esta importante colonia de implementar nuevos sistemas jurídicos y en renovar la sociedad mediante la difusión de los conocimientos científicos y las ideas políticas, para esta última aspiración utilizaron publicaciones de revistas y periódicos, los cuales coadyuvaron a acrecentar el conocimiento de las riquezas naturales de nuestro territorio, las costumbres de sus habitantes y sus idiomas mal llamados dialectos. En 1805 surgió el primer periódico cotidiano de la Nueva España llamado Diario de México cuyo responsable fue el abogado Carlos María de Bustamante, quien tendría un papel protagónico en la historia del México independiente porque participó en la creación de ordenamientos jurídicos relevantes y continuó ejerciendo el periodismo y la escritura de obras sobre historia. 
Este libro forma parte del acervo de la Biblioteca Jurídica Virtual del Instituto de Investigaciones Jurídicas de la UNAM

En 1810 se inició el movimiento independentista en la Nueva España mismo que concluyó en 1821, generando una confrontación entre los grupos políticos de la época respecto a la forma de gobierno que habría de tener la nueva nación. El primer gobierno del México independiente estuvo a cargo de la Junta Provisional Gubernativa, nombrada por Agustín de Iturbide, uno de los consumadores de la Independencia, la Junta eligió a la Regencia Provisional. Posteriormente, de 1822 a 1823, Agustín de Iturbide se impuso como emperador; surgieron entonces rencillas entre los exinsurgentes, por la marginación que padecieron porque Iturbide colocaba a los borbonistas en los cargos públicos. Tras la derrota del Primer Imperio se estableció la República y vendría otro enfrentamiento entre los partidarios del federalismo contra los del centralismo. En la segunda década del siglo XIX las facciones políticas se organizaban principalmente en logias masónicas, las cuales generalmente eran dirigidas por abogados prominentes.

En el rubro jurídico la inestabilidad política se reflejó en la expedición de varias Constituciones y de múltiples ordenamientos secundarios que regulaban todas las relaciones sociales. Entre las principales preocupaciones de los gobernantes de esta centuria se encontró la educación (José María Luis Mora) y el desarrollo de la ciencia y el arte (José María Lafragua), se buscó catalogar y preservar los bienes culturales tan- 
Este libro forma parte del acervo de la Biblioteca Jurídica Virtual del Instituto de Investigaciones Jurídicas de la UNAM

to materiales (José Bernardo Couto) como intangibles (Manuel Orozco y Berra) y se impulsaron diferentes normatividades para la consecución de dichas metas.

Los personajes biografiados en este capítulo intervinieron de manera directa en la conformación de la mayoría de las normas constitucionales de la época y en la creación del resto del marco regulador del país que dio sustento a la tradición jurídica mexicana que, incluso en la actualidad continúa operando en las leyes vigentes en el siglo XXI. En las disciplinas que hoy conocemos como humanidades y ciencias sociales los abogados ejercieron la conducción pues eran el estamento culto de la sociedad. Algunos de ellos fueron criticados por las decisiones que tomaron en momentos aciagos para México, como la guerra contra los Estados Unidos de Norteamérica (1846-1848) y por incorporarse a la administración del emperador Maximiliano de Habsburgo.

El siglo XIX mexicano también se caracterizó por las luchas entre conservadores y liberales, de las mismas emergieron líderes políticos que dotarían al país de un conjunto de ordenamientos jurídicos relevantes, como las Leyes de Reforma, éstas surgieron de la guerra que detonó la innovadora Constitución de 1857, que enunció un conjunto de garantías individuales y no estableció ninguna religión de Estado. Tras el Segundo Imperio se restableció la República triunfando con ella la ideología liberal, teniendo como dirigen- 
Este libro forma parte del acervo de la Biblioteca Jurídica Virtual del Instituto de Investigaciones Jurídicas de la UNAM

te al presidente Benito Juárez, quien gobernó hasta 1872, en la era juarista se logró desarrollar un sistema normativo moderno, se impulsó la creación y uso de códigos sustantivos y adjetivos, penales y civiles. Tuvo un fuerte impulso la educación con la instauración de la Escuela Nacional Preparatoria y la expedición de leyes y reglamentos sobre educación. En gran parte de estos sucesos históricos participaron los juristas cuyas biografías se presentan a continuación.

\section{Carlos María de Bustamante}

Nació en Oaxaca, Oaxaca el 4 de noviembre de 1774, falleció en la Ciudad de México el 21 de septiembre de 1848. A partir de 1789 inició sus estudios de filosofía en el Colegio Seminario de Oaxaca, posteriormente estudió en la Ciudad de México donde obtuvo el grado de bachiller en artes. Estudió jurisprudencia en la Ciudad de México pero obtuvo el título de abogado en Guadalajara en 1801. ${ }^{1}$

Se distinguió como un prolífico autor de textos sobre historia y tuvo una notable participación en el periodismo mexicano el cual ejerció de manera simultá-

1 Vázquez, Josefina Zoraida, "Presentación", en Bustamante, Carlos María de, El nuevo Bernal Díaz del Castillo, o sea, historia de la invasión de los angloamericanos en México, México, Consejo Nacional para la Cultura y las Artes, 2005, p. 19. 
Este libro forma parte del acervo de la Biblioteca Jurídica Virtual del Instituto de Investigaciones Jurídicas de la UNAM

nea con las actividades legislativas y de litigante, fue un personaje muy cercano a don José María Morelos con quien contribuyó en la creación de documentos jurídicos fundamentales. La trascendencia de Carlos María de Bustamante en el rubro periodístico derivó de las siguientes acciones. En 1805, conjuntamente con Jacobo de Villaurrutia fue fundador del periódico Diario de México, primera publicación cotidiana que circuló en la Nueva España, el cual tiene gran relevancia no sólo por ser el primer diario hecho y editado en nuestro país, también es importante porque generó nuevas prácticas en el campo de la comunicación, toda vez que los lectores participaban con comentarios y quejas que eran difundidas en el periódico, y con ello el Diario de México se transformó en un verdadero medio de comunicación y no solamente de difusión como lo fueron las hojas volantes y las Gacetas. El Diario de México circuló, casi sin interrupciones, del 1o. de octubre de 1805 al 4 de enero de 1817. En su larga trayectoria también fue víctima de la censura virreinal ${ }^{2}$ y de la represión por ejercer la libertad de imprenta que estableció la Constitución de Cádiz de 1812. El Diario de México hizo importantes contribuciones al desarrollo

2 Véase el minucioso estudio de este periódico hecho por Ruiz Castañeda, María del Carmen, "El Diario de México (18051817)", en Reed Torres, Luis y Ruiz Castañeda, María del Carmen, El periodismo en México, 500 años de historia, 3a. ed., México, Edamex, 1995, pp. 81-104. 
Este libro forma parte del acervo de la Biblioteca Jurídica Virtual del Instituto de Investigaciones Jurídicas de la UNAM

de la literatura mexicana porque abrió sus páginas a don José Joaquín Fernández de Lizardi y a los integrantes de la asociación Arcadia de México (primera asociación literaria de nuestro país, cuya característica fue el impulso al neoclasicismo literario), sobresaliendo por sus contribuciones a este periódico el poeta fray Manuel Martínez de Navarrete. ${ }^{3}$

En su amplia trayectoria dentro del periodismo Carlos María de Bustamante realizó publicaciones en el Mosaico Mexicano, en el cual insertó el texto denominado "Documentos inéditos y curiosos para la historia de México". ${ }^{4}$ Se debe subrayar que el Mosaico mexicano fue una revista enciclopédica destinada a difundir entre la población conocimientos relevantes sobre ciencias exactas, arqueología, historia, economía, medicina, artes y legislación. En 1812 publicó el semanario El juguetillo en el que criticó a Félix María Calleja ${ }^{5}$ por su crueldad con los insurgentes.

3 Martínez Luna, Esther, "Diario de México: «ilustrar a la plebe»", en Clark, Belem y Speckman, Elisa (eds.), La república de las letras. Asomos a la cultura escrita del México decimonónico, México, Coordinación de Humanidades, 2005, vol. II, pp. 47-53.

4 Ruiz Castañeda, María del Carmen, "La prensa científica y literaria (1830-1850)", Gaceta Bibliográfica, México, núm. 22, abriljunio de 2003, p. 18.

5 Félix María Calleja fue un general realista que combatió a los Insurgentes, aprehendió al cura Miguel Hidalgo y posteriormente mantuvo sitiadas a las fuerzas de don José María Morelos en Cuautla, en 1812. Calleja fue el 60o. Virrey de la Nueva España. 
Este libro forma parte del acervo de la Biblioteca Jurídica Virtual del Instituto de Investigaciones Jurídicas de la UNAM

En el campo de la historia Carlos María de Bustamante brilló por diferentes obras. En 1833 escribió su autobiografía titulada Hay tiempos de hablar, y tiempos de callar, dicho texto fue redactado con la finalidad de librarse del destierro decretado en su contra por las autoridades mexicanas. ${ }^{6}$ Dentro de este texto es interesante la narración del encarcelamiento que sufrió Bustamante en San Juan de Ulúa, Veracruz; en esa prisión pasó largos trece meses en los que padeció, junto con los demás reclusos, hambre, insalubridad y demás vejaciones a su dignidad humana. Se le liberó el 23 de mayo de 1819. Carlos María de Bustamante también fue autor de los libros Cuadro histórico de la revolución de 1810, El Gabinete mexicano durante el segundo periodo de la administración del Excmo. Señor presidente D. Anastacio Bustamante, Apuntes para la historia del gobierno del general D. Antonio López de Santa Anna, El nuevo Bernal Diaz del Castillo o sea historia de la invasión de los angloamericanos a México, y un diario personal que Bustamante redactó con sucesos relevantes, mismo que es conocido como Diario histórico de México. En él aparecen comentarios sobre las normas constitucionales que le tocó elaborar a Bustamante y las ceremonias en las cuales fueron juradas esas disposiciones (Acta Constitu-

6 Bustamante, Carlos María de, Hay tiempos de hablar y tiempos de callar, publicado en la página electrónica del Instituto Nacional de Estudios Históricos de las Revoluciones de México, en http:// inehrm.gob.mx. 
Este libro forma parte del acervo de la Biblioteca Jurídica Virtual del Instituto de Investigaciones Jurídicas de la UNAM

tiva de la Federación Mexicana y Constitución Federal de los Estados Unidos Mexicanos). ${ }^{7}$

En lo correspondiente al trabajo de Bustamante en los rubros político y jurídico sobresale su participación en el movimiento de Independencia, al cual se unió en 1812, con el sacerdote José María Morelos y Pavón. El abogado oaxaqueño fue el autor de la versión original del discurso pronunciado por Morelos en la apertura de las sesiones del Congreso de Chilpancingo ${ }^{8}$ (14 de septiembre de 1813), también colaboró en la redacción de los Sentimientos de la Nación ${ }^{9}$ (texto presentado también el 14 de septiembre de 1813 y leído por Juan Nepomuceno Rosáins, secretario de Morelos) y la Constitución de Apatzingán, cuyo nombre auténtico fue Decreto Constitucional para la Libertad de la América Mejicana, de fecha 22 de octubre de 1814, documento

7 Véase Bustamante, Carlos María de, Diario histórico de México enero-diciembre de 1824, México, Instituto Nacional de Antropología e Historia, 1981, pp. 27, 28, 140 y 141.

8 Cfr. Garrido, Felipe, "El siervo de la nación, José María Morelos", en Morelos y Pavón, José María, Sentimientos de la Nación, México, Consejo Nacional para la Cultura y las Artes, 2010, Colección Summa Mexicana, pp. 21 y 101.

9 La correspondencia en la que constan las reacciones entre Morelos y Bustamante respecto al Congreso de Chilpancingo y los Sentimientos de la Nación se halla publicada en Ibarra Palafox, Francisco (introducción y selección), El Congreso de Anáhuac y la Constitución de Apatzingán. Obra documental, México, UNAM, Instituto de Investigaciones Jurídicas, 2016, pp. 127-140. 
Este libro forma parte del acervo de la Biblioteca Jurídica Virtual del Instituto de Investigaciones Jurídicas de la UNAM

que se convirtió en la primera Constitución mexicana, pero que no estuvo en vigor. Bustamante fue uno de los signatarios del Acta de Independencia de la América septentrional, firmada en Chilpancingo, el 6 de noviembre de $1813 .{ }^{10}$ Por otra parte, en 1813 el abogado Bustamante estuvo a cargo de la publicación del periódico Correo Americano del Sur, tarea que efectuaba conjuntamente con José Manuel de Herrera en Oaxaca.

Tras la consumación de la Independencia, Bustamante presentó algunas propuestas en materia penal en la Soberana Junta Provisional Gubernativa del Imperio mexicano, aunque no fue vocal (esta Junta realizó trabajos legislativos del 22 de septiembre de 1821 al 24 de febrero de 1822); en esta etapa Bustamante enfrentó un problema legal por las publicaciones que realizó en el periódico La abispa de Chilpancingo, el abogado logró que se le conmutara la pena de prisión por una multa. Por otra parte, casi al finalizar las actividades de la Junta, Bustamante logró ser nombrado como parte de la comisión que elaboraría un código criminal. ${ }^{11}$

10 Torre Villar, Ernesto de la, La Constitución de Apatzingán y los creadores del Estado mexicano, primera reimpresión, 2a. ed., México, UNAM, Instituto de Investigaciones Históricas, 2010, p. 47. También la firmaron Andrés Quintana Roo, Ignacio López Rayón, José Manuel Herrera, José Sixto Verduzco, José María Liceaga y Cornelio Ortiz Zárate.

11 Véase López Betancourt, Eduardo, "Labor legislativa de la Soberana Junta Provisional Gubernativa del Imperio mexicano e 
Este libro forma parte del acervo de la Biblioteca Jurídica Virtual del Instituto de Investigaciones Jurídicas de la UNAM

Posteriormente Bustamante formó parte del segundo Congreso Constituyente (denominado Soberano Congreso Constituyente Mexicano) que se instaló el 7 de noviembre de 1823, y emitió el Acta Constitutiva de la Federación Mexicana el 31 de enero de 1824. El Acta establecía formalmente el gobierno republicano y el pacto federal. ${ }^{12}$ Después Bustamante, en representación del Estado de México, perteneció al Constituyente de 1824, que elaboró la Constitución Federal de los Estados Unidos Mexicanos, publicada el 5 de octubre de 1824. Tras un decenio de implementación del régimen federal en México surgió una lucha para establecer el centralismo, para este fin se emitieron normativas constitucionales (perdiendo vigor la de 1824) conocidas como las Bases para la nueva Constitución (1835) y las Siete leyes o Leyes constitucionales, en este último conjunto jurídico intervino como miembro del constituyente el abogado Carlos María de Bustamante con la calidad de representante del Departamento de Oaxaca. Las Siete Leyes establecieron la creación del Supremo Poder Conservador, de él formó parte Bus-

intervenciones en la misma de Carlos María de Bustamante", en Bernal, Beatriz (coord.), Memoria del IV Congreso de Historia del derecho mexicano (1986), México, UNAM, Instituto de Investigaciones Jurídicas, 1988, t. II, pp. 595-606.

12 El Acta aparece publicada en Antecedentes históricos y Constituciones politicas de los Estados Unidos Mexicanos, México, Secretaría de Gobernación, 2009, pp. 197-205. 
Este libro forma parte del acervo de la Biblioteca Jurídica Virtual del Instituto de Investigaciones Jurídicas de la UNAM

tamante conjuntamente con Melchor Muzquiz (presidente), Manuel de la Peña y Peña, José Cirilo Gómez y Anaya, y Francisco Manuel Sánchez de Tagle.

Después de constatar la intensa participación política de Bustamante es admirable que lograra tan vasta y valiosa producción intelectual, Ernesto de la Torre verificó la existencia de 107 títulos bibliográficos del abogado oaxaqueño. ${ }^{13}$ Carlos María de Bustamante fue un político e historiador controvertido, por lo cual ha sido merecedor de variados estudios de connotados historiadores como Lucas Alamán ${ }^{14}$ y Edmundo O'Gorman. ${ }^{15}$ En honor a su producción literaria Bustamante fue incorporado como miembro fundador de la Academia de la Lengua (1835) siendo ésta el antecedente primigenio de la actual Academia Mexicana de la Lengua. En los siglos posteriores a su fallecimiento, Bustamante sigue siendo objeto de homenajes, en las conmemoraciones del bicentenario de la independencia el gobierno mexicano emitió una moneda (con valor de cinco pesos) en la que aparece la efigie de don Carlos María de Bustamante. De

13 Torre Villar, Ernesto de la, La independencia de México, 2a. ed., México, Fondo de Cultura Económica, 2010, p. 156.

14 Alamán, Lucas, "Noticias biográficas del licenciado Carlos María de Bustamante y juicio crítico de sus obras", Documentos diversos, México, Jus, 1849, vol. III.

15 O’Gorman, Edmundo, Guía bibliográfica de Carlos María de Bustamante, México, Fundación Cultural Condumex, 1967. 
Este libro forma parte del acervo de la Biblioteca Jurídica Virtual del Instituto de Investigaciones Jurídicas de la UNAM

igual forma, sus investigaciones continúan publicándose y son fuente de información para los historiadores contemporáneos.

\section{José BERnARdo COUTO}

Su nombre completo fue José Bernardo Couto Pérez. Nació en Orizaba, Veracruz en 1803 y falleció en la Ciudad de México en noviembre de 1862. Efectuó sus estudios de abogado (humanidades y jurisprudencia) en el Colegio de San Ildefonso, donde fue alumno de don José María Luis Mora, con quien inició su trayectoria laboral. Ambos tuvieron una amistad sólida que perduró hasta la muerte de Mora, Couto redactó una biografía del "padre del liberalismo mexicano". Uno de los primeros éxitos de Couto fue la obtención del premio otorgado por el Congreso Constituyente del Estado de México, en 1825, por la obra titulada Disertación sobre la naturaleza y límites de la autoridad eclesiástica, la cual se publicó firmada con el seudónimo Norberto Pérez Cuyado. ${ }^{16}$ En 1827 el joven José Bernardo concluyó su formación profesional y obtuvo el título respectivo

16 De lo cual dio cuenta Couto en una carta del 12 de enero de 1858, dirigida a los redactores del periódico La Cruz, en el cual publicó su Discurso sobre la Constitución de la iglesia. La disertación de Couto es parte de la Colección Lafragua a cargo de la Benemérita Universidad Autónoma de Puebla. 
Este libro forma parte del acervo de la Biblioteca Jurídica Virtual del Instituto de Investigaciones Jurídicas de la UNAM

ocupando la cátedra de derecho público. En 1828 se incorporó como miembro de la legislatura local de Veracruz. En la década de los treinta del siglo XIX se publicó el Dictamen de la Comisión Especial de la Cámara de Senadores, sobre el cambio de la forma de gobierno, y voto particular del Sr. Couto. ${ }^{17}$ En la presidencia de José Joaquín de Herrera, Couto se encargó del Ministerio de Justicia, específicamente en el periodo del 14 de agosto al 19 de octubre de 1845.

En 1848 el jurista Couto fue nombrado miembro del triunvirato negociador del Tratado de Guadalupe Hidalgo, ${ }^{18}$ firmado por México con los Estados Unidos de Norteamérica para poner fin a la invasión a nuestro país perpetrada desde 1846, se recordará siempre que a través de este Tratado sufrimos la merma de la mitad del territorio de la República mexicana. Posteriormente, en 1852, don José Bernardo Couto fungió como ministro de la Suprema Corte de Justicia.

Con el transcurso del tiempo Couto destacó en los grupos de poder de ideología conservadora, en virtud

17 Publicada por la Imprenta del Águila, México, 1835.

18 También fueron negociadores Luis G. Cuevas y Miguel Atristain. Los razonamientos de los representantes mexicanos para aceptar el Tratado se hallan en una exposición de motivos que los tres personajes dirigieron al gobierno mexicano, texto que puede consultarse en Vázquez, Josefina Zoraida, México y el mundo. Historia de sus relaciones exteriores, México, El Colegio de México, 2010 , t. I. 
Este libro forma parte del acervo de la Biblioteca Jurídica Virtual del Instituto de Investigaciones Jurídicas de la UNAM

de lo cual su relación con Antonio López de Santa Anna fue estrecha. En la última gestión presidencial de Santa Anna (cuando el gobierno mexicano vendió La Mesilla a Estados Unidos de Norteamérica), Couto se convirtió en miembro de las Academias Mexicanas de la Lengua y de Historia precisamente por nombramiento de Santa Anna, en 1854. ${ }^{19}$ Unos meses antes, en 1853, el jurista veracruzano formó parte del jurado calificador que eligió la letra del himno nacional mexicano, ${ }^{20}$ según la convocatoria emitida por el propio presidente Santa Anna.

Durante la Guerra de Reforma, concretamente en la presidencia de Félix Zuloaga, José Bernardo Couto se desempeñó como presidente del Consejo de Gobierno de la República creado por el propio Zuloaga, Consejo que aprobó el Estatuto Orgánico Provisional de la República mexicana. ${ }^{21}$ En 1858 se convirtió en

19 Los decretos pueden consultarse en Legislación mexicana o colección completa de las disposiciones legislativas expedidas desde la independencia de la República, ordenadas por Manuel Dublán y José María Lozano, en http://biblio.colmex.mx/bib.dig.

20 El jurado también estuvo integrado por Manuel Carpio y José Joaquín Pesado. La letra original del himno puede consultarse en Campillo Cuautli, Héctor, El himno nacional mexicano. Origen, historia y significado de nuestro himno, México, Fernández editores, 1998, pp. 8-11.

21 Cruz Barney, Oscar, La República central de Félix Zuloaga y el Estatuto Orgánico Provisional de la República de 1858, México, UNAM, Instituto de Investigaciones Jurídicas, 2009, p. 1. 
Este libro forma parte del acervo de la Biblioteca Jurídica Virtual del Instituto de Investigaciones Jurídicas de la UNAM

el rector del Ilustre y Nacional Colegio de Abogados. Es de destacar que el abogado veracruzano además de participar en política también ejerció la carrera jurídica siendo asesor del Tribunal Mercantil de la Ciudad de México en las décadas de los cuarenta y cincuenta del siglo XIX.

José Bernardo Couto tuvo una amplia intervención en el sector cultural de nuestro país ya que ejerció la presidencia de la Junta Directiva de la Academia de San Carlos durante el lapso de 1852-1861. Institución desde la cual estableció una política de obtención de obras pictóricas para la Academia, mismas que provenían de las colecciones poseídas por las órdenes religiosas; la Academia entregaba a cambio dinero o copias de las pinturas intercambiadas hechas por los alumnos de San Carlos. El acervo plástico logrado por Couto fue parte de la Pinacoteca Virreinal de San Diego $^{22}$ y en la actualidad se halla en el Museo Nacional de Arte.

A la intervención del abogado veracruzano se debe la creación de la estatua a Cristóbal Colón que se halla ubicada en la Plaza de Buenavista, en la Ciudad de México, esta obra fue realizada a instancias de Couto por el escultor catalán Manuel Vilar en 1858, y por di-

22 Para conocer las obras que integraban esta colección véase Sodi Pallares, Ernesto, Pinacoteca Virreinal de San Diego, México, Populibros La Prensa, 1969. 
Este libro forma parte del acervo de la Biblioteca Jurídica Virtual del Instituto de Investigaciones Jurídicas de la UNAM

versas razones fue fundida y expuesta al público hasta 1892 con motivo del IV centenario del descubrimiento de América. ${ }^{23}$

Couto efectuó investigaciones de tipo histórico, una parte de ellas fueron las biografías de José María Luis Mora, Javier Echeverría y de los sacerdotes Andrés Cavo y Pedro José Márquez, las cuales se incorporaron al Diccionario universal de historia y geografia, coordinado por Manuel Orozco y Berra. ${ }^{24}$ Además, se dio tiempo para crear el cuento titulado "La mulata de Córdoba y la historia de un peso". ${ }^{25}$ El jurisconsulto Couto también creó el Discurso sobre la Constitución de la Iglesia (1857) que fue publicado en el periódico conservador $L a$ Cruz.

La obra póstuma del célebre jurista veracruzano fue Diálogo sobre la historia de la pintura en México, la cual quedó concluída unos meses antes del deceso de Couto y ha sido publicada desde el siglo XIX; por el valor de la información que aporta ha continuado difundién-

23 Villalpando, José Manuel, Los monumentos a Cristóbal Colón en la Ciudad de México, México, versión electrónica publicada en wrere. inehrm.gob.mx.

24 Estas investigaciones interesantes pueden consultarse en Rojas Garcíadueñas, José, Don Fosé Bernardo Couto, jurista diplomático y escritor, Xalapa, Universidad Veracruzana, 1964, pp. 97-127.

$25 \mathrm{El}$ cuento aparece publicado en Obras del doctor D. Fosé Bernardo Couto, México, Imprenta de Victoriano Agüeros, 1898, t. I, pp. 373-387. 
Este libro forma parte del acervo de la Biblioteca Jurídica Virtual del Instituto de Investigaciones Jurídicas de la UNAM

dose en el siglo XX, de tal suerte que son accesibles las ediciones hechas por el Fondo de Cultura Económica (1947, la segunda edición se hizo en el 2006) y el Consejo Nacional para la Cultura y las Artes (1995). En esta obra se describe la historia de la pintura en México mediante una conversación imaginaria que una mañana de 1860 sostiene José Bernardo Couto con su primo José Joaquín Pesado ${ }^{26}$ y con Pelegrín Clavé (director de la escuela de pintura de la Academia de San Carlos), en las galerías de la Academia. Los tres personajes recorren las galerías e intercambian comentarios sobre las fechas de creación de las obras, información relacionada con los autores de las pinturas, las técnicas empleadas en su elaboración y los lugares donde originalmente fueron exhibidas.

En la primera página del Diálogo, Couto explica a sus escuchas que la intención de formar la colección pictórica de la Academia de San Carlos fue "presentar, por medio de una serie de cuadros, la historia del arte en México. En esta sala esa historia no se lee, sino que ella misma va pasando delante de los ojos". ${ }^{27}$ Es

26 Un estudio importante sobre las relaciones de poder de las familias de Couto y Pesado se encuentra en Acle Aguirre, Andrea, "Amigos y aliados: José Bernardo Couto (1803-1862) y José Joaquín Pesado (1801-1861)", Historia Mexicana, México, vol. LXI, núm. 1, julio-septiembre de 2011, pp. 163-230.

27 Couto, José Bernardo, Diálogo sobre la historia de la pintura en México, México, Consejo Nacional para la Cultura y las Artes, 1995, p. 67. 
Este libro forma parte del acervo de la Biblioteca Jurídica Virtual del Instituto de Investigaciones Jurídicas de la UNAM

obvio que mediante este recurso literario el abogado Couto exaltaba el valor de la tarea que realizó al frente de la Academia de San Carlos, y procuró crear una fuente documental que sirviera a las generaciones posteriores para justipreciar el patrimonio pictórico de la nación.

Cuando todavía se encontraba en funciones la Pinacoteca Virreinal de San Diego (ubicada a un costado de la Alameda Central de la Ciudad de México), el Consejo Nacional para la Cultura y las Artes informaba, mediante folletos, que la colección de la Pinacoteca estaba constituida por 350 pinturas, realizadas en México durante los siglos XVI al XVIII y el primer cuarto del siglo XIX; y menciona la importante labor de rescate hecha por don José Bernardo Couto, misma que permitió preservar valiosos retablos conventuales que se pudieron perder por los trastornos que originó la implementación de las Leyes de Reforma. Recuérdese que entre estas leyes se encontraba la de nacionalización de los bienes eclesiásticos. Esta ley en su parte medular estableció lo siguiente:

Artículo 1o. Entran al dominio de la nación todos los bienes que el clero secular y regular ha estado administrando con diversos títulos, sea cual fuere la clase de predios, derechos y acciones en que consistan, el nombre y aplicación que hayan tenido. 
Este libro forma parte del acervo de la Biblioteca Jurídica Virtual del Instituto de Investigaciones Jurídicas de la UNAM

Artículo 10. Las imágenes, paramentos y vasos sagrados de las iglesias de los regulares suprimidos, se entregarán por formal inventario a los obispos diocesanos.

Artículo 12. Los libros, impresos, manuscritos, pinturas, antigüedades y demás objetos pertenecientes a las comunidades religiosas suprimidas, se aplicarán a los museos, liceos, bibliotecas y otros establecimientos públicos. ${ }^{28}$

José Bernardo Couto militó en los grupos conservadores y liberales del siglo XIX teniendo el papel protagónico que se ha enunciado en esta biografía, una muestra de la trascendencia de Couto en el mundo del siglo XIX mexicano es la incorporación del abogado como uno de los personajes de la novela clásica de la literatura mexicana Los bandidos de Río Frío, donde el jurista es presentado por Manuel Payno como una de las víctimas de la delincuencia de esos tiempos, mientras viajaba desde Orizaba con su primo Joaquín Pesado. ${ }^{29}$ También el escritor Guillermo Prieto inmortalizó a Couto a través de la obra Memorias de mis tiempos, en la cual se hace una descripción física y del carácter del jurista veracruzano de la cual agrego un fragmento:

28 La ley aparece publicada en wrwre.inehrm.gob.mx.

29 Payno, Manuel, Los bandidos de Río Frío, 26a. ed., México, Porrúa, 2011, pp. 362-366. 
Este libro forma parte del acervo de la Biblioteca Jurídica Virtual del Instituto de Investigaciones Jurídicas de la UNAM

Pequeño de cuerpo, de modales compasados y graves, frente convexa llena de bondad e inteligencia, ojos encapotados pero penetrantes, cabello como púas, retraído, silencioso, con pasos afectadamente largos, don Bernardo Couto, habría pasado como una persona vulgar si no se le hubiera escuchado en la tribuna...

Literato distinguido, conocedor como pocos de nuestra historia, jurisconsulto eminente, dado a conocer muy ventajosamente por el doctor Mora como hombre de la más alta importancia, Couto no se envanecía, y su trato era dulce y comedido.

$\mathrm{Su}$ intransigencia, y acaso cierto cambio en sus opiniones liberales, dependía de sus escrúpulos religiosos. ${ }^{30}$

\section{JOSÉ MARÍA LAFRAGUA}

Su nombre completo fue José María Franco de Paula Lafragua Ibarra. ${ }^{31}$ Nació el 2 de abril de 1813 en la ciudad de Puebla, Puebla y falleció el 15 de noviembre de 1875, en la Ciudad de México. Sus restos reposan en el Panteón de San Fernando. Lafragua realizó sus estudios en el colegio Carolino de Puebla entre 1824

30 Prieto, Guillermo, Memorias de mis tiempos, 3a. ed., México, Porrúa, 2004, pp. 327 y 328.

31 Según la fe de bautismo de este personaje, publicada en Quintana, José Miguel, Lafragua. Político y romántico, México, Academia Literaria, 1958, p. 75. 
Este libro forma parte del acervo de la Biblioteca Jurídica Virtual del Instituto de Investigaciones Jurídicas de la UNAM

y 1825. Un año después el joven Lafragua recibió una beca que le permitió terminar los cursos menores de griego, latinidad, historia universal, matemáticas, física, redacción y retórica. En 1829 ingresó al Colegio de Abogados de Puebla, titulándose en 1835.

El jurista poblano tuvo durante toda su vida una intensa participación en la esfera pública de México, toda vez que trabajó en los tres poderes federales, además de ser miembro de múltiples asociaciones literarias, políticas y científicas de su época, porque fue creador literario, periodista, bibliófilo y aficionado a los estudios sobre historia. Fue creador de normas jurídicas de enorme trascendencia para la consolidación del Estado mexicano, mismas que elaboró tanto como miembro del Poder Legislativo federal como del Ejecutivo (normas administrativas) en diferentes etapas del siglo XIX. Se destacó por sus afanes protectores al patrimonio documental de México (archivos y bibliotecas) y por su impulso al derecho de autor. Lafragua fue un político de tendencia liberal y defensor del sistema republicano. ${ }^{32}$

Dentro del Poder Legislativo, Lafragua formó parte del Congreso Constituyente como diputado por el de-

32 Para conocer a profundidad la participación de este jurisconsulto en la formación y desarrollo de la legislación cultural, véase Berrueco García, Adriana, Fosé María Lafragua precursor de la protección al patrimonio cultural, México, UNAM, Instituto de Investigaciones Jurídicas, 2013. 
Este libro forma parte del acervo de la Biblioteca Jurídica Virtual del Instituto de Investigaciones Jurídicas de la UNAM

partamento de Puebla, en 1842. En 1846 el jurista fue electo nuevamente diputado por Puebla al Congreso Constituyente de 1847. En 1848 se desempeñó como senador, en representación de su estado natal.

Como integrante del Poder Ejecutivo Federal creó importantes regulaciones jurídicas; durante la presidencia de Mariano Salas, en 1846, Lafragua fungió como ministro del Interior y Exterior, cargo en el cual elaboró el Reglamento Provisional de la Libertad de Imprenta (14 de noviembre), el Decreto sobre el establecimiento de una Biblioteca Nacional (30 de noviembre), el Decreto de Propiedad Literaria (3 de diciembre) y el Reglamento del Archivo General de la Nación (19 de noviembre).

En enero de 1857, en su calidad de ministro de Gobernación, Lafragua emitió la Ley Orgánica del Registro Civil y la Ley sobre Secularización de Cementerios, con lo cual el gobierno tomó bajo su control las importantes funciones que en ambos ramos tuvo el clero católico. ${ }^{33}$ En el régimen de Comonfort, el jurista Lafragua elaboró una importante normativa constitucional, el Estatuto Orgánico Provisional de la República Mexicana, destinada a regir como Constitución como resultado del triunfo de la Revolución de Ayutla, lo promulgó el presidente Comonfort en mayo

33 Galeana, Patricia, "El siglo XIX", en Galeana, Patricia (coord.), Los siglos de México, México, Nueva imagen, 1991, p. 214. 
Este libro forma parte del acervo de la Biblioteca Jurídica Virtual del Instituto de Investigaciones Jurídicas de la UNAM

de 1856 y estuvo vigente hasta la entrada en vigor de la Constitución de 1857 (el Congreso Constituyente ya se encontraba sesionando). Este Estatuto reconocía las garantías individuales (artículos 30-79), pero ordenaba que los gobernadores de los estados y distritos y los jefes políticos de los territorios fueran nombrados por el presidente de la República (artículo 114). ${ }^{34}$

El abogado Lafragua, fue un prolífico escritor realizó dos textos autobiográficos que no tuvo la intención de divulgarlos, pero por encontrarse entre los documentos legados por el jurista a la Biblioteca Nacional de México se les ha dado difusión por parte de diferentes instituciones públicas. La obra referente a sus experiencias en la esfera pública se le ha titulado Miscelánea política, misma que fue redactada en 1860 . Sin embargo, se publicó hasta 1943 por la Academia Mexicana de Historia. El otro texto, de corte totalmente íntimo, sobre la vida personal de su autor y la relación sentimental con Dolores Escalante, se llama Ecos del corazón, creado por Lafragua en 1863.

A petición del historiador Manuel Orozco y Berra, en 1854, el señor Lafragua realizó el artículo "Ciudad antigua de México", misma que fue incluida en el Dic-

34 El Estatuto Orgánico Provisional de la República Mexicana aparece publicado en op. cit., nota 12, pp. 400-421. Se recomienda la lectura de Valadés, Diego, "Reflexiones sobre el Estatuto Orgánico de 1856", Nueva gaceta bibliográfica, México, año 16, núm. 64, octubre-diciembre de 2013, pp. 63-68. 
Este libro forma parte del acervo de la Biblioteca Jurídica Virtual del Instituto de Investigaciones Jurídicas de la UNAM

cionario universal de historia y geografia. ${ }^{35}$ Entre los estudios biográficos elaborados por el jurista sobresalen Iturbide (1838) y Vicente Guerrero. Biografia (1853). Con anterioridad, en 1843, el abogado Lafragua fue designado por la Junta Patriótica para crear un discurso con motivo del aniversario de la consumación de la Independencia de México, mismo que se denomina Arenga cívica, publicado en la imprenta de Vicente García Torres, discurso que concluyó con la frase "Mexicanos: Dios salve a la República". ${ }^{36}$

En lo referente a las publicaciones periodísticas es de destacar que la carrera política de Lafragua dio inicio precisamente con su desempeño como redactor de la publicación masónica El imperio de la opinión, en 1835, posteriormente colaboró en el periódico $L a$ abeja poblana. Cuando el jurista se estableció en la Ciudad de México realizó publicaciones en los periódicos liberales el Monitor Republicano y El siglo XIX, así como en El estandarte nacional (partidarios del sistema federal) y La voz del pueblo.

35 Esta interesante investigación también fue publicada en Lafragua, José María y Orozco y Berra, Manuel, La Ciudad de México, México, Porrúa, 1998, Colección Sepan Cuántos, núm. 520, pp. 3-15.

36 Lafragua, José María, Arenga cívica, consultado en Discursos patrióticos de la consumación de la Independencia de México. 1821, colección Forge Denegre Vaught Peña, México, UNAM, Instituto de Investigaciones Jurídicas, 2014, t. I, pp. 195-218. 
Este libro forma parte del acervo de la Biblioteca Jurídica Virtual del Instituto de Investigaciones Jurídicas de la UNAM

El abogado Lafragua fue un gran aficionado al teatro y la literatura, en esa virtud fundó con Casimiro del Collado la publicación El apuntador, en 1841, en la que el jurista poblano difundió críticas literarias, artículos costumbristas y reseñas teatrales. ${ }^{37}$ Las piezas poéticas de Lafragua se dieron a conocer a través de El mosaico mexicano y El semanario de las señoritas mexicanas. En El museo popular publicó las traducciones que hizo de las obras de Lord Byron. El abogado tenía el anhelo de crear una identidad nacional en la literatura, y entendía que los mexicanos debían conocer los valores culturales de otras naciones para enriquecer su visión del mundo.

Don José María Lafragua fue integrante de la Academia de San Juan de Letrán y de la sociedad literaria conocida como "El ateneo mexicano" (fundada en 1840). Formó parte de la Academia de la Lengua (no la actual, sino se trata de la institución fundada o restablecida en 1854)..$^{38}$ Fue integrante de la Sociedad Mexicana de Geografía y Estadística, la cual presidió de 1868 a 1869.

37 Varios de los artículos de la autoría de Lafragua publicados en El apuntador se pueden consultar en Quintana, José Miguel, Lafragua. Político y romántico, México, Editorial Academia Literaria, 1958, pp. 243-304.

38 Cfr. Martínez, José Luis (ed.), Semblanzas de académicos. Antiguas, recientes, nuevas, México, Academia Mexicana de la LenguaFondo de Cultura Económica, 2004, p. 130. 
Este libro forma parte del acervo de la Biblioteca Jurídica Virtual del Instituto de Investigaciones Jurídicas de la UNAM

De 1867 a 1875 Lafragua se desempeñó como director de la Biblioteca Nacional de México. De 1872 a 1875 fue ministro del Exterior, en los gobiernos de Benito Juárez y Sebastián Lerdo de Tejada, en esta etapa estableció legaciones en Alemania, España, Francia y Guatemala; Lafragua formó parte de la comisión examinadora de límites fronterizos entre México y los Estados Unidos de Norteamérica, además hizo estudios sobre el conflicto de límites geográficos de nuestro país con Guatemala, pero no logró concluir este conflicto porque falleció en noviembre de $1875 .{ }^{39}$

Desde su niñez el señor Lafragua tuvo una notable inclinación a coleccionar impresos de diferentes temas, especialmente históricos, políticos y de arte. Con el tiempo formó una vastísima biblioteca integrada por libros, periódicos, revistas, folletos y proclamas políticas de México y el extranjero, aprovechó su estancia en Europa para adquirir valiosos libros sobre derecho, con los cuales apoyó los trabajos de las comisiones redactoras de los códigos civil, penal (Código de Martínez de Castro) y de procedimientos civiles federales, ya que formó parte de dichas comisiones en la década de los setenta del siglo XIX. A su fallecimiento el rico acervo documental de don José María Lafragua fue legado a la Biblioteca Nacional de México y al

39 Torre Rendón, Judith de la, "José María Lafragua Ibarra", Cancilleres de México siglo XIX, México, Secretaría de Relaciones Exteriores, 1992, pp. 262 у 270. 
Este libro forma parte del acervo de la Biblioteca Jurídica Virtual del Instituto de Investigaciones Jurídicas de la UNAM

Colegio Carolino de Puebla que hoy es la Benemérita Universidad Autónoma de Puebla. En 2006 la Colección Lafragua de la Biblioteca Nacional de México recibió el registro de la UNESCO como parte de la "Memoria del Mundo", la Colección está integrada por 1580 volúmenes que contienen más de 24 mil documentos, es la colección más consultada de la Biblioteca Nacional de México. ${ }^{40}$

Finalmente es de mencionarse que en la Galería de cancilleres mexicanos de la Secretaría de Relaciones Exteriores se encuentra un retrato de don José María Lafragua, pintado por Germán Gedovius. La memoria del insigne jurista continúa siendo honrada en diferentes foros académicos, de tal suerte que en octubre de 2013 la Biblioteca Nacional de México, el Instituto de Investigaciones Bibliográficas de la UNAM y la Academia Mexicana de la Lengua organizaron el homenaje a don José María Lafragua en el bicentenario de su nacimiento (1813-2013), en el cual participaron Adriana Berrueco, Guadalupe Curiel Defossè, Luis Olivera, Vicente Quirarte y Diego Valadés.

\section{JOSÉ MARÍA LUIS MORA}

Nació en octubre de 1794 en Chamacuero, Guanajuato, y falleció en París, Francia el 14 de julio de 
Este libro forma parte del acervo de la Biblioteca Jurídica Virtual del Instituto de Investigaciones Jurídicas de la UNAM

1850. Se ordenó sacerdote en la segunda década del siglo XIX y obtuvo el grado de doctor en teología. ${ }^{41}$ En el Estado de México, en marzo de 1827, obtuvo el título de abogado presentando la disertación sobre ¿Cuáles son las ventajas que han resultado al Estado de méjico de las variaciones hechas en su Constitución, asi sobre el orden de los juicios como el de los tribunales? ${ }^{32}$ En 1822 Mora se incorporó como miembro de la diputación provincial. En el Primer Imperio atacó a Agustín de Iturbide por lo que fue perseguido y se escondió en un convento. En cuestiones políticas estuvo afiliado al partido escocés (logia masónica) por ello, al triunfo de los yorquinos, en 1827, se retiró temporalmente de la política y se dedicó a escribir.

A lo largo de su vida, Mora ejerció el periodismo en diferentes medios, de 1820 a 1821 se hizo cargo de la redacción del Semanario político y literario, en él publicó, los artículos "Discurso sobre la independencia del Imperio mejicano" y "La suprema autoridad civil no es ilimitada", en la introducción que publicó, en el primer número del semanario, Mora ofrece abordar con imparcialidad los temas relacionados con la política, de igual forma, exponía que el contenido de

41 Cano Andaluz, Aurora, Biografias para niños. Fosé María Luis Mora, México, Instituto de Estudios Históricos de las Revoluciones de México, 1987, pp. 28-30.

42 Publicado en Mora, José María Luis, Obras sueltas, París, Librería de Rosa, 1837, pp. 112-121. 
Este libro forma parte del acervo de la Biblioteca Jurídica Virtual del Instituto de Investigaciones Jurídicas de la UNAM

la publicación sería útil a un amplio espectro de lectores. En 1823 el doctor Mora escribió en los periódicos masónicos El Sol y El Águila Mexicana. Durante la presidencia de Guadalupe Victoria, Mora publicó la primera época de El Observador de la República Mexicana (semanario), en él también participaron Francisco M. Sánchez de Tagle y Florentino Martínez, la publicación circuló de 1827 a 1828. En El Observador el doctor Mora difundió el estudio, que he mencionado, con el cual obtuvo el título de abogado, también sobresalen una nota necrológica a Fray Servando Teresa de Mier y un artículo sobre la Sociedad de la Biblia.

En 1837 se difundió la segunda época de El Observador, en ella Mora se ocupa de compartir reflexiones con sus contemporáneos sobre problemas sociales, políticos y jurídicos, entre estos últimos se insertan los artículos titulados "Discurso sobre la necesidad de que sea efectiva la independencia del poder judicial", y "Discurso sobre la necesidad de variar nuestra Constitución en cuanto a la época, duración y periodo de las elecciones de presidente, vice-presidente, diputados y senadores". En lo referente a padecimientos sociales Mora muestra su preocupación por los altos índices delincuenciales que se presentaban en nuestro país, temática abordada en Reflexiones sobre la situación deplorable del Estado de México. Sobre política y gobernabilidad Mora publicó Discurso sobre las sociedades secretas y De los medios para precaver las revoluciones. 
Este libro forma parte del acervo de la Biblioteca Jurídica Virtual del Instituto de Investigaciones Jurídicas de la UNAM

José María Luis Mora tuvo un papel trascendente en la conformación del Estado de México, toda vez que fue integrante del Congreso constituyente de dicha entidad en 1824, y en 1827 presidió ese cuerpo colegiado, mismo que creó la Constitución del Estado de México. ${ }^{43}$ Durante 1831 escribió el Discurso sobre la naturaleza y aplicación de las rentas y los bienes eclesiásticos y el Catecismo político de la Federación Mexicana. En 1832 Mora fue nombrado diputado federal por el estado de Guanajuato. ${ }^{44}$

En 1833 Antonio López de Santa Anna asumió la Presidencia de la República, quedando don Valentín Gómez Farías como vicepresidente, por diferentes trastornos políticos Santa Anna dejó las funciones de la presidencia en manos de Gómez Farías, durante un año, ${ }^{45}$ quien se dedicó a realizar una profunda trans-

43 Véase el estudio publicado interesante por Macedo Jaimes, Graciela, "Breve estudio de las Constituciones del Estado de México", Anuario Mexicano de Historia del Derecho, México, vol. VIII, 1996, pp. 257-275.

44 Arnáiz y Freg, Arturo (prolonguista), "Cronología", en Fosé María Luis Mora. Ensayos, ideas y retratos, México, UNAM, 2014, Biblioteca del Estudiante Universitario, núm. 25.

45 Sobre el movimiento de rebelión que tuvo por lema "religión y fueros" combatido por Santa Anna y las reformas secularizantes véase Vázquez, Josefina Zoraida, "El establecimiento del México independiente (1821-1848)", en Wobeser Von, Gisela, Historia de México, México, Presidencia de la República-Fondo de Cultura Económica, 2010, p. 170. 
Este libro forma parte del acervo de la Biblioteca Jurídica Virtual del Instituto de Investigaciones Jurídicas de la UNAM

formación de la vida pública para implementar principios liberales y el laicismo a efecto de rescatar a México de la postración que padecía, entre otras causas por la ignorancia y el fanatismo religioso del pueblo, por la carencia de desarrollo de la ciencia y por la hegemonía económica de la Iglesia católica. Tan radicales fueron las medidas del médico jalisciense que diferentes historiadores mencionan su periodo de gobierno como el de la Primera Reforma (que antecedió a la del presidente Juárez). En esta etapa, el doctor Mora trabajó estrechamente con Gómez Farías e impulsó una política liberal en los rubros de la educación y la cultura. Mora propuso la clausura de la Universidad y la creación de una Biblioteca Nacional, ideas instrumentadas por Valentín Gómez Farías. Es importante hacer notar que aunque Mora se constituyó como un influyente asesor del vicepresidente, niega que éste aplicara las ideas del sacerdote sin mayor ponderación. Mora afirmó en una breve autobiografía que la instrumentación de la política educativa y otras medidas de control al clero fueron consecuencia de que Valentín Gómez Farías tenía opiniones coincidentes con su asesor, ${ }^{46}$ pero esta afirmación parece una muestra de modestia del doctor Mora y una expresión de respeto a la figura presidencial, pues José María Luis Mora consideraba a la

46 Mora, José María Luis, "Semblanza autobiográfica", cit., nota 44, p. 173. 
Este libro forma parte del acervo de la Biblioteca Jurídica Virtual del Instituto de Investigaciones Jurídicas de la UNAM

educación como el cimiento de la gran edificación que sería la República mexicana, de ello dan cuenta diversas reflexiones que plasmó en el papel, de las cuales expongo las más destacadas.

Si la educación es el monopolio de ciertas clases y de un número más o menos reducido de familias, no hay que esperar ni pensar en sistema representativo, menos republicano, y todavía menos popular. La oligarquía es el régimen inevitable de un pueblo ignorante en el cual no hay o no puede haber monarca: esta forma administrativa será ejercida por clases o por familias, según que la instrucción y el predominio se halle en las urnas o en otras, pero la masa será inevitablemente sacrificada a ellas, como lo fue por siglos en Venecia. ${ }^{47}$

De sus Pensamientos sueltos sobre educación pública son de recordarse los que se refieren a la necesidad de educar a la población para que cumpla las leyes y tenga viabilidad la República, a lo cual Mora se refirió en los siguientes términos.

Para entender la constitución y las leyes es indispensable saber leer; para pesar las razones alegadas en la tribuna nacional, sea para la formación o reforma de la una y las otras, se requiere tener algunos conocimientos generales, a lo menos haber adquirido algu-

Ibidem, pp. 129 y 130. 
Este libro forma parte del acervo de la Biblioteca Jurídica Virtual del Instituto de Investigaciones Jurídicas de la UNAM

nas reglas en el arte de pensar, para sujetar el juicio; de lo contrario, no es posible que las reglas morales que deben servir de guía al hombre social, tenga todo el buen resultado que desean los filósofos y los legisladores. ${ }^{48}$

Contando con Mora como consejero ${ }^{49}$ el vicepresidente Gómez Farías hizo posible que el Congreso mexicano emitiera la primera gran reforma educativa de la nueva nación. A finales de 1833 se publicaron varias disposiciones jurídicas que limitaron el predominio de la Iglesia católica en dicha actividad, la primera de ellas estableció la autorización al gobierno para arreglar la enseñanza pública en todos sus ramos, en el distrito y territorios federales. Al suprimirse la Universidad de México se creó en su lugar la Dirección General de Instrucción Pública para el distrito y territorios de la Federación encargada de todos los establecimientos públicos de enseñanza, de los depó-

\section{Ibidem, p. 80}

49 En el archivo personal de Mora se hallan los nombramientos recibidos en este gobierno como vocal de la Junta encargada de proponer al Supremo Gobierno un plan general de estudios (20 de septiembre de 1833), y como director de Ciencias Ideológicas y Humanidades (26 de octubre de 1833). Véase versión digital del Archivo de José María Luis Mora de la Colección latinoamericana Nettie Lee Benson de la Universidad de Texas en Austin, sección correspondencia de julio de 1833 a 1838, en http://lanic.utexas.edu/ proyect/mora, consultado en noviembre de 2014. 
Este libro forma parte del acervo de la Biblioteca Jurídica Virtual del Instituto de Investigaciones Jurídicas de la UNAM

sitos de los monumentos de artes, antigüedades e historia natural y los fondos públicos designados para la enseñanza. También se determinó que los grados de doctor fueron conferidos en ceremonias públicas por la Dirección y que ésta expidiera los títulos correspondientes. Se estableció una figura similar a los libros de texto gratuito que en la actualidad proporciona el Estado mexicano (decreto del 19 de octubre de 1833). ${ }^{50}$ Por otra parte, el conjunto de leyes reformistas también se ocupó de suprimir la obligación jurídica de pagar diezmos y el cumplimiento de los votos monás-

50 Las leyes fueron: Decreto por el que se autoriza al gobierno para arreglar la enseñanza pública en todos sus ramos, en el distrito y territorios; Decreto por el que se suprime la Universidad y se establece la Dirección General de Instrucción Pública para el Distrito y territorios de la Federación (23 de octubre de 1833); Ley para la organización de una Biblioteca Nacional; Regulación de la Dirección de Teatro; Decreto para el establecimiento de una escuela normal para los que se destinen a la enseñanza primaria; Decreto sobre la Escuela Primaria de Letras creada en el establecimiento de Estudios Ideológicos disponiendo que la escuela se destine exclusivamente a la enseñanza de artesanos adultos, maestros, oficiales y aprendices; Decreto sobre el personal docente de la carrera de medicina; Decreto sobre exámenes para obtener el título de agrimensor; Decreto estableciendo las cátedras de dibujo y de delineación en el tercer Establecimiento de Instrucción Pública; Decreto con reformas a la ley de 23 de octubre de 1833 sobre las carreras de medicina y ciencias físicas. Estas disposiciones aparecen publicadas en http://wrwe.sep.gob.mx/work, se consultaron el 1o. de septiembre de 2015 . 
Este libro forma parte del acervo de la Biblioteca Jurídica Virtual del Instituto de Investigaciones Jurídicas de la UNAM

ticos. Fue en esta breve temporada de florecimiento de la cultura cuando se fundó la Sociedad Mexicana de Geografía y Estadística (18 de abril de 1833), siendo ésta la primera sociedad científica de América, misma que contó con gran apoyo del doctor Valentín Gómez Farías. Respecto a las ideas del abogado Mora sobre la regulación de los bienes inmuebles eclesiásticos, se hace notar que, en 1833 era sumamente radical la normatividad propuesta tanto por Mora como por Lorenzo de Zavala, quienes propugnaban por la expropiación de dichos bienes. ${ }^{51}$

Mora salió de México en 1834 por la política conservadora de Santa Anna cuando éste volvió a asumir la Presidencia de la República y suspendió las reformas decretadas en noviembre de 1833, a excepción de lo referente a pago de diezmos. José María Luis Mora radicó en Estados Unidos de Norteamérica y después partió a Francia, donde padeció vicisitudes económicas de las cuales se liberó gracias a que, en 1846, por intervención de José Bernardo Couto, fue incorporado a la Legación de México en París. En 1847 recibió el nombramiento de ministro plenipotenciario de México ante la reina Victoria de Inglaterra, en esta etapa, la tuberculosis que padecía Mora se recrudeció y tuvo que volver a París. Precisamente en Francia Mora pu-

51 El tema es tratado con amplitud en Fernández Ruiz, Jorge, fuárez y sus contemporáneos, México, UNAM, Instituto de Investigaciones Jurídicas, 2006, pp. 192 y 193. 
Este libro forma parte del acervo de la Biblioteca Jurídica Virtual del Instituto de Investigaciones Jurídicas de la UNAM

blicó su famoso estudio México y sus revoluciones (1836) y Obras sueltas (1837).

México y sus revoluciones es un trabajo de corte histórico muy bien fundamentado en estadísticas y otros datos obtenidos por Mora, aborda en el primer tomo aspectos relevantes de la Constitución de 1824, de los tribunales que operaban en la época (1835); en la advertencia preliminar el doctor Mora hace una crítica a la mayoría de obras históricas que referentes a México se habían publicado sin contar con fuentes serias de información, Mora opinaba que el único libro sobre el tema que merecía confianza y respeto era el Ensayo politico sobre la Nueva España del barón de Humboldt, entonces Mora buscaba con su México y sus revoluciones crear un texto actualizado que procurara una imagen certera a los extranjeros de la historia y realidad decimonónica de México. ${ }^{52}$ De la lectura de la advertencia preliminar y del resto del primer tomo se desprende un interés propio de un diplomático de forjar una imagen positiva de su país en el exterior, pues dedica unas páginas a describir a las mujeres mexicanas como interesadas en acudir a conciertos musicales para escuchar las composiciones de Mozart y Bellini, también afirmaba Mora que entre las clases acomodadas era infaltable en el mobiliario casero un piano

52 Mora, José María Luis, México y sus revoluciones, 4a. ed., México, Porrúa, 1986, t. I, p. 4. 
Este libro forma parte del acervo de la Biblioteca Jurídica Virtual del Instituto de Investigaciones Jurídicas de la UNAM

para que las mujeres se ejercitaran en el canto, éstas también daban singular interés al uso de ropa elegante. ${ }^{53}$ Era normal que el doctor Mora se ocupara de estas cuestiones dado a que él pertenecía a la clase acomodada de la Nueva España, pero esta condición no le impidió dejar registrada la inmensa injusticia que la Corona Española y el clero le propinó a los naturales de América, aspectos que se hallan en el apartado $G o^{-}$ bierno de los indios. ${ }^{54}$

Falleció en París, en 1850, habiendo procreado tres hijos con una mujer inglesa (Elisa Hoy), información que consta en una carta que la empleada doméstica de Mora envió al abogado José Bernardo Couto (fechada el 26 de febrero de 1851), con la finalidad de que se les otorgara alguna herencia a los niños. ${ }^{55}$ Los restos mortales del abogado y sacerdote José María Luis Mora fueron sepultados en Francia, y en 1963 se trasladaron a México para ser depositados en la Rotonda de las Personas Ilustres.

Las ideas de tan distinguido abogado han seguido siendo objeto de análisis desde diferentes perspecti-

\section{Ibidem, pp. 123-127.}

54 Ibidem, pp. 168-184.

55 Briseño Senosiain, Lillian, "José María Luis Mora, del sueño al duelo", en Clark de Lara, Belem y Speckman Guerra, Elisa (eds.), La república de las letras. Asomos a la cultura escrita del México decimonónico, México, UNAM, Coordinación de Humanidades, 2005, vol. III, p. 90. 
Este libro forma parte del acervo de la Biblioteca Jurídica Virtual del Instituto de Investigaciones Jurídicas de la UNAM

vas, por ejemplo, en 1950 don Jesús Silva Herzog realizó un estudio denominado El doctor Mora, economista. ${ }^{56}$ Por su parte, don Genaro Fernández Mac Gregor publicó un estudio introductorio sobre la obra y el pensamiento de Mora que precede a una selección de algunos de sus artículos. ${ }^{57}$ En 1997 el Fondo de Cultura Económica publicó El carácter de los mexicanos (un fragmento de México y sus revoluciones) en la colección Fondo 2000, que es una selección de los grandes temas y los grandes autores de la cultura universal. Desde 1968 la Universidad de Yale publicó en inglés el libro El liberalismo mexicano en la época de Mora, que ha sido traducido y editado en español desde 1972 teniendo quince reimpresiones. ${ }^{58}$ En septiembre de 1981 el gobierno federal decretó la creación del Instituto de Investigaciones Dr. José María Luis Mora, institución que tiene como misión principal realizar investigación en los campos de la historia y las ciencias sociales, e impartir enseñanza en el nivel de posgrado para la formación de recursos humanos en las áreas mencionadas. Este Instituto tiene su sede en la Ciudad de México, en una casa que perteneció a don Valentín Gómez Fa-

56 Silva Herzog, Jesús, El doctor Mora, economista, en wrerce.colegionacional.org.mx/SACSCM, consultado en diciembre de 2014.

57 Fernández Mac Gregor, Genaro, El doctor Mora redivivo (selección de sus obras), México, Botas, 1938.

58 Hale A., Charles, El liberalismo mexicano en la época de Mora, México, Siglo XXI Editores, 2009. 
Este libro forma parte del acervo de la Biblioteca Jurídica Virtual del Instituto de Investigaciones Jurídicas de la UNAM

rías. ${ }^{59}$ En los considerandos del decreto de creación (como organismo descentralizado de la administración pública federal) el presidente de la República especificó:

Es conveniente recordar con el nombre de este Instituto al doctor José María Luis Mora, quien fuera precursor del liberalismo mexicano, en el inicio de la vida independiente del país y formador de las generaciones que posteriormente forjaron la Reforma en México. ${ }^{60}$

\section{MANUEL OROZCO Y BERRA}

Nació en la Ciudad de México el 8 de junio de 1816 y falleció en la misma ciudad el 27 de enero de 1881 . En 1834 obtuvo el título de ingeniero topógrafo. ${ }^{61}$ Posteriormente realizó estudios jurídicos y obtuvo el título de abogado en el Seminario Palafoxiano de Puebla, en 1847. ${ }^{62}$ En diferentes etapas de su vida impartió las cá-

59 Véase http://mora.edu.mx, consultada en septiembre de 2015.

60 Decreto por el que se crea el Instituto de Investigaciones Dr. José María Luis Mora, como organismo público descentralizado, México, Diario Oficial de la Federación, 30 de septiembre de 1981.

61 Véase Cronología de Manuel Orozco y Berra, en wrere.inehrm.gob. $m x / p d f /$ documento_orozcoberra1.

62 Escobedo Rojas, Alejandro G., "El Seminario Palafoxiano de la Puebla de los Ángeles: su mundo jurídico en los albores del Estado mexicano", en Cruz Barney, Oscar et al. (coords.), Los abo- 
Este libro forma parte del acervo de la Biblioteca Jurídica Virtual del Instituto de Investigaciones Jurídicas de la UNAM

tedras de historia e historia de México en el Colegio Militar, la Escuela de Minería y el Colegio de las Vizcaínas.

Don Francisco Sosa menciona que Orozco y Berra realizó diversas actividades públicas en el estado de Puebla a finales de la cuarta década e inicios de la quinta década del siglo XIX, entre ellas fue de suma importancia la formación de la estadística militar y el asesoramiento al juzgado de Tlaxcala. En dicho estado Manuel Orozco inició sus primeros ensayos literarios, mismos que se publicaron en los periódicos locales El Porvenir y La Libertad. En el fatídico año 1846 (por la invasión norteamericana a México), don Manuel Orozco y Berra fue elegido para redactar y leer en Puebla una oración cívica con motivo del inicio de la Guerra de Independencia. ${ }^{63}$ En 1851 el topógrafo y abogado viajó a la Ciudad de México para atender un negocio jurídico de Antonio López de Santa Anna; en 1852 don José Fernando Ramírez lo designó responsable de la sección de registros del Archivo General de la Nación, de cuya dirección se hizo cargo posteriormente. ${ }^{64}$

gados y la formación del Estado mexicano, México, UNAM, Instituto de Investigaciones Jurídicas, 2013, p. 106.

63 El discurso aparece publicado en Denegre Vauht Alcocer, Jorge Ramiro (comp.), Dos siglos de discursos patrióticos. Colección Denegre Vaught Peña, México, UNAM, Instituto de Investigaciones Jurídicas, 2011, pp. 451-462.

64 Sosa, Francisco, Biografias de mexicanos distinguidos, México, Porrúa, 2006, pp. 566-577. 
Este libro forma parte del acervo de la Biblioteca Jurídica Virtual del Instituto de Investigaciones Jurídicas de la UNAM

En la presidencia de Ignacio Comonfort fue oficial mayor del Ministerio de Fomento (1855-1857). En 1863 el presidente Benito Juárez lo nombró ministro de la Suprema Corte de Justicia de la Nación. De 1864 a 1867, por designación del emperador Maximiliano de Habsburgo, ejerció el cargo de conservador (director) en el área de Historia del Museo Nacional (denominado Museo Público de Historia Natural, Arqueología e Historia, hoy Museo Nacional de Antropología e Historia). ${ }^{65}$ En esta etapa, concretamente en 1867, dio a la imprenta la Memoria para el plano de la Ciudad de México, formada por el propio Orozco a petición del Ministerio de Fomento (encabezado por Joaquín de Mier y Terán).66 Por la colaboración prestada al emperador Maximiliano, Orozco y Berra estuvo preso algunos años, al restaurarse la República. ${ }^{67}$

Formó parte de importantes asociaciones y organismos culturales como "El Ateneo mexicano" (1841), "La Sociedad de Geografía y Estadística" (1861), y la "Academia de Ciencias y Literatura" (1870). También recibió la distinción de pertenecer a la Academia Mexicana de la Lengua, como miembro de número,

65 Lozada, Guadalupe, "Un gran museo para el México antiguo", Relatos e historias de México, México, núm. 71, julio de 2014, pp. 19-22.

66 Orozco y Berra, Manuel, Memoria para el plano de la Ciudad de México, México, Imprenta de Santiago White, 1867.

67 Sosa, Francisco, op. cit., nota 64, p. 570. 
Este libro forma parte del acervo de la Biblioteca Jurídica Virtual del Instituto de Investigaciones Jurídicas de la UNAM

ingresando en 1875. En 1877 se le designó miembro de honor de la Società Geografica Italiana.

Manuel Orozco y Berra se distinguió como un prolífico autor de textos sobre humanidades y ciencias naturales, entre los enormes méritos que poseen las obras escritas por este autor, sobresale que tienen por sustento fuentes directas de información obtenidas en los archivos y bibliotecas antiguas de México, fuentes que incluso paleografió personalmente el propio Orozco y Berra.

El abogado y topógrafo se hizo cargo de la coordinación del Diccionario universal de historia y geografia ${ }^{68}$ mismo que contiene un apéndice sobre México, en el cual escribieron los intelectuales más relevantes de la época, se publicó de 1853 a 1856 en la Ciudad de México. Esta obra trascendente cuenta con trabajos de Lucas Alamán, Joaquín García Icazbalceta, José María Lafragua, José Bernardo Couto, Miguel Lerdo de Tejada, Manuel Payno, Guillermo Prieto, José Fernando Ramírez, José María Roa Bárcena, Justo Sierra

68 El nombre completo de esta obra es: Diccionario universal de historia y geografia, obra dada a luz en España por una sociedad de literatos distinguidos, refundida y aumentada considerablemente para su publicación en México con noticias históricas, geográficas, estadísticas y biográficas sobre las Américas en general y especialmente sobre la República Mexicana, véase PiSuñer Llorens, Antonia (coord.), "Estudio preliminar", Catálogo de los artículos sobre México en el Diccionario universal de historia y de geografia, México, UNAM, Facultad de Filosofía y Letras, 1997, p. VII. 
Este libro forma parte del acervo de la Biblioteca Jurídica Virtual del Instituto de Investigaciones Jurídicas de la UNAM

O’Reilly, Joaquín Velázquez de León, Francisco Zarco y del propio Manuel Orozco y Berra. La obra se fue publicando por entregas semanales a los suscriptores que habían pagado su derecho a recibir el diccionario, tuvo como editores a José María Andrade y Felipe Escalante.

Como autor de artículos del diccionario, Orozco y Berra demostró un profundo conocimiento de los elementos constitutivos de la cultura mexicana, menciono a continuación solamente los títulos de las colaboraciones más representativas de Orozco en esta monumental obra: Apaches, Cholula (pirámide de), Colonias militares, Conjuración del Marqués del Valle (1565-1568), Itinerario del ejército español en la conquista de México, Medidas y pesos en la República Mexicana, Moneda en México, Negros (conjuración de los); semblanzas biográficas de Miguel Hidalgo y Costilla, José María Morelos y Pavón, Mariano Matamoros, Miguel Cabrera y Valerio Trujano. ${ }^{69}$

En los temas de historia, Manuel Orozco y Berra escribió, en 1853, Noticia histórica de la conjuración del Marqués del Valle, trabajo que se basó en la transcripción paleográfica del expediente legal de los sujetos implicados en la conjura. En 1871 publicó la Cronología

69 Los artículos mencionados aparecen en México en el Diccionario universal de historia y geografia, La contribución de Orozco y Berra, México, UNAM, Coordinación de Humanidades, 2004, vol. III. 
Este libro forma parte del acervo de la Biblioteca Jurídica Virtual del Instituto de Investigaciones Jurídicas de la UNAM

mexicana y la obra magna de este autor, denominada Historia antigua y de la conquista de México tuvo su primera edición en cuatro volúmenes, entre 1880 y 1881, misma que se reeditó en 1960 bajo la dirección de Ángel María Garibay. No se debe dejar de mencionar que entre las contribuciones de Manuel Orozco también se cuenta la transcripción y publicación de las Actas del Cabildo de la Ciudad de México del siglo XVI. ${ }^{70}$ Las obras históricas de este intelectual han sido analizadas por otros estudiosos de dicha disciplina humanista, mismos que han resaltado una innovación en la escuela de interpretación de nuestro pasado, pues Orozco y Berra buscó una posición más equilibrada para observar las culturas nativas de México y las transformaciones originadas por la dominación española. ${ }^{71}$

En 1864 Orozco y Berra vio publicada su Memoria para la carta hidrográfica del Valle de México, misma que fue creada por acuerdo de la Sociedad Mexicana de Geografía y Estadística, ${ }^{72}$ y en el mismo año la Geografía de las lenguas y carta etnográfica de México. En 1871 publicó Materiales para una cartografia mexicana, y en 1881 Apuntes para la historia de la geografía en México.

70 Torre Villar, Ernesto de la, op. cit., nota 35, p. LIII.

71 Un ejemplo de estudios recientes de la obra Orozco y Berra es Krauze, Enrique, La presencia del pasado, México, Tusquets, 2005.

72 Orozco y Berra, Manuel, Memoria para la carta hidrográfica del Valle de México, México, Imprenta de A. Boix, 1864. 
Este libro forma parte del acervo de la Biblioteca Jurídica Virtual del Instituto de Investigaciones Jurídicas de la UNAM

La protección del patrimonio documental de México fue una trascendente faceta de la vida profesional de Manuel Orozco y Berra, quien en compañía de sus maestros y amigos José Fernando Ramírez y Joaquín García Icazbalceta salvó de la destrucción total las colecciones de los conventos de Santo Domingo y San Francisco en la época de la nacionalización de bienes eclesiásticos. ${ }^{73}$ En el ámbito de la geografía se considera que los estudios de Orozco, en especial la Carta general del Imperio (encargada por Maximiliano), son una gran aportación para modernizar dicha disciplina en México; es una importante contribución para lo que hoy llamamos ordenamiento territorial. ${ }^{74}$

Sus aportaciones a la cultura de México han sido reconocidas de diferentes maneras en México y Latinoamérica, por ello las mapotecas del Instituto Panamericano de Geografía e Historia (organismo especializado de la Organización de los Estados Americanos $)^{75}$ y la de la Secretaría de Agricultura, Ganadería, Desarrollo Rural, Pesca y Alimentación de México llevan el nombre del ilustre abogado e historiador. En épo-

73 Torre Villar, Ernesto de la, op. cit., nota 35, p. LII.

74 Véase Contreras Servín, Carlos, "Antecedentes históricos del ordenamiento territorial en México: la obra de Manuel Orozco y Berra", Boletín de los Sistemas Nacionales Estadístico y de Información Geográfica, México, vol. 1, núm. 2, septiembre-diciembre de 2005, pp. 82-94.

75 Véase http://wrerc.ipgh.org/noticias/2011/Mapoteca. 
Este libro forma parte del acervo de la Biblioteca Jurídica Virtual del Instituto de Investigaciones Jurídicas de la UNAM

cas recientes se ha procedido a restaurar la documentación y el edificio que resguarda el Archivo Manuel Orozco y Berra, a cargo del Servicio de Información Agroalimentaria y Pesquera (SIAP), pues su colección está catalogada como el mayor acervo cartográfico de México y el más grande de América Latina, es la colección más importante de mapas y fotografías de los siglos XVII-XIX de México, estando conformada por cerca de 100 mil documentos. ${ }^{76}$

Finalmente ha de mencionarse que don José Rogelio Álvarez tomó como tema de su discurso de ingreso a la Academia Mexicana de la Lengua la magna compilación realizada por Orozco, el discurso se tituló $E l$ diccionario universal de Orozco y Berra, pieza literaria que se pronunció el 20 de febrero de 1992. ${ }^{77}$

76 Talavera, Juan Carlos, "Salvan acervo mayor, Archivo Manuel Orozco y Berra", Excélsior, México, 10 de junio de 2015.

77 Álvarez, José Rogelio, El diccionario universal de Orozco y Berra. Discurso de ingreso a la Academia Mexicana de la Lengua, 20 de febrero de 1992, México, UNAM-Coordinación de Difusión Cultural- Academia Mexicana de la Lengua, 2010. 
Este libro forma parte del acervo de la Biblioteca Jurídica Virtual del Instituto de Investigaciones Jurídicas de la UNAM

\section{Gapítulo SEgundo ABOGADOS DE LA ERA POSREVOLUCIONARIA}

\section{CONTEXTO HISTÓRICO POLÍTICO}

Al finalizar la primera década del siglo XX México vivió un estremecedor cataclismo político, social, económico y jurídico. Las estructuras caducas del Porfiriato dejaron una nación marcada por las desigualdades sociales. El autoritarismo del régimen político se tornó insoportable, en 1911 Porfirio Díaz renunció al cargo de presidente de la República y lo sustituyó Francisco I. Madero por medios democráticos. En 1913 Victoriano Huerta da un golpe de Estado al gobierno maderista orillando a un levantamiento armado que se conoce como Revolución Constitucionalista. En esta etapa existen dos gobiernos, el de Huerta y el de los revolucionarios, en julio de 1914 Venustiano Carranza es reconocido como jefe de los constitucionalistas, las discrepancias existentes entre las facciones revolucionarias tratan de subsanarse con la Convención de Aguascalientes; el 15 de julio de 1914 Victoriano 
Este libro forma parte del acervo de la Biblioteca Jurídica Virtual del Instituto de Investigaciones Jurídicas de la UNAM

Huerta renuncia a la presidencia. En medio de la desazón política México padeció nuevamente la intervención en su territorio de las tropas estadounidenses en 1914, que termina en noviembre de dicho año con la entrega del puerto de Veracruz al gobernador Cándido Aguilar, representante de los constitucionalistas. En 1916 Carranza emite la convocatoria para la elección de diputados que reformarían la Constitución de 1857. El 5 de febrero de 1917 se promulga una nueva Constitución.

El mejor fruto de la Revolución constitucionalista fue la nueva Constitución Política de los Estados Unidos Mexicanos que pretendía reorganizar la economía y limitar las desigualdades con un conjunto de garantías sociales que normaban las relaciones de trabajo, el sistema de tenencia de las tierras y que establecía el derecho a la educación, era la primera Constitución político social del mundo. La instrumentación de esta innovadora normatividad se fue desarrollando en medio de convulsiones políticas porque las facciones revolucionarias lucharon por el control del poder político. En 1920 fue asesinado Venustiano Carranza, siendo sucedido a la Presidencia de la República por Adolfo de la Huerta, cuyo sucesor Álvaro Obregón efectuaría un conjunto de acciones para instrumentar el proyecto revolucionario, entre ellas se encontró la creación de la Secretaría de Educación Pública que quedó a cargo del abogado oaxaqueño José Vasconce- 
Este libro forma parte del acervo de la Biblioteca Jurídica Virtual del Instituto de Investigaciones Jurídicas de la UNAM

los, quien promovería una intensa campaña de alfabetización y procuró un vasto apoyo al desarrollo de las artes plásticas cuyo notabilísimo resultado fue el movimiento muralístico mexicano. Las políticas educativas de Vasconcelos han ejercido una notable influencia en México hasta nuestros días.

En 1929 la Universidad Nacional de México alcanzó su autonomía y paulatinamente fue adquiriendo un sitio privilegiado como institución señera de las actividades docentes y de investigación de nuestro país. En esta Universidad adquirieron su formación académica los principales intelectuales mexicanos que han forjado las instituciones públicas y han participado en labores legislativas y diplomáticas. Para el tema que nos ocupa es un factor relevante que de la Facultad de Derecho (antes Escuela Nacional de Jurisprudencia) de la Universidad Nacional Autónoma de México (UNAM) se escindió el estudio de las ciencias sociales en 1951, con la formación de la Escuela de Ciencias Políticas y Sociales (actualmente Facultad). La creación de esta entidad fue propuesta e instrumentada por abogados, uno de ellos, don Emilio O. Rabasa, quien es biografiado en este capítulo. Ambas facultades mantienen lazos estrechos por la afinidad de sus objetos de estudio y por el hecho de que tradicionalmente los profesionales del derecho han sido quienes ocupan los cargos más relevantes en las funciones públicas, por ello el análisis de la política aún a finales del siglo XX 
Este libro forma parte del acervo de la Biblioteca Jurídica Virtual del Instituto de Investigaciones Jurídicas de la UNAM

continuó siendo cultivado por abogados como Luis Javier Garrido, quien fue un docente reconocido de la Facultad de Ciencias Políticas y Sociales donde también coadyuvó a la formación de científicos sociales.

A partir de la década de los cuarenta en la UNAM fueron creados diversos institutos para el estudio profundo de las humanidades y las ciencias sociales, en varios de ellos realizaron sus labores académicas algunos de los personajes cuyas biografías dan sustento a este capítulo, específicamente en los institutos de Investigaciones Jurídicas, Investigaciones Bibliográficas, Investigaciones Filológicas, Investigaciones Históricas e Investigaciones Sociales.

En un ámbito más amplio, que es el nacional, se ha de subrayar que el gremio jurídico también ha participado activamente en la conformación de instituciones educativas y culturales fundadas en la segunda mitad del siglo XX como el Colegio Nacional, la Comisión Nacional de Libros de Texto Gratuito, el Instituto de Investigaciones Dr. José María Luis Mora y el Instituto Matías Romero.

Mención especial merece la labor de los abogados en el sustento de la literatura mexicana en sus diferentes géneros. Por esta causa la calidad del trabajo creativo de escritores con formación jurídica ha sido reconocida con su pertenencia a la Academia Mexicana de la Lengua. De igual forma la cinematografía nacional se ha enriquecido con las historias escritas 
Este libro forma parte del acervo de la Biblioteca Jurídica Virtual del Instituto de Investigaciones Jurídicas de la UNAM

por Martín Luis Guzmán, Carlos Montemayor y Víctor Hugo Rascón Banda.

Por otra parte, es sobresaliente la actividad periodística ejercida por algunos de los biografiados en este capítulo. Ellos procuraron colaborar en la educación de sus contemporáneos, publicando artículos de opinión sobre política o cultura, algunos ejercieron el periodismo como críticos de arte; en muchas ocasiones hicieron uso de los periódicos y las revistas para concientizar a sus contemporáneos de problemas sociales y económicos, y de las disfunciones de la política. Hombres de cultura enciclopédica fueron estos abogados creadores de cultura, a quienes les interesó dejar testimonio de las transformaciones de México después de dos guerras mundiales e intensos procesos de modernización generados por la tecnología-, y procurar la preservación de nuestras raíces culturales.

\section{JOSÉ VASCONGELOS}

Su nombre completo fue José Vasconcelos Calderón. Nació el 27 de febrero de 1882 en la Ciudad de Oaxaca, Oaxaca, falleció en la Ciudad de México el 30 de junio de 1959. En virtud de que su padre era funcionario federal del gobierno de Porfirio Díaz, José Vasconcelos cambió frecuentemente de residencia en su niñez (vivió en Sonora, Coahuila, Campeche y Estado 
Este libro forma parte del acervo de la Biblioteca Jurídica Virtual del Instituto de Investigaciones Jurídicas de la UNAM

de México). ${ }^{78}$ Estudió en la Escuela Nacional Preparatoria y posteriormente realizó la carrera de abogado en la Escuela Nacional de Jurisprudencia, titulándose en 1905 con la tesis "Teoría dinámica del derecho" (publicada en 1907). Ejerció la abogacía en diferentes lugares, cuando fue pasante de derecho trabajó en la notaría del abogado Aguilar y Marocho, también colaboró en el juzgado que estaba a cargo de Jesús Uriarte y con él posteriormente litigó en un bufete jurídico. ${ }^{79}$ Tiempo después trabajó en el norte de México, específicamente en el despacho norteamericano de abogados Warner, Jhonson and Galston, y en las postrimerías del Porfiriato se unió a los maderistas participando en la jefatura del Centro Antirreeleccionista de México y como encargado del periódico de ese organismo, denominado El antirreeleccionista, función que realizó con Félix F. Palavicini (quien sería integrante del Congreso Constituyente de 1917).

En la etapa de la Revolución Constitucionalista José Vasconcelos formó parte del gabinete de Eulalio Gutiérrez, nombrado presidente de México por la Convención de Aguascalientes, ${ }^{80}$ el cargo ejercido por

78 Lozada León, Guadalupe, "Introducción", Fosé Vasconcelos hombre, educador y candidato, México, UNAM, Coordinación de $\mathrm{Hu}-$ manidades, 1998, Biblioteca del Estudiante Universitario, núm. 123, pp. VII-IX.

79 Vasconcelos, José, Ulises criollo, 3a. ed., México, Porrúa, 2001, pp. 143-194.

80 Convención Nacional Revolucionaria. 
Este libro forma parte del acervo de la Biblioteca Jurídica Virtual del Instituto de Investigaciones Jurídicas de la UNAM

el oaxaqueño fue el de titular de la Secretaría de Instrucción Pública y Bellas Artes (de diciembre de 1914 al 15 de enero de 1915).81 Al triunfo del grupo sonorense Vasconcelos se desempeñó como rector de la Universidad Nacional de México, ocupando el cargo del 9 de junio de 1920 al 12 de octubre de 1921 (fue nombrado por el presidente de la República Adolfo de la Huerta), en su gestión como rector dotó a la máxima casa de estudios del país del lema y el escudo que hasta la fecha distinguen a la institución, el escudo solamente ha tenido una variante respecto al propuesto por Vasconcelos, es la incorporación del término "autónoma". ${ }^{82}$

La vinculación de Vasconcelos con las actividades culturales provenía de su participación en el Ateneo de la Juventud (funcionó de 1909 a 1914), al cual también pertenecieron Antonio Caso, Julio Torri y Pedro Henríquez Ureña, quienes posteriormente colaboraron con el abogado oaxaqueño en la Secretaría de Educación Pública. ${ }^{83}$ El propio Vasconcelos promovió la creación

81 Véase wrerc.sep.gob.mx/es/sep1/Semblanza_Fosé_Vasconcelos.

82 Respecto a las ideas de José Vasconcelos que lo inspiraron para dotar a la UNAM de esta simbología véase Valadés, Diego, Laicidad y cultura, México, UNAM, Instituto de Investigaciones Jurídicas-Cátedra Extraordinaria Benito Juárez, 2013, pp. 41-47.

83 Garciadiego, Javier, "La gran revolución educativa. El triunfo de Vasconcelos", Relatos e historias de México, México, núm. 75, noviembre de 2014, p. 41. 
Este libro forma parte del acervo de la Biblioteca Jurídica Virtual del Instituto de Investigaciones Jurídicas de la UNAM

de esta Secretaría, misma que comenzó a operar en 1921, ${ }^{84}$ en el régimen del presidente Álvaro Obregón. El intelectual oaxaqueño estuvo al frente de ella dos años ocho meses (12 de octubre de 1921 a 2 de julio de 1924), en los cuales implementaría una política educativa de aprecio de los valores culturales mexicanos, ocupando un lugar preponderante la enseñanza, práctica y difusión del arte popular, esto último como una cristalización de los ideales de la Revolución mexicana. La política cultural ideada y puesta en acción por Vasconcelos sería un aval para el gobierno de Obregón ante el mundo, especialmente en Latinoamérica, y a la postre fue la sólida base en la que se construyó el discurso del nacionalismo revolucionario que sustentaría al partido oficial (PNR, PRM y PRI).

En su gestión, Vasconcelos hizo remodelar el ex convento de la Encarnación, ubicado en la calle de Argentina, para albergar a la nueva Secretaría, el edificio fue inaugurado el 9 de julio de 1922. Vasconcelos dividió la Secretaría de Educación Pública en tres grandes departamentos: escolar, bibliotecas y Bellas Artes. ${ }^{85}$ El abogado oaxaqueño promovió una amplia campaña de alfabetización en todo el país, misma que consistió, entre otras acciones en la impresión de obras de

84 El 3 de octubre de 1921 se publicó en el Diario Oficial de la Federación el Decreto que crea la Secretaría de Educación Pública.

85 Mares, Roberto, Fosé Vasconcelos, México, Grupo Editorial Tomo, 2004, pp. 83 y 84 . 
Este libro forma parte del acervo de la Biblioteca Jurídica Virtual del Instituto de Investigaciones Jurídicas de la UNAM

autores clásicos grecolatinos que se regalaban en diferentes partes de México, asimismo promovió brigadas de intelectuales que enseñaban a leer principalmente a obreros; Vasconcelos nombró a Vicente Lombardo Toledano como director del Departamento de Bibliotecas de la Secretaría de Educación, desde donde editarían la colección El libro y el pueblo. ${ }^{86}$ La Secretaría de Educación Pública editó varias revistas educativas como El maestro. Revista de cultura nacional, en ésta participó activamente el pintor Diego Rivera, quien a su regreso de Europa fue nombrado por Vasconcelos como consultor y dibujante del Departamento de Bibliotecas. ${ }^{87}$ Por otra parte, también es importante destacar que Vasconcelos invitó a participar en las tareas culturales de México a la poetisa chilena Gabriela Mistral, cuyo libro Lectura para mujeres circuló en nuestro país con un tiraje de veinte mil ejemplares. ${ }^{88}$

José Vasconcelos fue impulsor del muralismo mexicano, pues durante su administración los pintores David Alfaro Siqueiros, José Clemente Orozco y Diego Rivera iniciaron la creación de murales en la Escuela

86 Sobre estas acciones de política cultural de Vasconcelos véase Krauze, Enrique, Caudillos culturales en la Revolución mexicana, México, Siglo XXI Editores, 2000, pp. 107-109.

87 Tibol, Raquel, "Diego Rivera dibujante", Diego Rivera gran ilustrador, México, Museo Nacional de Arte, 2007, pp. 11, 12 y 55.

88 Yankelevich, Pablo, "Los ecos de la Revolución mexicana en Latinoamérica", Relatos e historias en México, México, núm. 16, diciembre de 2009, p. 18. 
Este libro forma parte del acervo de la Biblioteca Jurídica Virtual del Instituto de Investigaciones Jurídicas de la UNAM

Nacional Preparatoria (edificio de San Ildefonso) ${ }^{89}$ y en 1923 Diego Rivera dio comienzo a los murales del edificio de la Secretaría de Educación Pública. José Vasconcelos también fue el impulsor de la estación radiofónica CZE (inaugurada a finales de 1924) que hoy funciona con el nombre de Radio Educación y fue la primera radioemisora cultural de América Latina. ${ }^{90}$ Asimismo, la infraestructura para la educación física fue fomentada en esta administración, siendo su mejor producto el Estadio Nacional (construido en la Ciudad de México); también se fundó la Escuela Elemental de Educación Física para contar con una institución laica dedicada a esta clase de enseñanza, ya que en nuestro país solamente la impartían organismos dependientes de las iglesias protestantes. ${ }^{91}$

89 En la gestión de Vasconcelos dentro de este recinto, Alfaro Siqueiros pintó el mural denominado El llamado de la libertad (1922); Orozco hizo lo propio denominando a su obra Maternidad (19231924), y Diego Rivera engalanó el anfiteatro Simón Bolívar con el mural La creación (1922). Por su parte, el artista francés Jean Charlot realizó el mural Masacre en el templo mayor o la Conquista de Tenochtitlan (1923-1924). Cfr. wwew.sanildefonso.org.mx/acervo.php y Guadarrama Peña, Guillermina, "Bocetos y secretos en los murales de San Ildefonso", publicado en http://discursovisual.cenart.gob.mx.

90 Bohmann, Karin, Medios de comunicación y sistemas informativos en México, México, Alianza Editorial-Consejo Nacional para la Cultura y las Artes, 1990, pp. 92 y 93.

91 Rivera Gómez, Nidia, "El físico sí importa. En 1923 se creó la Escuela Elemental de Educación Física como parte del proyecto 
Este libro forma parte del acervo de la Biblioteca Jurídica Virtual del Instituto de Investigaciones Jurídicas de la UNAM

El intelectual oaxaqueño renunció al cargo de secretario de Educación Pública en protesta por las anomalías que se observaban en las investigaciones sobre el asesinato del senador por Campeche Francisco Field Jurado. En esta etapa Vasconcelos se postuló como candidato a la gubernatura de Oaxaca pero su esfuerzo fracasó. En esta época el abogado Vasconcelos fundó la publicación llamada La Antorcha, en la que también participaron Vito Alessio Robles, Carlos Pellicer y Julio Torri, fue una revista opositora al régimen político. Tras su derrota electoral José Vasconcelos salió de México y viajó por Europa, a su regreso al continente americano trabajó como profesor en la Universidad de Chicago. ${ }^{92}$ Retornó a México en 1928 para lanzarse como candidato a la Presidencia de la República en las elecciones de 1929 como opositor a Pascual Ortiz Rubio (candidato oficial, postulado por el Partido Nacional Revolucionario).

Al término de los comicios Vasconcelos se quejó de un fraude oficial y manifestó su descontento mediante el Plan de Guaymas, conocido como Plan Vasconcelista, del 10 de diciembre de 1929, en él menciona que la prensa estadounidense dio la noticia de que el gana-

vasconcelista", Relatos e historias en México, México, núm. 77, enero de 2015, pp. 78-81.

92 Lozada León, Guadalupe, op. cit., nota 78, pp. LXII-LXVII y Rosas, Alejandro, fosé Vasconcelos, México, Consejo Nacional para la Cultura y las Artes, 2008, pp. 25-29. 
Este libro forma parte del acervo de la Biblioteca Jurídica Virtual del Instituto de Investigaciones Jurídicas de la UNAM

dor de la contienda electoral era Ortiz Rubio. En su parte medular el Plan de Vasconcelos establecía:

Considerando, entonces, que es necesario exigir al pueblo que lleve adelante el esfuerzo que va implícito en el voto, me dirijo a todos mis conciudadanos, pidiéndoles adhesión decidida para las resoluciones siguientes:

I. Se declara que no hay en la República más autoridad legítima, por el momento, que el C. Licenciado José Vasconcelos, electo por el pueblo en los comicios del 19 de noviembre de 1929 para la Presidencia de la República. En consecuencia, serán severamente castigadas todas las autoridades, inclusive los miembros del Ejército, que sigan prestando apoyo al Gobierno que ha traicionado el objeto para el cual fue creado...

II. Se desconoce a todos los poderes de facto, así los de la Federación como los de los estados y municipios, que desde hace treinta años han venido ensangrentando al país, robando el Tesoro público y creando la confusión y la ruina de la Patria, y que han pretendido burlar el voto público en la elección presidencial última...

El Presidente Electo se dirige ahora al extranjero; pero volverá al país a hacerse cargo directo del mando tan pronto como haya un grupo de hombres libres armados que estén en condiciones de hacerlo respetar. 
Este libro forma parte del acervo de la Biblioteca Jurídica Virtual del Instituto de Investigaciones Jurídicas de la UNAM

Hágase circular y cúmplase. Dado en Guaymas, Estado de Sonora, el 10 de diciembre de 1929.

J. Vasconcelos ${ }^{93}$

El historiador Enrique Krause hace un recuento del conjunto de prácticas de boicots que se hicieron a la campaña vasconcelista, hubo disolución de mítines mediante la fuerza armada, a través del periódico oficialista, el Nacional Revolucionario, se denostó la política educativa implementada por el abogado oaxaqueño difundiendo que "no se gobierna un país con enseñanza literaria... el PNR no distribuye La Iliada... sino treinta y cinco millones de hectáreas". Los ataques a los simpatizantes de Vasconcelos fueron aumentando de intensidad y durante la campaña, uno de ellos, el joven Germán del Campo murió acribillado en la calle. En meses posteriores a las elecciones, en marzo de 1930, se realizó una sangrienta matanza, en Topilejo, de partidarios de Vasconcelos. ${ }^{94}$

El fraude electoral que sufrió el destacado filósofo oaxaqueño no generó un levantamiento generalizado de la sociedad, por ello Vasconcelos salió del país y

93 Texto reproducido en Iglesias González, Román (comp.), Planes politicos, proclamas, manifiestos y otros documentos de la Independencia al México moderno, 1812-1940, México, UNAM, Instituto de Investigaciones Jurídicas, 1998, pp. 961-963.

94 Krause, Enrique, Biografia del poder. Caudillos de la Revolución mexicana (1910-1940), México, Tusquets Editores, 2002, p. 365. 
Este libro forma parte del acervo de la Biblioteca Jurídica Virtual del Instituto de Investigaciones Jurídicas de la UNAM

viajó a distintas naciones, entre ellas estuvo en Estados Unidos de Norteamérica, ${ }^{95}$ regresó a México en 1940 dedicándose a escribir sobre temas diversos.

El abogado Vasconcelos fue un prolífico escritor, publicó libros de temas históricos como Hernán Cortes, creador de la nacionalidad ${ }^{96}$ y Breve historia de México. También nos legó sus trabajos autobiográficos denominados Ulises criollo, La raza cósmica, La tormenta, El desastre y El proconsulado. Su pensamiento fue ecléctico pues se dedicó al estudio de la filosofía pero siempre estuvo fuertemente influenciado por las ideas del catolicismo (que le fueron inculcadas por su progenitora), a tal grado que en su libro La raza cósmica Vasconcelos afirmó:

En efecto, la decadencia de los pueblos asiáticos es atribuible a su aislamiento, pero también, y sin duda, en primer término, al hecho de que no han sido cristianizados. Una religión como la cristiana hizo avanzar a los indios americanos, en pocas centurias, desde el canibalismo hasta la relativa civilización. ${ }^{97}$

95 Véase Rosas, Alejandro, "Unidos por el exilio Calles y Vasconcelos en Estados Unidos", Relatos e historias de México, México, núm. 51, noviembre de 2012, pp. 79-84.

96 Con motivo del bicentenario del inicio de la Independencia de México se publicó una nueva edición de esta obra consultable como Vasconcelos, José, Hernán Cortés, creador de la nacionalidad, México, Trillas, 2010.

97 Vasconcelos, José, La raza cósmica, México, Porrúa, 2007, p. XVII. 
Este libro forma parte del acervo de la Biblioteca Jurídica Virtual del Instituto de Investigaciones Jurídicas de la UNAM

José Vasconcelos fue reconocido por el gobierno mexicano al ser nombrado miembro fundador del Colegio Nacional creado por decreto del presidente Manuel Ávila Camacho en 1943,98 según establece el artículo 2o. de dicho decreto:

El propósito general del Colegio será impartir por hombres eminentes, enseñanzas que representen la sabiduría de la época, esforzándose porque el conocimiento especializado de cada una de las cátedras concurra, fundamentalmente a fortalecer la conciencia de la nación, perpetuada en generaciones sucesivas de personas relevantes por su ciencia y virtudes.

La labor intelectual de este destacado personaje ha sido motivo de otros homenajes, por ejemplo, el plantel 5 de la Escuela Nacional Preparatoria lleva el nombre de tan distinguido mexicano. En el 2010 con motivo del centenario de la Revolución mexicana se acuñó y puso en circulación una moneda con el retrato de don José. En tanto, durante el 2011 la Secretaría de Educación Pública emitió el libro José Vasconcelos. La creación de

98 Los otros integrantes del Colegio Nacional fueron: Mariano Azuela, Alfonso Caso, Antonio Caso, Carlos Chávez, Ezequiel A. Chávez, Ignacio Chávez, Enrique González Martínez, Isaac Ochoterena, Ezequiel Ordóñez, José Clemente Orozco, Alfonso Reyes, Diego Rivera, Manuel Sandoval Vallarta y Manuel Uribe Troncoso. Información obtenida de wrere.colegionacional.org.mx/Fundaci.htm, consultada el 5 de septiembre de 2006. 
Este libro forma parte del acervo de la Biblioteca Jurídica Virtual del Instituto de Investigaciones Jurídicas de la UNAM

la Secretaría de Educación Pública, en el cual se incorporaron fragmentos de obras del abogado oaxaqueño, ello en el marco de los festejos del aniversario número 90 de dicha Secretaría. ${ }^{99}$

\section{MARTÍN LUIS GUZMÁN}

Su nombre completo fue Martín Luis Guzmán Franco. Nació el 6 de octubre de 1887 en Chihuahua, Chihuahua, pero en un texto autobiográfico el propio Guzmán afirmó que nació en la Ciudad de México, en la zona de Tacubaya. ${ }^{100}$ Según Francisco Monterde, Guzmán nació en Chihuahua; sin embargo, a los pocos meses de ello la familia Guzmán Franco se trasladó a la capital de la República, porque el padre de Guzmán fue comisionado para trabajar en el Colegio Militar. ${ }^{101}$ Martín Luis Guzmán falleció en la Ciudad de México

99 Publicado a través del Instituto Nacional de Estudios Históricos de las Revoluciones de México, México, 2011. Contiene una presentación del entonces secretario de Educación Pública, Alonso Lujambio, la introducción, selección de textos y notas corrió a cargo de Carlos Betancourt Cid.

100 Guzmán, Martín Luis, "Apunte sobre una personalidad", en Guzmán, Martín Luis, Obras completas, México, Fondo de Cultura Económica, 2013, t. II, p. 461.

101 Monterde, Francisco, "Prólogo", Dos novelas de la Revolución. Los de abajo. La sombra del caudillo, México, Secretaría de Educación Pública-UNAM, 1982, p. 115. 
Este libro forma parte del acervo de la Biblioteca Jurídica Virtual del Instituto de Investigaciones Jurídicas de la UNAM

el 22 de diciembre de 1976. Este escritor defendió permanentemente los principios liberales y el respeto a la laicidad.

En 1908 Guzmán escribió en el periódico oficialista El Imparcial, concluyó su formación en la Escuela Nacional Preparatoria y a partir de 1909 realizó sus estudios de derecho en la Ciudad de México, en la Escuela Nacional de Jurisprudencia (hoy Facultad de Derecho de la UNAM) en donde tuvo como compañero a Alfonso Reyes. En esta etapa apoyó la reelección de Porfirio Díaz y en agosto de 1909 recibió el nombramiento de cónsul de México en Phoenix, Arizona. En 1910 Guzmán se vio forzado a regresar a México, porque su padre, coronel del ejército, fue gravemente herido al enfrentar a los revolucionarios, pero antes de morir confesó que éstos tenían razón de oponerse a la dictadura de Díaz. ${ }^{102}$ En 1911 el futuro escritor trabajó como bibliotecario en la Escuela Nacional de Altos Estudios y participó en los trabajos del Ateneo de la Juventud, se unió al maderismo a través del Partido Liberal Constitucionalista. Durante la Revolución Constitucionalista, en 1914 formó parte del estado mayor de los generales Ramón F. Iturbe y Álvaro Obregón, después se incorporó al ejército villista,

102 Curiel Defossé, Fernando, "Introducción”, en Guzmán, Martín Luis, Caudillos y otros extremos. Antología, México, UNAM, 2010, Biblioteca del Estudiante Universitario, núm. 115, p. XVII. 
Este libro forma parte del acervo de la Biblioteca Jurídica Virtual del Instituto de Investigaciones Jurídicas de la UNAM

pero por decisión propia dejó las filas revolucionarias y se trasladó con su familia a Estados Unidos de Norteamérica para luego irse a radicar a Europa.

$\mathrm{Su}$ vida estuvo dedicada a la escritura ejerciéndola en el campo literario y en la profesión periodística. Su primer libro, titulado La querella de México, se publicó en 1916, en Madrid, España, en este texto hace una crítica a la idea prevaleciente en México de que los criollos poseían más valores culturales que los indígenas; también enfatiza la importancia de la educación para el desarrollo del país. Este ensayo fue muy conocido entre la intelectualidad de la época, de ello da cuenta la carta que el pintor Diego Rivera envió a Guzmán opinando favorablemente sobre La querella de México. ${ }^{103}$

Regresó a México en 1919 dedicándose a escribir en el periódico El Heraldo, cuyo propietario era el revolucionario sinaloense Salvador Alvarado. En esta etapa Martín Luis trabajó en la Secretaría de Relaciones Exteriores a las órdenes de Alberto J. Pani (en el gobierno de Álvaro Obregón). ${ }^{104}$ En 1920 Guzmán publicó el libro A orillas del Hudson constituido por los artículos

103 Rivera, Diego, "Carta a Martín Luis Guzmán”, París, 2 de febrero de 1916, en Guzmán, Martín Luis, La querella de México, México, Conaculta-Planeta, 2002, pp. 55-57.

104 Betancourt Cid, Carlos, "Martín Luis Guzmán", en Torres Parés, Javier y Villegas Moreno, Gloria (coords.), Diccionario de la Revolución mexicana, México, UNAM, 2010, p. 561. 
Este libro forma parte del acervo de la Biblioteca Jurídica Virtual del Instituto de Investigaciones Jurídicas de la UNAM

periodísticos que él había difundido en Nueva York, entre 1916 y 1918 (en plena Primera Guerra Mundial), a través de los medios mexicanos Revista Universal y El Gráfico, entre ellos encontramos uno de elogio al presidente norteamericano Woodrow Wilson, titulado "Enaltezcamos a Wilson", también hace una reseña del nuevo libro The whole truth about Mexico que por esa época publicara Francisco Bulnes; en el renglón del arte Guzmán se ocupa de "Alfonso Reyes y las letras mexicanas" (con motivo de la edición de su libro $E l$ suicida, de 1917, editado en Madrid) y de "Diego Rivera y la filosofía del cubismo", del artista guanajuatense escribió Martín Luis Guzmán lo siguiente:

Rivera es un maestro y un sabio del arte. La misma sensación plácida, de espectáculo fácil y combinado, invade el espíritu cuando los ojos lo siguen en los seguros movimientos de su pincel sobre el lienzo o la paleta, que cuando se escucha el correr familiar de su charla pictórica. Yo he posado seis días ante su mirada reveladora - seis días de un calor estival, envuelto yo en un sarape zacatecano-, y no recuerdo horas más entretenidas ni más llenas de paz. Aun las nuevas teorías del cubismo adquieren en labios de Diego un aire de reposo que ahuyenta la duda y la inquietud...

En el régimen de Álvaro Obregón el escritor Guzmán fundó un periódico vespertino llamado El mundo (1922), empresa informativa que se expandió por- 
Este libro forma parte del acervo de la Biblioteca Jurídica Virtual del Instituto de Investigaciones Jurídicas de la UNAM

que con ese mismo nombre se creó una radiodifusora, también propiedad de Martín Luis en 1923, ambos medios de comunicación fueron bastiones del escritor para coadyuvar en la tarea de cultivar a la población inculcándole las ideas nacionalistas del régimen posrevolucionario. Lamentablemente ambos proyectos informativos se vieron truncados por la enemistad que Guzmán se acarreó con el gobierno presidencial por ser partidario de Adolfo de la Huerta. ${ }^{105}$

Al ser derrotada la rebelión de Adolfo de la Huerta, el escritor salió de México para radicar en España durante el periodo de 1924-1936, país en el que ejerció el periodismo y asesoró al presidente Manuel Azaña. Este segundo periodo en la vida de Guzmán fuera de su país fue altamente benéfico para el enriquecimiento de la literatura latinoamericana porque el escritor chihuahuense creó obras sobresalientes de contenido político, pues Guzmán fue autor de dos novelas fundamentales de las letras mexicanas, La sombra del caudillo (publicado en 1929) misma que fue llevada al cine posteriormente, y El águila y la serpiente (publicado en 1928), constituyéndose en un autor clásico de la novela de la Revolución mexicana. Martín Luis aprovechó su estancia en España para hacer indagaciones de cor-

105 Sobre esta fase de la vida del escritor véase Mahieux, Viviane, "Martín Luis Guzmán fracasa en la radio", Nexos, México, septiembre de 2012. 
Este libro forma parte del acervo de la Biblioteca Jurídica Virtual del Instituto de Investigaciones Jurídicas de la UNAM

te histórico cuyo fruto fue la novela Javier Mina, héroe de España y de México.

Al finalizar el régimen del presidente Lázaro Cárdenas, en 1940, Guzmán publicó la novela Memorias de Pancho Villa, creación que se convirtió en una herramienta reivindicadora del papel del revolucionario duranguense en la historia del siglo XX mexicano. En 1942 fundó la revista Tiempo, en la cual trabajaría hasta su fallecimiento, en 1976. Martín Luis Guzmán perteneció a la Academia Mexicana de la Lengua, donde ocupó la silla XIII, realizó la lectura de su discurso de ingreso el 19 de febrero de 1954, el discurso se tituló "Apunte sobre una personalidad". De junio de 1951 a 1965 fue representante adjunto de nuestro país ante la Organización de las Naciones Unidas (ONU). ${ }^{106}$

Los mayores logros en lo que se refiere al reconocimiento de la trayectoria de Martín Luis Guzmán se efectuaron durante la administración del presidente Adolfo López Mateos (diciembre de 1958-noviembre de 1964), pues desde la campaña electoral de éste el legendario novelista formó parte de la comitiva de López Mateos y lo asesoró en temas educativos. En 1958 Guzmán se hizo merecedor del Premio Nacional de Ciencias y Artes, en la especialidad de Literatura y Lingüística, por la novela Muertes históricas.

106 Información consignada en http://acervo.sre.gob.mx/index, consultada el 3 de noviembre de 2015. 
Este libro forma parte del acervo de la Biblioteca Jurídica Virtual del Instituto de Investigaciones Jurídicas de la UNAM

En el sector cultural fue de primordial importancia su trabajo al frente de la Comisión Nacional de Libros de Texto Gratuito (Conaliteg), cargo que ejerció de 1959 (fue director fundador) a 1976. Esta Comisión la creó el presidente Adolfo López Mateos a instancias de Jaime Torres Bodet, Secretario de Educación Pública, con la finalidad de emprender una amplísima campaña de alfabetización y crear una herramienta didáctica que beneficiara a todos los niños del país, haciendo efectivas las garantías contenidas en el artículo 3o. constitucional. Según datos oficiales, bajo la dirección de Guzmán en 1960 se produjeron 19 títulos para alumnos de primaria y dos para maestros, cuyas portadas fueron ilustradas por artistas de reconocido prestigio como David Alfaro Siqueiros, Raúl Anguiano, Alfredo Montenegro y Alfredo Zalce. A partir de 1962 se utilizó en la portada de los libros la obra denominada "La patria", de Jorge González Camarena. En 1966 se produjeron libros en el sistema Braille. ${ }^{107}$ Esta Comisión es un organismo público descentralizado del gobierno federal. ${ }^{108}$

107 "Historia de 1944 a 1982", México, Comisión Nacional de Libros de Texto Gratuito, en wrere.conaliteg.gob.mx/index.php, consultada en octubre de 2015.

108 Véase Estatuto orgánico de la Comisión Nacional de Libros de Texto Gratuito, Diario Oficial de la Federación, México, 5 de marzo de 2008. 
Este libro forma parte del acervo de la Biblioteca Jurídica Virtual del Instituto de Investigaciones Jurídicas de la UNAM

Entre las escasas frustraciones que Guzmán Franco padeció en la década de los sesenta se halla un problema de censura hacia una de sus obras. Como mencioné, el argumento de La sombra del caudillo fue llevada al cine, dirigida por Julio Bracho en 1960, el tema resultó polémico porque se refiere a la muerte del general Francisco Serrano y aunque tanto en la novela como en la película se utilizan nombres ficticios para los personajes, por ser hechos trascendentes y muy publicitados, algunos integrantes del Ejército mexicano influyeron para que la cinta permaneciera casi sin exhibiciones, ${ }^{109}$ aunque sí llegó a ser estrenada y, según algunos autores, tuvo difusión por el uso de copias en cassettes. ${ }^{110}$

En la administración del presidente Gustavo Díaz Ordaz se realizaron diferentes celebraciones para Guzmán con motivo de su cumpleaños número ochenta, el mismo Díaz Ordaz le hizo llegar una carta de felicitación calurosa, después, en junio de 1968, Martín Luis Guzmán hizo uso de la palabra en representación de

109 Un trabajo muy completo e ilustrativo sobre el periplo de esta película para su exhibición es Vega Alfaro, Eduardo de la, $L a$ Revolución traicionada. Dos ensayos sobre literatura, cine y censura, México, UNAM, Centro Universitario de Estudios Cinematográficos, 2012, pp. 81-158.

110 García Riera, Emilio, Breve historia del cine mexicano, primer siglo (1897-1997), México, Consejo Nacional para la Cultura y las Artes-Ediciones Mapa, 1998, p. 219. 
Este libro forma parte del acervo de la Biblioteca Jurídica Virtual del Instituto de Investigaciones Jurídicas de la UNAM

los editores de prensa para rogarle al jefe del Ejecutivo que los acompañara a la comida que se efectuaba anualmente con motivo del día de la libertad de prensa. Con estos antecedentes resulta relativamente entendible la posición que el semanario Tiempo de Martín Luis asumiera ante la matanza de los estudiantes el 2 de octubre de 1968, el periodista Rafael Rodríguez Castañeda recuperó lo publicado en esa revista tras los sangrientos hechos en Tlatelolco:

En el caso de la reciente agitación estudiantil se enfrentaron con los intereses de la sociedad y del Estado las pretensiones ilegítimas de una turba, denominación que merece, sea cual fuere la ocupación habitual de quienes la componían. ${ }^{11}$

Fue profundamente lamentable esta expresión de Guzmán ante un acto de brutalidad del régimen político mexicano, ello generó repudio al sobresaliente escritor, lo cual no fue impedimento para que posteriormente, en el lapso 1970 a 1976, se desempeñara como senador de la República postulado por el Partido Revolucionario Institucional. ${ }^{112}$

111 Rodríguez Castañeda, Rafael, Prensa vendida. Los periodistas y los presidentes: 40 años de relaciones, México, Grijalbo, 1993, p. 120.

112 Algunos discursos pronunciados por Martín Luis Guzmán en su carácter de senador aparecen publicados en Luna, Andrés de (comp.), Martín Luis Guzmán, México, Cámara de Senadores de la República Mexicana, Legislatura LIII, 1987, pp. 103-128. 
Este libro forma parte del acervo de la Biblioteca Jurídica Virtual del Instituto de Investigaciones Jurídicas de la UNAM

El "22 de diciembre de 1976, en su oficina de la colonia Juárez, Martín Luis Guzmán murió rodeado de sus apuntes, diccionarios, pruebas de su revista Tiempo". ${ }^{13} \mathrm{Su}$ fondo documental es parte del archivo histórico de la Universidad Nacional Autónoma de México.

A 39 años de su fallecimiento las aportaciones de Guzmán a la cultura de México siguen siendo objeto de reconocimiento, de tal suerte que en el 2015 el Museo de Arte Moderno de México inauguró una exposición temporal pictórica y documental dedicada a Martín Luis Guzmán denominada La otra fiesta de las balas. Martín Luis Guzmán, en ella se exhiben 58 obras como pinturas y dibujos de artistas vinculados con el escritor, entre ellas destaca el retrato que le hizo Diego Rivera con estilo cubista, también hay creaciones de Ángel Zárraga, Roberto Montenegro, Saturnino Herrán, Gerardo Murillo y Frida Kahlo. También se ponen ante la vista del público más de 150 documentos del archivo de Guzmán, de la Comisión Nacional de Libros de Texto Gratuitos y de la Escuela Nacional de Danza Nellie y Gloria Campobello. ${ }^{114}$ Fue un aspecto enriquecedor de esta muestra que se haya reser-

113 Alcubirre Moya, Beatriz, y Ramírez Garrido, Jaime, "Martín Luis Guzmán: a la sombra de la Revolución", Nexos, México, diciembre de 2011.

114 "Novedades del pasado. La otra fiesta de las balas", Relatos e historias en México, México, núm. 86, octubre de 2015, p. 14. 
Este libro forma parte del acervo de la Biblioteca Jurídica Virtual del Instituto de Investigaciones Jurídicas de la UNAM

vado un espacio para proyectar la película La sombra del caudillo, la cual se exhibe de manera continua durante el horario de funcionamiento del Museo.

\section{ARTEMIO DE VALLE-ARIZPE}

Nació el 25 de enero de 1884 en Saltillo, Coahuila, murió el 15 de noviembre de 1961 en la Ciudad de México. Es reconocido como uno de los principales exponentes de literatura sobre temas de la época colonial de la Nueva España. En un texto autobiográfico (escrito en 1959) el escritor narra que estudió la preparatoria en el Ateneo Fuente de Coahuila, donde tuvo contacto con la literatura española clásica y menciona que en la biblioteca de su familia había textos jurídicos, especialmente de derecho romano. Después estudió en San Luis Potosí, ahí hizo contacto con clérigos como monseñor Montes de Oca, y trabó amistad con el abogado y poeta Manuel José Othón; en esta temporada De Valle-Arizpe hizo lecturas de temática religiosa. Tiempo después se trasladó a la capital de México para estudiar la carrera de derecho, en esta etapa logró relacionarse con personas importantes de los ámbitos cultural y político como Luis González Obregón, Genaro García y Jesús Galindo y Villa, de igual forma tuvo la oportunidad de consultar los archivos del Ayuntamiento de la Ciudad de México 
Este libro forma parte del acervo de la Biblioteca Jurídica Virtual del Instituto de Investigaciones Jurídicas de la UNAM

y el Archivo General de la Nación. En 1919 publicó su primera novela denominada Ejemplo, misma que se editó en Madrid, España ${ }^{115}$ y fue ilustrada por el pintor mexicano Roberto Montenegro.

En 1910 obtuvo el título de abogado en Coahuila ${ }^{116}$ y se integró como diputado federal al Congreso de la Unión, en representación de Comitán, Chiapas, lugar con el cual no tenía ningún vínculo el joven Artemio; sin embargo, habrá de recordarse que el escritor pertenecía a la clase política gobernante durante el Porfiriato pues su padre, Jesús de Valle (abogado de profesión) se desempeñó al frente del gobierno de Coahuila en varias ocasiones. ${ }^{117}$ Desde 1919 hasta 1928 Artemio realizó actividades diplomáticas en diferentes países, entre ellos España, donde consultó el Archivo de Indias, ello generó en don Artemio un fuerte interés por el conocimiento de la sociedad virreinal de la Nueva España que se reflejaría en varios trabajos literarios e históricos que darían celebridad al abogado coahuilense.

115 Valle-Arizpe, Artemio de, "Historia de una vocación", en Valle-Arizpe, Artemio de, Obras, México, Fondo de Cultura Económica, 2000, t. I, pp. 56-69.

116 Carballo, Emmanuel, Protagonistas de la literatura mexicana, México, Porrúa, 2003, p. 155.

117 Fierro Gossman, Rafael, "La casa de don Artemio de ValleArizpe", Grandes casas de México, en http://grandescasasdemexico.blogspot.mx/2014, consultado en junio de 2014. 
Este libro forma parte del acervo de la Biblioteca Jurídica Virtual del Instituto de Investigaciones Jurídicas de la UNAM

Sus dotes de escritor fueron reconocidos con su ingreso a la Academia Mexicana de la Lengua, primero como miembro correspondiente, en 1924, y posteriormente como miembro de número, para reemplazar a don Victoriano Salado Álvarez en la Silla X. De ValleArizpe presentó su discurso de ingreso en esta Academia el 5 de abril de 1933, cuyo título es "Fray Servando Teresa de Mier Noriega y Guerra". ${ }^{118}$ Habría que mencionar que el académico también redactó y publicó por separado un texto denominado Don Victoriano Salado Álvarez y la conversación en México (1932).

De Valle-Arizpe fue un escritor prolífico, durante su vida publicó 57 libros y participó semanalmente con leyendas en el periódico El Universal. La actividad creativa de este autor fue de temática variada pues realizó trabajos históricos como Virreyes y virreinas de la Nueva España. ${ }^{119}$ Se destacó con novelas como El canillitas y La Güera Rodríguez, esta última ha tenido múltiples ediciones y se ha convertido en un éxito editorial. También sobresalen sus libros de narraciones y leyendas de la época colonial Historias de vivos y muertos. Leyendas, tra-

118 Celorio, Gonzalo, "Artemio de Valle-Arizpe. Biógrafo de Fray Servando", Revista de la Universidad de México, consultada en 2014, en wrerc.revistadelauniversidad.unam.mx/9311/pdf/93celorio.

119 Una edición moderna de esta obra está accesible como Valle-Arizpe, Artemio de, Virreyes y virreinas de la Nueva España, México, Porrúa, 2000. 
Este libro forma parte del acervo de la Biblioteca Jurídica Virtual del Instituto de Investigaciones Jurídicas de la UNAM

diciones y sucedidos del México virreinal, cuya primera edición se efectuó en Madrid, en 1936 y fue reeditada en México en 1947 y 1981, este trabajo está integrado por 31 narraciones sobre la etapa colonial de la Nueva España, aunque incluye una de origen prehispánico, La Llorona.

El abogado Artemio de Valle-Arizpe abordó tangencialmente temas relacionados con las prácticas jurídicas del virreinato dando pormenores de pesquisas hechas por las autoridades para descubrir a los autores de homicidios así como aspectos que permiten conocer la burocracia judicial de la época, me refiero específicamente al relato que don Artemio tituló "Un crimen en el tiempo pasado", por otra parte, en "El testamento" también reflejó historias misteriosas sobre herencias, testamentos y notarios. ${ }^{120}$

Además de las obras ya mencionadas Artemio de Valle-Arizpe publicó: Doña Leonor de Cáceres y Acevedo (1922); Amores y picardías (1932); El palacio nacional de México (1936); Por la vieja calzada de Tlacopan (1937); Andanzas de Hernán Cortés (1940); Personajes de historia y de leyenda (1952); De la Nueva España (1956); Gregorio López, hïo de Felipe II, su vida y su muerte en México (1957); Anecdotario de Manuel José Othón (1958); La casa

120 Ambas historias aparecen publicadas en Valle-Arizpe, Artemio de, Historia, tradiciones y leyendas de calles de México, México, Diana, 1978, pp. 521-548 y 463-478. 
Este libro forma parte del acervo de la Biblioteca Jurídica Virtual del Instituto de Investigaciones Jurídicas de la UNAM

de los Ávila (1960); Leyendas franciscanas (1960); Sombras de un pasado (1961), y Resonancias antiguas (1961).

Con referencia a los homenajes y reconocimientos que se han efectuado a este abogado literato es de destacar que en febrero de 1942 Artemio de ValleArizpe fue designado Cronista de la Ciudad de México, en sustitución de Luis González Obregón. Posteriormente se le puso el nombre del escritor a la calle donde se encontraba su casa en la colonia Del Valle, en Ciudad de México. En 2011 la Escuela de Bachilleres de Coahuila (antes Ateneo Fuente) abrió la sala de arte colonial Artemio de Valle-Arizpe, donde se conserva mobiliario y obras de arte que pertenecieron al escritor. ${ }^{121}$

\section{ERNESTO DE LA TORRE VILLAR}

Nació en Tlatlauqui, Puebla, el 24 de abril de 1917, falleció en la Ciudad de México el 7 de enero de 2009. Estudió las carreras de derecho y letras en la Universidad Nacional Autónoma de México. Realizó estudios de historia en el Colegio de México y en la Escuela Nacional de Antropología. Efectuó estudios de especialidad en la Facultad de Letras de la Universidad Sorbona de París, y en la Escuela de Altos Estudios de la

121 "Abren sala de arte colonial de don Artemio de Valle-Arizpe", México, El diario de Coahuila, 4 de noviembre de 2011. 
Este libro forma parte del acervo de la Biblioteca Jurídica Virtual del Instituto de Investigaciones Jurídicas de la UNAM

Universidad de París. ${ }^{122}$ Se destacó como investigador en las áreas de historia del periodo colonial y de la Independencia de México, también se distinguió por sus estudios sobre libros, bibliófilos, bibliotecas y el guadalupanismo en México.

Se desempeñó como director del Archivo Histórico de la Secretaría de Hacienda y Crédito Público en el periodo (1951-1954). En 1953 ingresó al Instituto de Investigaciones Históricas de la Universidad Nacional Autónoma de México. ${ }^{123}$ Fue director de la Biblioteca Nacional de México de 1965 a 1978, en este periodo (exactamente en 1967) fundó el Instituto de Investigaciones Bibliográficas de la UNAM, del cual fue director de 1967 a 1978. En su gestión como director de la Biblioteca Nacional de México esta institución adquirió importantísimas fuentes documentales como las bibliotecas de Luis G. Miranda (sobre Filipinas), la de Vicente T. Mendoza, la del teniente coronel Silvino González (sobre la Revolución mexicana) y la Colección del doctor Ángel María Garibay, las que ahora se encuentran en el Fondo Reservado de la Biblioteca de la nación. ${ }^{124}$

122 "Ernesto de la Torre Villar", Cultura Mexicana 1942-1992, México, Seminario de Cultura Mexicana, 1992, sección Datos sobre los colaboradores.

123 Según información de wrere.historicas.unam.mx/publicaciones, consultado el 10 de noviembre de 2014.

124 Garritz, Amaya, "Ernesto de la Torre Villar (1917-2009). In Memoriam", en Mayer, Alicia (coord.), Un hombre de libros: home- 
Este libro forma parte del acervo de la Biblioteca Jurídica Virtual del Instituto de Investigaciones Jurídicas de la UNAM

El abogado y bibliófilo también dirigió el Instituto de Investigaciones Dr. José María Luis Mora, de 1981 a 1984. ${ }^{125}$ En 2004 se le puso el nombre de don Ernesto a la Biblioteca de dicha institución como reconocimiento al sólido impulso que le diera durante su breve administración.

De la Torre Villar ejerció la docencia en gran cantidad de instituciones como la Escuela Nacional Preparatoria, la Escuela Normal Superior, la Escuela Nacional de Bibliotecarios y Archivistas, la Facultad de Filosofía y Letras de la UNAM, en la Facultad de Derecho de la Universidad Autónoma de Guadalajara y en la Universidad Iberoamericana. En la Facultad de Filosofía y letras de la UNAM dirigió el Seminario de Historia de México Independiente y el Seminario de Historia Social y Cultural Colonial. Además, participó como profesor visitante de múltiples universidades extranjeras de Europa y Sudamérica.

Fue asiduo colaborador de la Revista de la Universidad de México, es de especial significado el estudio que don Ernesto publicó en esta revista con motivo del centenario de la fundación de la Biblioteca Nacional de México, mismo que apareció como suplemento

naje a Ernesto de la Torre Villar, México, UNAM, Instituto de Investigaciones Históricas, 2012, p. 19.

125 Disponible en wrere.inehrm.gob.mx/es/inehrm/Ernesto_de_la_Torre_Villar, consultado el 6 de noviembre de 2014. 
Este libro forma parte del acervo de la Biblioteca Jurídica Virtual del Instituto de Investigaciones Jurídicas de la UNAM

especial en 1968. ${ }^{126}$ De igual forma participó en revistas académicas como en Anales del Instituto de Investigaciones Estéticas, Boletín del Instituto de Investigaciones Bibliográficas, Estudios de Historia Moderna y Contemporánea y Estudios de Historia Novohispana, las cuatro editadas por la UNAM; así como en el Boletín del Archivo General de la Nación.

Con el fin de dar a conocer la riqueza temática de las investigaciones realizadas por don Ernesto de la Torre Villar y publicadas en dichas revistas mencionaré algunos ejemplos. En Estudios de Historia Moderna y Contemporánea, en 1965 nos ilustró con "La iglesia en México: de la Guerra de Independencia a la Reforma. Notas para su estudio"; 127 en 1980 dio "La política americanista de fray Servando y Tadeo Ortiz; ${ }^{128}$ en 1989 "Minorías religiosas en la novela mexicana del siglo XIX", ${ }^{129}$ y en

126 Torre Villar, Ernesto de la, "México y su Biblioteca Nacional 1867-1967", Revista de la Universidad de México, México, vol. XXII, núm. 6, febrero de 1968, pp. I-VIII.

127 Torre Villar, Ernesto de la, "La iglesia en México: de la Guerra de Independencia a la Reforma. Notas para su estudio", Estudios de Historia Moderna y Contemporánea de México, México, vol. 1, 1965, pp. 9-34.

128 Torre Villar, Ernesto de la, "La política americanista de fray Servando y Tadeo Ortiz", Estudios de Historia Moderna y Contemporánea de México, México, vol. 8, 1980, pp. 67-84.

129 Torre Villar, Ernesto de la, "Minorías religiosas en la novela mexicana del siglo XIX", Estudios de Historia Moderna y Contemporánea, México, vol. 12, 1989, pp. 63-78. 
Este libro forma parte del acervo de la Biblioteca Jurídica Virtual del Instituto de Investigaciones Jurídicas de la UNAM

1991 difundió "Las sociedades de amigos del país y Juan Wenceslao Barquera". 130

Los temas de la historia del derecho en México fueron una de las pasiones intelectuales del abogado De la Torre. Enriquecedores son en este rubro el libro La Constitución de Apatzingán y los creadores del Estado mexicano;"131 los artículos "La Constitución de 1824"132 y "Guía de los periódicos oficiales aparecidos en México, siglo XVIII al XX", 133 así como el "Estudio preliminar" a una obra del abogado decimonónico Juan Wenceslao Barquera. ${ }^{134}$

En su vastísima producción bibliográfica sobresalen: Fray Pedro de Gante: maestro y civilizador de América y

130 Torre Villar, Ernesto de la, "Las sociedades de amigos del país y Juan Wenceslao Barquera", Estudios de Historia Moderna y Contemporánea de México, México, vol. 14, 1991, pp. 11-51.

131 Torre Villar, Ernesto de la, La Constitución de Apatzingán y los creadores del Estado mexicano, 2a. ed., México, UNAM, Instituto de Investigaciones Históricas, 2010.

132 Publicado en Valadés, Diego y Barceló, Daniel (coords.), Examen retrospectivo del sistema constitucional mexicano. A 180 años de la Constitución de 1824, México, UNAM, Instituto de Investigaciones Jurídicas, 2005, pp. 1-7.

133 Torre Villar, Ernesto de la, Breve historia del libro en México, 2a. ed., México, UNAM, 2009, pp. 173-179.

134 Torre Villar, Ernesto de la, "Estudio preliminar", en Barquera, Juan Wenceslao, Lecciones de política y derecho público para la instrucción del pueblo mexicano, México, UNAM, Instituto de Investigaciones Jurídicas, 1991, pp. V-L. 
Este libro forma parte del acervo de la Biblioteca Jurídica Virtual del Instituto de Investigaciones Jurídicas de la UNAM

la doctrina cristiana en la lengua mexicana de 1553, (México, Seminario de Cultura Mexicana, 1973), Labor diplomática de Tadeo Ortiz (México, Secretaría de Relaciones Exteriores, 1974), La independencia mexicana (3 volúmenes, México, SEP-FCE-Consejo Nacional de Fomento Educativo, 1982), Historia de la instrucción pública en Puebla (Puebla, BUAP, 1989), Fray Fuan de Zumárraga y Juan Fosé de Eguiara y Eguren. Dos vidas paralelas (Bilbao, Banco de Vizcaya, 1990), Estudios de historia jurídica (México, UNAM, 1994), Las congregaciones de los pueblos de indios: fase terminal, aprobaciones y rectificaciones (México, UNAM, 1995), Ensayos de sociología religiosa (México, UNAM, 1998) y Breve historia del libro en México (México, UNAM, segunda edición, 2009). Don Ernesto de la Torre realizó importantes investigaciones relacionadas con los aspectos estéticos del mundo editorial, sobresale entre ellas el libro Ex libris y marcas de fuego. ${ }^{135}$ Además fue un acucioso historiador de la biografía del abogado y bibliófilo José Fernando Ramírez. ${ }^{136}$

135 Torre Villar, Ernesto de la, Ex libris y marcas de fuego, 2a. ed., México, UNAM, Dirección General de Publicaciones y Fomento Editorial, 2000.

136 Véase Torre Villar, Ernesto de la, "José Fernando Ramírez", en Clark, Belem y Speckman, Elisa (eds.), La república de las letras. Asomos a la cultura escrita del México decimonónico, México, Coordinación de Humanidades, 2005, vol. III, pp. 116-129. 
Este libro forma parte del acervo de la Biblioteca Jurídica Virtual del Instituto de Investigaciones Jurídicas de la UNAM

El maestro Ernesto de la Torre Villar fue miembro titular del Seminario de Cultura Mexicana, al cual ingresó en noviembre de 1969 presentando el discurso "El libro en la cultura y en el progreso de México". Dentro de sus actividades como integrante de este Seminario realizó un texto de presentación a una obra de su colega Sergio García Ramírez. ${ }^{137}$ Perteneció a la Academia Mexicana de la Lengua con calidad de miembro de número, ocupó la silla XXIX desde el 13 de marzo de $1970^{138}$ y se retiró el 23 de noviembre de 2006. ${ }^{139}$

Se le nombró investigador emérito de la UNAM, en 1994. Perteneció al Sistema Nacional de Investigadores como investigador emérito. En 1986 el gobierno de Venezuela lo distinguió como miembro de la Orden Andrés Bello, en grado de comendador. En 1987 el gobierno de México le otorgó el Premio Nacional de Ciencias y Artes, en el área de ciencias sociales, historia y filosofía. Como reconocimiento a su labor a favor de la cultura de México el Instituto Nacional de Estudios Históricos de las Revoluciones de

137 Torre Villar, Ernesto de la, "Preliminar", en García Ramírez, Sergio, Escritos literarios, México, Seminario de Cultura Mexicana, 2005.

138 Véase rerrreacademia.org.mx/DetalleAcademico, consultada el 11 de noviembre de 2014.

139 Academia Mexicana de la Lengua, Anuario 2008, México, Academia Mexicana de la Lengua, 2007, p. 91. 
Este libro forma parte del acervo de la Biblioteca Jurídica Virtual del Instituto de Investigaciones Jurídicas de la UNAM

México instituyó el premio "Ernesto de la Torre Villar en Investigación Histórica sobre la Independencia de México". En la Biblioteca Nacional de México la Sala Mexicana lleva el nombre del abogado y bibliófilo De la Torre Villar.

\section{JOSÉ Fuentes MARES}

Nació en 1919 en Chihuahua, Chihuahua, misma ciudad en la que falleció en 1986. Realizó sus estudios de licenciatura en derecho y doctorado en filosofía en la Universidad Nacional Autónoma de México, obtuvo el título de licenciatura en 1943, defendiendo la tesis $\mathrm{La}$ sociedad política. En 1944 se graduó como doctor en Filosofía con la tesis Kant filósofo del Estado moderno. ${ }^{140}$

Ejerció la docencia en la Facultad de Filosofía y Letras de la Universidad Nacional Autónoma de México. Decidió regresar a su estado natal y se desempeñó como rector de la Universidad Autónoma de Chihuahua así como en el cargo de director de la Facultad de leyes de esta universidad, al final de la década de los cincuenta. ${ }^{141}$

En España fue profesor invitado de las Universidades de Santander y Sevilla, y en los Estados Unidos

140 Catálogo Tesiunam, consultado el 23 enero de 2014.

141 González y González, Luis, "José Fuentes Mares 19191986", en http://wrere.acadmexhistoria.org.mx, consultada el 23 de noviembre de 2014. 
Este libro forma parte del acervo de la Biblioteca Jurídica Virtual del Instituto de Investigaciones Jurídicas de la UNAM

de Norteamérica fue investigador en los Archivos Nacionales de Washington ${ }^{142}$. José Fuentes Mares fue un prolífico y exitoso autor de libros sobre diferentes temas que le permitieron vivir de sus regalías. Sus obras fueron básicamente sobre historia, filosofia y literatura y gastronomía.

Respecto a los libros sobre historia de México sobresale Poinsett, historia de una gran intriga (1951), mismo que fue publicado tras las investigaciones hechas por Fuentes Mares en Estados Unidos de Norteamérica donde obtuvo una beca de la Fundación Rockefeller. Posteriormente realizó una biografía del chihuahuense Luis Terrazas titulada $\Upsilon$ México se refugió en el desierto. Luis Terrazas: historia y destino (1953). Fueron también de gran éxito e interés los libros Miramón, el hombre (1974); Juárez y los Estados Unidos (1960); Santa Anna, aurora y ocaso de un comediante (1956), y Biografia de una nación: de Cortés a López Portillo (1982).

Es un hecho relevante que los libros de Fuentes Mares causaron escándalos y polémica en la época de su publicación porque analizaba a los personajes históricos como el presidente Benito Juárez y el terrateniente Luis Terrazas con una visión que contradice la historia oficial. El investigador Luis Aboites refiere la polémica que se generó entre Fuentes Mares y otro

142 Nota introductoria, en Fuentes Mares, José, Arte del bien comer y del mejor beber, México, Fondo de Cultura Económica, 2000, p. 3. 
Este libro forma parte del acervo de la Biblioteca Jurídica Virtual del Instituto de Investigaciones Jurídicas de la UNAM

historiador Chihuahuense, Francisco Almada, por el tratamiento que el primero dio a los personajes referidos. También menciona como un hecho relevante que durante la breve gestión de Fuentes Mares en la rectoría de la Universidad Autónoma de Chihuahua logró que José Vasconcelos visitara el estado norteño, dos meses antes del fallecimiento de éste, la amistad entre ambos nació a raíz de la publicación de Poinsett, historia de una gran intriga, libro que agradó en demasía al abogado oaxaqueño. ${ }^{143}$

En su juventud José Fuentes Mares realizó importantes estudios sobre filosofía, me refiero a Kant y la evolución de la conciencia socio-política moderna (UNAM, 1946); así como un prólogo titulado Gabino Barreda, publicado en 1940 por la UNAM, en la colección Biblioteca del Estudiante Universitario (número 26), en el cual nos informa que tan importante personaje concluyó sus estudios de abogacía, pero que rechazó la obtención del título porque le interesaba el estudio de temas muy concretos, por lo cual pasó al Colegio de Minería a estudiar química, posteriormente realizaría la carrera de medicina, y partiría a Francia a escuchar las conferencias dictadas por Augusto Comte sobre

143 Aboites Aguilar, Luis, "José Fuentes Mares y la historiografía del norte de México. Una aproximación desde Chihuahua (1950-1957)", Historia Mexicana, México, vol. XLIX, núm. 3, enero-marzo de 2000, pp. 477-507. 
Este libro forma parte del acervo de la Biblioteca Jurídica Virtual del Instituto de Investigaciones Jurídicas de la UNAM

filosofía positivista. ${ }^{144}$ Fuentes Mares seleccionó para este volumen varios textos que reflejan las ideas más sobresalientes de don Gabino Barreda (1818-1881) en materia de educación y cultura, dichos textos son una carta de Barreda al gobernador del Estado de México, Mariano Riva Palacio, sobre temas de instrucción preparatoria; la famosa Oración cívica pronunciada por Barreda el 16 de septiembre de 1867, en Guanajuato; el artículo denominado "De la educación moral", publicado en el periódico El Siglo XIX, el 3 de mayo de 1863; un discurso de Barreda En honor del barón de Humboldt, pronunciado el 14 de septiembre de 1869; y un discurso de Barreda, a nombre de la Escuela Nacional Preparatoria, en honor al pintor Juan Cordero, en gratitud por el mural con el que embelleció su edificio.

El historiador chihuahuense también incursionó en la literatura, redactó varias novelas como Servidumbre (1962). Además escribió un libro sobre cocina, denominado Nueva guía de descarriados, publicado en 1977. Realizó su autobiografía que lleva por título Intravagario. Ejerció el periodismo en el suplemento Diorama de la Cultura del diario Excélsior. ${ }^{145}$ Fuentes Mares fue

144 Fuentes Mares, José, "Prólogo", en Gabino Barreda. Estudios, 4a. ed., México, UNAM, Colección Biblioteca del Estudiante Universitario, núm. 26, 2010, pp. VI y VII.

145 Muro, Luis, "Bibliografía de José Fuentes Mares", publicado en http://biblio-codex.colmex.mx/exlibris/aleph, consultado el 5 de julio de 2014. 
Este libro forma parte del acervo de la Biblioteca Jurídica Virtual del Instituto de Investigaciones Jurídicas de la UNAM

un pensador influido por diferentes corrientes políticas y culturales, pues en un tiempo fue partidario del franquismo el cual repudió posteriormente; también se distinguió como admirador de la nación española. En términos generales se posicionó como un historiador independiente cuyos libros fueron publicados por editoriales privadas como fus (de tendencia católica), y debe mencionarse que realizó estudios para el sector empresarial neoleonés como "Don Eloy S. Vallina" (1968) y "Monterrey. Una ciudad creadora y sus capitanes" (1976).

José Fuentes Mares formó parte de la Academia Mexicana de Historia, a la cual ingresó en septiembre de 1975 presentando el discurso titulado "Mi versión de la historia". De igual forma, a partir de 1955, fue miembro correspondiente de la Academia Mexicana de la Lengua. La producción de obras históricas realizadas por Fuentes Mares ha sido motivo de análisis por parte de otros investigadores, quienes han subrayado que el chihuahuense hizo grandes aportaciones para el conocimiento de las relaciones internacionales de México, ya que observaba que la posición geográfica de nuestro país propiciaba relaciones sui generis con Estados Unidos de Norteamérica y Estados europeos. ${ }^{146}$

146 Villalpando César, José Manuel, "José Fuentes Mares, historiador mexicano", Estudios de Historia Moderna y Contemporánea de México, México, vol. 12, 1989, pp. 189-208. 
Este libro forma parte del acervo de la Biblioteca Jurídica Virtual del Instituto de Investigaciones Jurídicas de la UNAM

La Universidad Autónoma de Ciudad Juárez instituyó el "Premio Nacional de Literatura José Fuentes Mares", en 1985. Este premio se otorga anualmente a algún escritor mexicano sobresaliente que cultive los géneros de poesía, cuento o novela en español. Entre los galardonados con el premio se encuentran Carlos Montemayor, José Emilio Pacheco y Juan Villoro.

Con motivo de la celebración de los 25 años de instauración de dicho Premio Nóesis. Revista de Ciencias Sociales y Humanidades de la mencionada universidad dedicó su número 40 al análisis de la obra del historiador chihuahuense.

\section{RUBÉN BONIFAZ NUÑO}

Nació en Córdoba, Veracruz el 12 de noviembre de 1923, falleció en la Ciudad de México el 31 de enero de 2013. Bonifaz Nuño realizó todos sus estudios en la Universidad Nacional Autónoma de México. Obtuvo el título de licenciado en derecho en 1949, presentando la tesis El convenio de transacción (Escuela Nacional de Jurisprudencia). En 1968 recibió el grado de maestro en letras clásicas, defendiendo la tesis Los carmenes de Cayo Valerio Catulo (Facultad de Filosofía y Letras). En 1970 se doctoró en letras con la tesis Virgilio: La Eneida: libros I-VI (Facultad de Filosofía y Letras). ${ }^{147}$

147 Información de las tesis fue localizada en la base de datos Tesiunam, consultada en octubre de 2014. 
Este libro forma parte del acervo de la Biblioteca Jurídica Virtual del Instituto de Investigaciones Jurídicas de la UNAM

En su alma máter, la Universidad Nacional Autónoma de México, desarrolló una intensa actividad docente y de investigación, además de ser el impulsor de la creación de programas editoriales y entidades académicas que aún continúan operando, en este último renglón fue fundador, en 1966, del Centro de Traductores de Lenguas Clásicas (hoy Centro de Estudios Clásicos), el cual se incorporó al Instituto de Investigaciones Filológicas, creado también por iniciativa de Bonifaz Nuño en 1973;148 desde este año hasta 1985 el abogado y poeta Bonifaz ocupó la dirección de dicho Instituto. Dentro de las áreas administrativas de la Universidad Nacional desempeñó cargos tan relevantes como el de coordinador de Humanidades, director del Seminario de Estudios de Descolonización de México. Por otra parte, fue miembro de la Junta de Gobierno (1987-1993).

Sus inicios en la administración universitaria fueron como jefe de redacción de la Dirección General de Información (1954-1955) y en calidad de secretario de la Dirección General de Publicaciones (1955-1956), esta última la dirigió en el periodo 1962-1966. Bonifaz Nuño intervino con fortuna en diferentes actividades editoriales ya que se desempeñó como director de la Colección Nuestros Clásicos, de 1971 a 1981, además

148 Véase wrwre.ïfilologicas.unam.mx/index.php?page, consultada en septiembre de 2015. 
Este libro forma parte del acervo de la Biblioteca Jurídica Virtual del Instituto de Investigaciones Jurídicas de la UNAM

formó parte de la Junta Directiva de Cuadernos Americanos (1966-1986) y de la Junta de Gobierno del Fondo de Cultura Económica (1977-1984).

El doctor Rubén Bonifaz ocupó el cargo de coordinador de Humanidades en dos ocasiones, de 1966 a 1977 y de 1980 a 1981. Inició su carrera como docente de esta casa de estudios (la UNAM) desde 1960, en la Facultad de Filosofía y Letras. En 1966 se incorporó como investigador de carrera en el Instituto de Investigaciones Históricas donde trabajó hasta 1973 por integrarse al Instituto de Investigaciones Filológicas. ${ }^{149}$

Su producción literaria comprende libros de poesía y ensayos, además fue intensísima su labor de traductor de los clásicos griegos y latinos, así como creador de múltiples estudios introductorios de éstos. En la Universidad Nacional Autónoma de México fue director y fundador de la Bibliotheca Scriptorum Graecorum et Romanorum Mexicana. Bonifaz Nuño destacó también por sus trabajos de análisis de la obra plástica prehispánica. En este último tema don Rubén publicó los libros Imagen de Tláloc, hipótesis iconográfica y textual, ${ }^{150}$ Olmecas: esencia y fundación. Hipótesis icono-

149 Información obtenida en http://wrerr.humanidades.unam.mx, consultada en septiembre de 2015.

150 Bonifaz Nuño, Rubén, Imagen de Tláloc, hipótesis iconográfica y textual, México, UNAM, Coordinación de Humanidades, 1996. 
Este libro forma parte del acervo de la Biblioteca Jurídica Virtual del Instituto de Investigaciones Jurídicas de la UNAM

gráfica y textual ${ }^{151}$ y El Museo Amparo. Colección prehispánica. ${ }^{152}$

En la Bibliotheca Scriptorum Graecorum et Romanorum Mexicana Bonifaz Nuño publicó las traducciones de las Geórgicas, las Bucólicas y la Eneida de Virgilio; el Arte de amar y la Metamorfosis de Ovidio; Cármenes de Catulo; Sátiras de Horacio; la Guerra Gálica de Julio César; A cerca de los deberes de Cicerón; la Ilíada de Homero; Hipólito de Eurípides, entre otras grandes obras de la literatura grecolatina.

Rubén Bonifaz Nuño incursionó en el estudio de la cultura mexicana en sus aspectos generales, es de destacar su afición por temáticas diversas, lo mismo valoró la producción literaria novohispana del franciscano Fray Diego Valadés, que las composiciones para niños de Gabilondo Soler, Cri-Cri (siglo XX). Del primer personaje realizó un estudio introductorio para el libro Acerca de Fray Diego Valadés, su retórica cristiana. ${ }^{153}$ En tanto que sobre el popular compositor de Caminito de la Escuela, don Rubén ofreció un artículo en la Revista de la Universidad de México en el cual recrea el México de la

151 Bonifaz Nuño, Rubén, Olmecas: esencia y fundación. Hipótesis iconográfica y textual, México, El Colegio Nacional, 1992.

152 Bonifaz Nuño, Rubén, El Museo Amparo. Colección prehispánica, México, Museo Amparo, 1993.

153 Bonifaz Nuño, Rubén, "Introducción”, en Reyes Coria, Bulmaro et al., Acerca de fray Diego Valadés, su retórica cristiana, México, UNAM, 1996. 
Este libro forma parte del acervo de la Biblioteca Jurídica Virtual del Instituto de Investigaciones Jurídicas de la UNAM

década de los treinta donde niños y adultos se deleitaban con la magia de la radiodifusión (principalmente la de la XEW), y destaca el valor artístico de las composiciones de Gabilondo Soler. Nos recuerda el poeta Bonifaz que: "En aquel tiempo, afortunadamente, no había televisión, de manera que las imágenes formadas al escuchar las canciones eran creación de nosotros mismos: así las encuentro hoy por dentro de mí". ${ }^{154} \mathrm{La}$ muerte, tema recurrente en la cultura mexicana fue recreado por Bonifaz en su libro de poesía denominado Calacas, mismo que inicia con este verso

Adelanta la pantomima:

Igual que a las torres de los reyes

$\mathrm{Y}$ a los jacales de los pobres,

Con equitativo pie a mi puerta, tin tin, está llamando ahora;

sé quién es, tin tin, y me resisto

a abrirle, y estoy, tin tin, abriéndole.

\section{II}

En tu frente de azúcar llevas

un letrero: mi nombre. Muerdes

un regusto hipócrita a tristeza

con tu risa inmóvil y ostentosa.

154 Bonifaz Nuño, Rubén, "Poesía de Gabilondo Soler a sus cien años", Revista de la Universidad de México, México, núm. 46, diciembre de 2007. 
Este libro forma parte del acervo de la Biblioteca Jurídica Virtual del Instituto de Investigaciones Jurídicas de la UNAM

\section{Hospitalaria, así te ofrendan}

con los huesos de tu pan, el gualda

de tu cempasúchil importado. ${ }^{155}$

En lo referente a la producción de Bonifaz, en el género de la poesía, la Universidad Nacional Autónoma de México honró la creatividad de este autor publicando un volumen el cual contiene versos como "Para los que llegan a las fiestas", "Semillas del placer, la muerte", "Eurídice", "Abre sus hojas de oro la paloma" y "Hay un asombro de silencio". La selección y nota introductoria de este texto fue realizada por el escritor Carlos Montemayor. ${ }^{156}$

Rubén Bonifaz Nuño se convirtió en académico de la Lengua en 1963, ocupó la silla V, su discurso de ingreso se denominó "Destino del canto". La respuesta al discurso la realizó don Agustín Yáñez. Bonifaz Nuño se separó de este organismo en 1996, por renuncia. Entre las actividades que efectuó en la Academia se encuentra la respuesta que dio al discurso de ingreso del escritor chihuahuense Carlos Montemayor, en 1985.

Rubén Bonifaz tuvo la distinción de ser miembro del Colegio Nacional, al que se incorporó el 20 de julio

155 Bonifaz Nuño, Rubén, Calacas, México, Fondo de Cultura Económica, 2012, pp. 11 y 12.

156 Montemayor, Carlos, "Nota introductoria", Material de lectura. Rubén Bonifaz Nuño, México, UNAM, Coordinación de Difusión Cultural, 2008, Colección poesía moderna, núm. 23. 
Este libro forma parte del acervo de la Biblioteca Jurídica Virtual del Instituto de Investigaciones Jurídicas de la UNAM

de 1972, y el 3 de noviembre del mismo año pronunció su conferencia inaugural titulada La fundación de la ciudad, en esta obra Bonifaz plantea que el ser humano de todas las latitudes realiza una obra de colaboración con el universo en los momentos en que decide fundar las ciudades, porque los lugares geográficos ya existen desde tiempos inmemoriales, pero el hombre en el acto de fundación realiza "una ampliación de la conciencia, un acontecimiento interior que confirma el orden del mundo externo". Lo mismo sea Roma o Chichen Itzá. Las comunidades, dice Bonifaz, tienen como elemento básico de cohesión la unidad del idioma. Para realizar estas afirmaciones el maestro Bonifaz Nuño hace una interpretación de obras clásicas de la literatura mundial como la Eneida y el Chilam Balam. ${ }^{157}$

Se le reconoció con las distinciones de investigador emérito de la UNAM, en 1989, e investigador emérito nacional en 1992. Además recibió el Premio Nacional de Letras (1974), el Premio Latinoamericano de Letras Rafael Heliodoro Valle (1980), fue doctor honoris causa por la Universidad Veracruzana y la Universidad de Colima. En 1990 recibió el Premio Universidad Nacional. También fue becario de la Fundación Guggenheim de 1984 a 1985, dando como fruto de

157 Bonifaz Nuño, Rubén, La fundación de la ciudad, conferencia inaugural en El Colegio Nacional, México, El Colegio Nacional, pp. 161-163, en wrerce.colegionacional.org.mx, consultado en septiembre de 2015 . 
Este libro forma parte del acervo de la Biblioteca Jurídica Virtual del Instituto de Investigaciones Jurídicas de la UNAM

esta distinción el libro Imagen de Tláloc, hipótesis iconográfica y textual.

En 1974, con motivo de la obtención del Premio Nacional en Letras Bonifaz Nuño pronunció un discurso titulado "Libertad y justicia", el cual resulta valioso porque narra la forma en que, desde el estudio del derecho romano, fue construyendo su carrera académica en diversos campos de las humanidades. Es esta una pieza oratoria en la que su autor ensalza la labor de la Universidad Nacional Autónoma de México para liberar de la ignorancia al pueblo y acercar a la sociedad a la obtención de la justicia, de este discurso son sobresalientes los siguientes fragmentos:

Guando hace muchos años, capacitado por mis estudios primarios, secundarios y preparatorianos en escuelas oficiales, ingresé en la Nacional de Jurisprudencia, tuve un encuentro para mí, de significación definitiva: el del espíritu y la lengua de Roma contenidos en sus construcciones jurídicas. Quizás ese estudio del Derecho Romano fue lo que vino a orientar lo mejor de las manifestaciones de mi vida. Porque mediante él empecé a comprender qué es lo que puede constituir al hombre en sí mismo, y darle la manera de que se desarrolle junto con los demás.

Entonces aprendí lo que es la justicia: aquella voluntad constante y perpetua de dar a cada quien su derecho. Es decir, no un pensamiento teórico ni un imperativo emotivo, sino una voluntad de contenido 
Este libro forma parte del acervo de la Biblioteca Jurídica Virtual del Instituto de Investigaciones Jurídicas de la UNAM

moral; y una voluntad que no admite tregua, porque es constante, y que carece de término, porque es perpetua.

Todo cuanto más tarde he leído de los escritores de Roma, todo cuanto he vivido, me ha confirmado, directamente, la validez universal de ese principio y me ha concedido los instrumentos para explicarme el significado de la vida humana, y el sentido del mundo que el hombre está obligado a construir...

Ahora bien: la justicia no es concebible sin la independencia, y la independencia no puede darse en la ignorancia. Que el hombre se haga independiente con respecto de la ignorancia, se presenta como la meta primera que debe ser pretendida. Una vez alcanzada, las demás formas de la independencia habrán de venir fatalmente y de suyo. El vencimiento de la ignorancia traerá pues, consigo, la conquista de los derechos y la posibilidad de lograr, con su cumplimiento, las transformaciones sociales conducentes a un porvenir de severa dignidad, porque la dignidad puede fincarse solamente en el conocimiento. ${ }^{158}$

\section{En 1996 el Fondo de Cultura Económica publicó} la obra poética de don Rubén Bonifaz Nuño en la

158 El discurso aparece publicado con el título "Palabras de Rubén Bonifaz Nuño, al recibir de manos del señor presidente de la República, licenciado Luis Echeverría Álvarez, el Premio Nacional de Letras de 1974, en el auditorio del Museo Nacional de Antropología, el 28 de noviembre de 1974", en http://colegionacional.org.mx, consultado el 19 de septiembre de 2015. 
Este libro forma parte del acervo de la Biblioteca Jurídica Virtual del Instituto de Investigaciones Jurídicas de la UNAM

Colección Letras Mexicanas (en dos volúmenes);159 hoy la misma editorial pone al alcance de los lectores la poesía completa de este autor con otro volumen denominado Calacas, los tres precedidos por un tomo con un estudio introductorio de la autoría de Luis García Montero, ${ }^{160}$ estos dos últimos se publicaron en el 2012.

Después de su fallecimiento se realizaron diferentes homenajes póstumos en las instituciones a las cuales perteneció. Entre los reconocimientos efectuados en la UNAM destacó la edición de marzo de 2013, de la Revista de la Universidad de México, misma que publicó textos de destacados intelectuales que trabajaron con Bonifaz Nuño en las diferentes modalidades ejercidas por el abogado veracruzano. Entre estas remembranzas Bulmaro Reyes Coria describió las particularidades del trabajo de Rubén Bonifaz en el campo de la filología, el poeta mexicano al realizar traducciones procuraba respetar la literalidad de los textos para brindar a los lectores versiones confiables. Reyes Coria describe el valor de los trabajos de introducción a las obras clásicas realizadas por Bonifaz:

159 Bonifaz Nuño, Rubén, De otro modo lo mismo, México, Fondo de Cultura Económica, 1996. Bonifaz Nuño, Rubén, Versos (19781994), México, Fondo de Cultura Económica, 1996.

160 García Montero, Luis, La poesía como destino. Prólogo a la obra de Rubén Bonifaz Nuño, México, Fondo de Cultura Económica, 2012. 
Este libro forma parte del acervo de la Biblioteca Jurídica Virtual del Instituto de Investigaciones Jurídicas de la UNAM

Los lectores de sus introducciones reciben doble beneficio: la enseñanza confiable de la vida y la obra de los clásicos estudiados por Bonifaz Nuño, y de regalo el placer de la lectura. Ahí se descubre el poder de la literatura sobre la vida humana y la influencia del escritor sobre el desarrollo de la sociedad, pues Bonifaz pone ante los ojos la vida misma, la injusticia, el dolor de la juventud, las obligaciones y limitaciones de la vejez, la débil naturaleza humana, y con frecuencia lo hace de la mano de la poética aristotélica, la cual conduce al poeta a invertir el mundo a placer y a recrearlo no como es en la realidad sino como el poeta quiere que sea. ${ }^{161}$

Por otra parte, el jurista Diego Valadés rindió un homenaje al abogado y literato veracruzano a través de una conferencia dictada, en 2014, en El Colegio Nacional publicada con el título "Rubén Bonifaz Nuño: el interlocutor perpetuo", en el cual se destaca el compromiso de este personaje con la defensa de los valores de la Universidad Nacional Autónoma de México a la cual consideraba "la conciencia del país". ${ }^{162}$

161 Reyes Coria, Bulmaro, "Bonifaz el filólogo, está bien”, Revista de la Universidad de México, México, núm. 109, marzo de 2013, p. 28.

162 Valadés, Diego, Perfiles académicos, México, Academia Mexicana de la Lengua, 2015, p. 11. 
Este libro forma parte del acervo de la Biblioteca Jurídica Virtual del Instituto de Investigaciones Jurídicas de la UNAM

\section{EMILIO Ó. RABASA}

Su nombre completo fue Emilio Óscar Rabasa Mishkin. Nació en la Ciudad de México, el 23 de enero de 1925, falleció en esta misma ciudad en 2008. Fue nieto del constitucionalista chiapaneco Emilio Rabasa Estebanell (1856-1930).

Estudió la carrera de derecho en la Universidad Nacional Autónoma de México, donde obtuvo el título respectivo en 1948 defendiendo la tesis La intervención del Estado en el crédito. ${ }^{163}$ Obtuvo el grado de doctor en derecho en 1957 en la misma universidad con la tesis El pensamiento político del constituyente de 1824.

De 1943 a 1948 se desempeñó en el Departamento de Bancos, Moneda e Inversiones de la Secretaría de Hacienda y Crédito Público, posteriormente fue jefe del departamento jurídico del Banco Nacional de Crédito Ejidal. ${ }^{164}$ En la administración del presidente Gustavo Díaz Ordaz fue director del Banco Nacional Cinematográfico (1969-1970). En 1970, durante breves meses se desempeñó como embajador de México en Estados Unidos de Norteamérica.

Posteriormente fue designado secretario de Relaciones Exteriores durante la mayor parte del gobier-

163 Véase Catálogo Tesiunam, consultada en mayo de 2014.

164 Cárdenas, Héctor, "Emilio O. Rabasa", en Galeana, Patricia (coord.), Cancilleres de México, siglo XX, México, Secretaría de Relaciones Exteriores, 1992, p. 399. 
Este libro forma parte del acervo de la Biblioteca Jurídica Virtual del Instituto de Investigaciones Jurídicas de la UNAM

no del presidente Luis Echeverría (1o. de diciembre de 1970 al 28 de diciembre de 1975). En su gestión como secretario de Relaciones Exteriores se habilitó el exconvento de Tlatelolco para albergar el Acervo Histórico Diplomático de México. ${ }^{165}$ También se fundó el Instituto Matías Romero ${ }^{166}$ (a principios de 1975) con la finalidad de crear un centro educativo en el cual recibieran formación profesional rigurosa los diplomáticos mexicanos. En la actualidad dicho Instituto continúa funcionando como un órgano desconcentrado de la Secretaría de Relaciones Exteriores; de acuerdo con el Reglamento Interior de esta Secretaría el Instituto Matías Romero tiene las funciones de formar a los miembros del Servicio Exterior Mexicano en materia de política exterior y relaciones internacionales, así como de habilidades de la negociación internacional y capacidad de análisis para enfrentar los retos de la labor diplomática contemporánea. Durante la administración de Rabasa se efectuó en la Ciudad de México, en 1975, la primera Conferencia Mundial sobre la Condición Jurídica y Social de la Mujer, además México estable-

165 Información obtenida en "Cancilleres de México. Siglo XX", en wrere.sre.gob.mx, consultada el 17 de junio de 2014.

166 Sobre la trascendencia histórica de este instituto véase, Gutiérrez Nieto, Guillermo, "Instituto Matías Romero: 40 años forjando diplomáticos", Siempre!, México, 10 de enero de 2015. 
Este libro forma parte del acervo de la Biblioteca Jurídica Virtual del Instituto de Investigaciones Jurídicas de la UNAM

ció relaciones diplomáticas con la República Popular China (1972). ${ }^{167}$

En este sexenio la participación de México en la diplomacia mundial fue muy relevante, precisamente al canciller Rabasa le correspondió atender los asuntos relativos al asilo que nuestro país otorgó a los ciudadanos chilenos que huyeron tras el golpe militar del presidente Salvador Allende, de igual forma en este lapso México se negó a aplicar las sanciones impuestas a Cuba por la Organización de los Estados Americanos (OEA). El abogado Rabasa promovió durante su encargo al frente de la Secretaría de Relaciones Exteriores mejoras salariales y otras prestaciones para los integrantes del cuerpo diplomático mexicano.

Emilio O. Rabasa intervino en la creación de la Carta de derechos y deberes económicos de los Estados, y gestionó su adopción por la Organización de las Naciones Unidas (ONU). Fue también de gran trascendencia la participación de Rabasa en las gestiones para la promoción de la figura de la zona económica exclusiva de hasta 200 millas náuticas. Rabasa renunció en 1975 al cargo de secretario de Relaciones Exteriores, porque estuvo en desacuerdo con la política del presidente Luis Echeverría en relación con el conflicto árabe-israelí. El

167 Sobre la política exterior de México durante el régimen de Luis Echeverría véase, Covarrubias, Ana, "La política exterior «activa»...una vez más", Foro Internacional, México, vol. 68, núms. 1 y 2, 2008, pp. 13-34. 
Este libro forma parte del acervo de la Biblioteca Jurídica Virtual del Instituto de Investigaciones Jurídicas de la UNAM

constitucionalista Rabasa se incorporó posteriormente al Grupo Mexicano de la Corte Permanente de Arbitraje de la Haya, y al Comité Jurídico Interamericano de la Organización de los Estados Americanos.

En la Universidad Nacional Autónoma de México trabajó con el rector Luis Garrido, a quien planteó la idea de crear la actual Facultad de Ciencias Políticas y Sociales. ${ }^{168}$ Se desempeñó como profesor en la Facultad de Derecho impartiendo la materia Teoría General del Estado. En años posteriores se incorporó como investigador al Instituto de Investigaciones Jurídicas donde efectuó diversas publicaciones, sobresaliendo los libros: El pensamiento político del Constituyente de 1824 (1986), El pensamiento politico y social del constituyente de 1916-1917 (1986), Historia de las Constituciones mexicanas (1990) y La evolución constitucional de México (2004). Por otra parte, don Emilio O. Rabasa nos legó interesantes comentarios respecto a las transformaciones constitucionales de México, los cuales constan en dos audiodiscos producidos por el Instituto de Investigaciones Jurídicas de la UNAM como parte de la colección Voz de nuestros juristas. ${ }^{169}$

Emilio O. Rabasa escribió interesantes artículos académicos como: "La participación de México en la

168 Garrido, Luis, El tiempo de mi vida. Memorias, México, Porrúa, 1974, p. 327.

169 Editado en 2005. 
Este libro forma parte del acervo de la Biblioteca Jurídica Virtual del Instituto de Investigaciones Jurídicas de la UNAM

fundación de la ONU y sus reformas", 170 "La zona económica exclusiva (artículo 27, párrafo octavo)", 171 "El caso Chiapas: aspecto constitucional", 172 "El pensamiento constitucional de Venustiano Carranza (análisis de su mensaje del 1o. de diciembre de 1916 al presentar el proyecto de Constitución)", ${ }^{173}$ "La política exterior de México en sus Constituciones", 174 "El jurado popular en las Constituciones de 1857 y 1917. Antecedentes, secuencia y consecuencias", 175 "La Constitución de 1824: primer acto de autodeterminación mexicana". ${ }^{176}$

170 Publicado en el libro Un homenaje a don César Sepúlveda. Escritos jurídicos, México, UNAM, Instituto de Investigaciones Jurídicas, 1995, pp. 281-296.

171 Ochenta años de vida constitucional en México, México, UNAM, Instituto de Investigaciones Jurídicas, 1998, pp. 555 y 566.

172 En Melgar Adalid, Mario et al. (coords.), La rebelión de Chiapas y el derecho, México, UNAM, Instituto de Investigaciones Jurídicas, 1994, pp. 185-196.

173 Anuario Mexicano de Historia del Derecho, México, vol. VII, 1995, pp. 151-162.

174 Rabasa, Emilio O. (coord.), Los siete principios básicos de la politica exterior de México, México, UNAM, Instituto de Investigaciones Jurídicas, 2005, pp. 3-24.

175 Liber ad honorem Sergio García Ramírez, México, UNAM, Instituto de Investigaciones Jurídicas, 1998, pp. 555-577.

176 Valadés, Diego y Barceló, Daniel (coords.), Examen retrospectivo del sistema constitucional mexicano. A 180 años de la Constitución de 1824, México, UNAM, Instituto de Investigaciones Jurídicas, 2005, pp. 345-349. 
Este libro forma parte del acervo de la Biblioteca Jurídica Virtual del Instituto de Investigaciones Jurídicas de la UNAM

$\mathrm{Su}$ trayectoria académica fue reconocida con su incorporación al Sistema Nacional de Investigadores, y la Universidad Nacional Autónoma de México lo incluyó en el Programa de Primas al Desempeño del Personal Académico de Tiempo Completo (PRIDE). Tras el fallecimiento del abogado, el Instituto de Investigaciones Jurídicas de la UNAM realizó un libro colectivo en homenaje a la trayectoria política y académica del constitucionalista, coordinado por el doctor Jorge Carpizo y Carol B. Arriaga, quien fue asistente del doctor Emilio O. Rabasa. ${ }^{177}$ En marzo de 2011 Patricia Espinosa, entonces secretaria de Relaciones Exteriores, presentó la obra póstuma del ex canciller Rabasa, denominada Mis memorias como secretario de Relaciones Exteriores, 1970-1975.178

\section{LUIS JAVIER GARRIDO}

$\mathrm{Su}$ nombre completo era Luis Javier Garrido Platas. Nació en la Ciudad de México, el 9 de noviembre de 1941 y falleció en la misma ciudad en febrero de 2012. Realizó la carrera de derecho en la facultad de la Uni-

177 Carpizo, Jorge y Arriaga, Carol B. (coords.), Homenaje al doctor Emilio O. Rabasa, México, UNAM, Instituto de Investigaciones Jurídicas, 2010.

178 Publicada en México por la editorial Miguel Ángel Porrúa, en 2010 . 
Este libro forma parte del acervo de la Biblioteca Jurídica Virtual del Instituto de Investigaciones Jurídicas de la UNAM

versidad Nacional Autónoma de México, donde obtuvo el título en 1972, con la tesis Notas sobre la transformación política de México. ${ }^{179}$ Obtuvo una beca para estudiar en Francia donde realizó un diplomado de Estudios Superiores en Ciencia Política por la Sorbonne, posteriormente ingresó en la Panthéon-Sorbonne París I donde obtuvo el grado de doctor en Estado en ciencia política, ${ }^{180}$ para ello, bajo la dirección de Maurice Duverger, realizó una tesis sobre el Partido Revolucionario Institucional que se publicaría en México bajo el título de El Partido de la Revolución Institucionalizada, obra que se ha convertido en un estudio clásico sobre el sistema político mexicano. Especialistas en ciencia política han hecho notar que el principal mérito de esta obra de Garrido es analizar al Partido Revolucionario Institucional como una entidad partidista comparable a otras y no como una variable dependiente del Poder Ejecutivo Federal o del Estado. Esta obra "sugiere nuevas perspectivas de análisis y abre la puerta a un muy deseable revisionismo histórico". ${ }^{181}$

179 Información obtenida en http://oreon.dgbiblio.unam.mx/F, consultada el 13 de mayo de 2015.

180 Garrido, Luis Javier, El Partido de la Revolución Institucionalizada, 7a. ed., México, Siglo XXI Editores, 1995.

181 Loaeza, Soledad, "En el principio fue el PRI", Nexos, México, febrero de 1984, en wrerrenexos.com.mx, consultada en mayo de 2015 . 
Este libro forma parte del acervo de la Biblioteca Jurídica Virtual del Instituto de Investigaciones Jurídicas de la UNAM

Luis Javier Garrido ejerció la docencia en la Escuela Nacional Preparatoria, en la Facultad de Derecho y en el posgrado de la Facultad de Ciencias Políticas y Sociales de la Universidad Nacional Autónoma de México, donde impartió la asignatura Partidos políticos y gobernabilidad. Dentro de esta universidad ocupó la plaza de investigador en el Instituto de Investigaciones Sociales, contando con la distinción de ser integrante del Sistema Nacional de Investigadores, con nivel III.

Desde 1984 hasta su fallecimiento ejerció el periodismo en el diario La fornada, en el cual publicaba, una vez por semana, editoriales sobre sucesos políticos de actualidad. Se caracterizó por sus posiciones de izquierda, fue defensor de los movimientos de oposición al régimen priista, por lo cual se convirtió en asesor del Ejército Zapatista de Liberación Nacional (EZLN) que surgió en la escena pública en enero de 1994.

Durante la suspensión de labores de la Universidad Nacional Autónoma de México (1999-2000) Luis Javier Garrido respaldó al Consejo General de Huelga como asesor. ${ }^{182}$ En 2007 un grupo de estudiantes de la Facultad de Economía de la UNAM apoyó al doctor

182 Las opiniones de Garrido sobre el movimiento se pueden consultar en Camarillo, María Teresa y Curiel, Guadalupe (coords.), Hemerografia del movimiento estudiantil universitario (19992000), México, UNAM, Instituto de Investigaciones Bibliográficas, 2005, pp. 332, 339 y 345. 
Este libro forma parte del acervo de la Biblioteca Jurídica Virtual del Instituto de Investigaciones Jurídicas de la UNAM

Garrido para que ocupara la rectoría de dicha casa de estudios, ${ }^{183}$ incluso el abogado y politólogo llegó a ser entrevistado por la Junta de Gobierno, pero resultó electo el doctor José Narro Robles.

Garrido Platas escribió el libro La ruptura. La corriente democrática del PRI, sobre la escisión de priístas en 1987 de la cual surgió el Partido de la Revolución Democrática, este libro fue escrito con el apoyo de la John Guggenheim Memorial Foundation. Esta obra es una contribución valiosa sobre la historia política de México a finales del siglo XX, contiene una muy amplia información sobre el proceso de sucesión del presidente Miguel de la Madrid, el cual se caracterizó por la demanda de algunos militantes priistas para democratizar la elección del candidato del Partido Revolucionario Institucional a ocupar el Poder Ejecutivo Federal al término del mandato del presidente De la Madrid. El politólogo Luis Javier Garrido analizó dicho proceso sucesorio desde octubre de 1985 hasta diciembre de 1987. La ruptura. La corriente democrática del PRI es un trabajo sólidamente fundamentado en hemerografia, documentos de archivo y fuentes orales, además está ilustrado con un amplio acervo fotográfico, lo cual incrementa su valor explicativo de la historia reciente de México. Garrido concluye esta obra con las siguientes ideas:

183 Notimex, "Destapan a Luis Javier Garrido para dirigir la UNAM", El Universal, México, 17 de octubre de 2007. 
Este libro forma parte del acervo de la Biblioteca Jurídica Virtual del Instituto de Investigaciones Jurídicas de la UNAM

En un partido de Estado como el PRI mexicano, sometido a la autoridad presidencial, no podían tener cabida las corrientes organizadas, en particular cuando eran realmente eso, expresiones independientes dentro de la pluralidad orgánica que debería ser un partido político, y por una razón: tendían inevitablemente a reivindicar los derechos de los militantes y a poner un límite al poder presidencial sobre el Partido.

La disidencia concluyó así, a fin de cuentas, en las luchas por democratizar a México. El episodio de la Corriente Democrática del PRI (1986-1987) resultó un hito en la historia mexicana de finales del siglo XX ya que abrió una brecha en el "sistema" de gobierno instaurado en 1929, la que lejos de cerrarse se fue haciendo cada vez más honda. La iniciativa de ese puñado de mexicanos configuró la más importante escisión en el PRI en cuatro décadas, quitó el cerrojo a la campaña histórica de 1988 e incidió de manera decisiva en los años siguientes en la correlación de fuerzas políticas del país. "La Corriente", así sin más, como se le llamó, permitió confirmar que la transición a la democracia no podía venir sino de la crítica con los hechos al presidencialismo mexicano. ${ }^{184}$

Luis Javier Garrido tuvo afinidad intelectual con el norteamericano Noam Chomsky para quien escribió la introducción al libro La sociedad global. Educación, mer-

184 Garrido, Luis Javier, La ruptura. La corriente democrática del PRI, México, Grijalbo, 1993, pp. 198 y 199. 
Este libro forma parte del acervo de la Biblioteca Jurídica Virtual del Instituto de Investigaciones Jurídicas de la UNAM

cado y democracia, ${ }^{185}$ y el prólogo del libro Noam Chomsky habla de América latina y México. ${ }^{186}$ Garrido también fue profesor y conferencista en las universidades de Texas, de California, de Barcelona y la Complutense de Madrid. En 2004 el doctor Garrido participó en una consulta convocada por la Cámara de Diputados federal y la Universidad Nacional Autónoma de México, entregando la ponencia denominada "El respeto a la Constitución”, la cual concluyó con el siguiente texto:

Esto debería ser entendido por los legisladores: que si las cámaras federales no cumplen su cometido, también como lo vieron Locke y Montesquieu, es el poder del pueblo el que va a detener al poder, por muy poderoso que éste pretenda ser. ${ }^{187}$

Posteriormente a su fallecimiento, en 2012, la Universidad Nacional Autónoma de México publicó el

185 Garrido, Luis Javier, "Introducción", en Chomsky, Noam y Dieterich, Heinz, La sociedad global. Educación, mercado y democracia, México, Joaquín Mortiz, 1995.

186 Garrido, Luis Javier, "Prólogo", en Dietrich, Heinz (entrevistador), Noam Chomsky habla de América latina y México, México, Océano, 1998.

187 Garrido, Luis Javier, "El respeto a la Constitución”, en Camacho Solís, Manuel y Valadés, Diego (coords.), Gobernabilidad democrática: ¿Qué reforma?, México, Cámara de Diputados, LIX Legislatura-UNAM, Instituto de Investigaciones Jurídicas, 2004, pp. 269-276. 
Este libro forma parte del acervo de la Biblioteca Jurídica Virtual del Instituto de Investigaciones Jurídicas de la UNAM

volumen de homenaje Luis Favier Garrido Platas (19412012). Ante todo: un universitario, en el cual aparecen textos de Estela Morales Campos (coordinadora de Humanidades de la UNAM), Rosalba Casas Guerrero (directora del Instituto de Investigaciones Sociales de la UNAM), Fernando Castañeda Sabido (director de la Facultad de Ciencias Políticas y Sociales de la UNAM), y de los profesores universitarios Octavio Rodríguez Araujo, Hugo Casanova Cardiel, Raúl Carrancá y Rivas, y Álvaro Arreola Ayala. ${ }^{188}$

\section{Garlos Montemayor}

Su nombre completo fue Carlos Antonio Montemayor Aceves. ${ }^{189}$ Nació en Parral, Chihuahua, el 13 de junio de 1947, falleció en la Ciudad de México el 28 de febrero de 2010. Realizó sus estudios de derecho en la Universidad Autónoma de Chihuahua. Aprendió lengua hebrea en el Colegio de México. En la Facultad de Filosofía y Letras de la Universidad Nacional Autónoma de México hizo la carrera de letras iberoamericanas.

Fue profesor de Ética y Estética en la Escuela Nacional Preparatoria. De 1973 a 1975 se desempeñó

188 Luis Favier Garrido Platas (1941-2012): ante todo: un universitario, México, UNAM, Coordinación de Humanidades, 2012.

189 Información obtenida a través de la página electrónica de la Cátedra Carlos Montemayor, en http://catedracarlosmontemayororg. 
Este libro forma parte del acervo de la Biblioteca Jurídica Virtual del Instituto de Investigaciones Jurídicas de la UNAM

como jefe de redacción de la Revista de la Universidad de México. En 1974 ingresó como profesor de tiempo completo en la Universidad Autónoma Metropolitana, Unidad Azcapotzalco, adscrito al departamento de Humanidades. En dicha universidad ocupó el cargo de director general de Difusión Cultural, en el periodo de noviembre de 1979 a septiembre de 1982.

Cultivó diferentes géneros literarios, sus obras reflejaban las preocupaciones de Montemayor por los problemas sociales de México, especialmente las condiciones de vida de los indígenas y el desarrollo de los movimientos guerrilleros de nuestro país. Sobre la problemática de los indígenas escribió varios cuentos como Las llaves de Urgell (1971) y Los dioses perdidos (1979). ${ }^{190}$ En el plano jurídico fue de gran importancia el peritaje que realizó Carlos Montemayor para el juicio que efectuó la Corte Interamericana de Derechos Humanos sobre el caso Radilla Pacheco contra los Estados Unidos Mexicanos, dicho peritaje se tituló "La violencia de Estado en México durante la llamada guerra sucia del siglo XX". ${ }^{191}$

190 Mateos Vega, Mónica, "Carlos Montemayor deja una vida de creación y compromiso", La fornada, México, lo. de marzo de 2010 , p. 2.

191 El peritaje aparece publicado en La sentencia de la Corte IDH. Caso Radilla Pacheco vs. Estados Unidos Mexicanos, México, Comisión Mexicana de Defensa y Promoción de los Derechos Humanos, 2010, pp. 21-39. 
Este libro forma parte del acervo de la Biblioteca Jurídica Virtual del Instituto de Investigaciones Jurídicas de la UNAM

Entre las múltiples acciones que realizó a favor de la preservación y difusión de las lenguas indígenas de México se encuentra la antología que elaboró, conjuntamente con Donald H. Frischmann, titulado Los nuevos cuentos de la ceiba, ${ }^{192}$ edición triligüe (maya, español e inglés). También es de particular relevancia el libro Arte y plegaria en las lenguas indígenas de México, en el cual Montemayor enfatiza:

Debemos reiterar que las culturas indígenas de México permanecen vivas entre otras causas por el soporte esencial del idioma y por la función que éste desempeña en la ritualización de la vida civil, agrícola y religiosa. La relación entre ciertas zonas sociales de resistencia cultural y el uso ritual de la lengua aun en comunidades donde el bilingüismo se acrecienta es, repito, uno de los casos preclaros en que el idioma representa la vida misma de los pueblos...

Finalmente, que la tradición oral, entendida como un arte de composición, tiene funciones precisas, en particular la de conservar conocimientos ancestrales a través de cantos, rezos, conjuros, dis-

$192 U$ TUMBEN K'AAYILO'OB X-YA'AXCHE', U meyaj bejlabeno'ob maaya aj ts'ïbo'ob ti'u petenil Yúucataane' (Los nuevos cantos de la ceiba, antología de escritores mayas contemporáneos de la península de Yucatán), Montemayor, Carlos y Frischmann, Donald H. (antologadores), México, Gobierno de Yucatán, Instituto de Cultura de Yucatán, 2009. 
Este libro forma parte del acervo de la Biblioteca Jurídica Virtual del Instituto de Investigaciones Jurídicas de la UNAM

cursos o relatos, que transmiten y reflejan no solamente los cambios que las culturas indígenas han experimentado durante la Colonia y el México independiente, sino la persistencia del mundo religioso y artístico prehispánico. ${ }^{193}$

Un excelente libro de Montemayor sobre los pueblos originarios del estado de Chihuahua es Los Tarahumaras pueblo de estrellas y barrancas, ${ }^{194}$ el cual ha sido publicado en varias ocasiones por su excelente contenido. Los movimientos guerrilleros de México fue tema que llevó al escritor chihuahuense a realizar rigurosas investigaciones en archivos oficiales y obteniendo testimoniales de familiares y amigos de guerrilleros, información que dio fundamento a las novelas Guerra en el paraíso (1991) y Las armas del alba (2003);195 así como los ensayos Chiapas. La rebelión indígena en México y La guerrilla recurrente.

Entre otros trabajos destacados de Carlos Montemayor se encuentra la coordinación de un dicciona-

193 Montemayor, Carlos, Arte y plegaria en las lenguas indígenas de México, México, Fondo de Cultura Económica, 2001, p. 7.

194 Montemayor, Carlos, Los Tarahumaras pueblo de estrellas y barrancas, México, Editorial Aldus, 1999.

195 Esta novela fue llevada al cine por el director José Luis Urquieta, la película quedó concluida en el 2013 y se exhibió en la Cineteca Nacional, cuenta con las actuaciones de Ernesto Gómez Cruz y Aarón Hernán. 
Este libro forma parte del acervo de la Biblioteca Jurídica Virtual del Instituto de Investigaciones Jurídicas de la UNAM

rio de náhuatl ${ }^{196}$ y un artículo denominado "La pluma del escribano" que se creó para ser incluido en un libro en homenaje al escritor oaxaqueño Andrés Henestrosa. ${ }^{197}$

Las actividades intelectuales de Montemayor también se desarrollaron en el campo del periodismo, fue colaborador de la revista Plural (de Excélsior) y de los periódicos Unomásuno, La fornada y Excélsior. Fue fundador de la revista Casa del tiempo de la Universidad Autónoma Metropolitana (1980). También efectuó traducciones de los clásicos grecolatinos como Píndaro, Cayo Valerio Catulo, Safo y Virgilio. Desde la niñez tuvo especial inclinación hacia la música, aprendió a tocar la guitarra en su estado natal, en la edad adulta tomó clases de canto y grabó varios discos, en los cuales incluyó canciones de María Grever y Manuel M. Ponce, entre otros autores. ${ }^{198}$

Carlos Montemayor fue miembro de número de la Academia Mexicana de la Lengua a partir del 14

196 Montemayor, Carlos (coord.), Diccionario del náhuatl en el español de México, México, UNAM, Programa México Nación Multicultural-Gobierno del Distrito Federal, 2007.

197 Montemayor, Carlos, "La pluma del escribano", Cien años de Andrés Henestrosa, México, Fundación Sebastián, 2006, pp. 14-23.

198 Sobre esta faceta del escritor chihuahuense véase Bravo, Antonio, "Carlos Montemayor: voz que es carmen, que es canto", Casa del tiempo, México, núm. 13, febrero de 2015, pp. 24-26. 
Este libro forma parte del acervo de la Biblioteca Jurídica Virtual del Instituto de Investigaciones Jurídicas de la UNAM

de marzo de 1985, ocupando la silla XX, ${ }^{199}$ ocupó el lugar de don Antonio Castro Leal. Obtuvo los premios Javier Villaurrutia (1971), Juan Rulfo internacional otorgado por Radio Francia Internacional por el cuento Operativo en el trópico (1993), Nacional de Ciencias y Artes, en el Área de Lingüística y Literatura (2009); en 1995 fue declarado profesor emérito por la Universidad Autónoma de Ciudad Juárez.

En el Centro de Investigación y Docencia en $\mathrm{Hu}-$ manidades del estado de Morelos se fundó la Cátedra Intercultural Carlos Montemayor, coordinada por la psicóloga Laura Bensasson, esta cátedra tiene como objetivos la difusión del pensamiento de Carlos Montemayor, el fomento de la creación literaria en lenguas indígenas, la generación de propuestas alternativas para la enseñanza, divulgación y respeto de las lenguas y culturas indígenas. ${ }^{200}$

Desde 2004, en la Universidad Nacional Autónoma de México, Montemayor conjuntamente con el Programa México Nación Multicultural coordinó el Festival de Poesía las Lenguas Indígenas de América, a partir de 2010 al fallecer el escritor se agregó su nombre a las siguientes ediciones del Festival, ${ }^{201}$ el cual se efectúa

199 Véase wrerre. academia.org.mx, consultada el 4 de julio de 2014.

200 Véase http://catedracarlosmontemayororg.

201 Por acuerdo del rector José Narro Robles, publicado en la Gaceta UNAM, 11 de octubre de 2010. 
Este libro forma parte del acervo de la Biblioteca Jurídica Virtual del Instituto de Investigaciones Jurídicas de la UNAM

bianualmente y ha buscado ser una plataforma para el reconocimiento de las lenguas originarias del continente americano en la literatura contemporánea. ${ }^{202}$

\section{VÍGTOR Hugo RASCÓN BANDA}

Nació el 6 de agosto de 1948 en Santa Rosa de Lima, municipio de Uruáchi, Chihuahua. Lugar que se halla enclavado en la Sierra Tarahumara. El escritor chihuahuense falleció en la Ciudad de México, el 31 de julio de 2008.

Estudió la carrera de maestro en la Escuela Normal Superior de Chihuahua, Chihuahua, y la especialización en lengua y literatura españolas en la Escuela Normal Superior José Medrano, en la capital de Chihuahua. Efectuó sus estudios en la Facultad de Derecho de la Universidad Nacional Autónoma de México, donde se tituló con la tesis Exclusión de figuras administrativas reguladas en el ordenamiento instrumental civil del Distrito Federal, su examen profesional se efectuó en 1978. Posteriormente realizó estudios de maestría y doctorado en derecho, en la UNAM. Rascón Banda estudió dirección teatral, desde 1977, en el Centro de Arte Dramático A. C. (CADAG), en dicho Centro tomó el seminario de creación dramática que impartía

202 Véase http://lenguasdeamerica.blogspot.mx. 
Este libro forma parte del acervo de la Biblioteca Jurídica Virtual del Instituto de Investigaciones Jurídicas de la UNAM

el escritor y periodista Vicente Leñero. Posteriormente asistió al taller de dramaturgia de Hugo Argüelles. En 1965 egresó de la Escuela Normal y a partir del 1o. de octubre de ese año le asignaron una plaza de profesor de educación primaria, misma que ocupó en Ciudad Juárez y en el Distrito Federal. Rascón inició su ejercicio profesional de abogado al titularse, ingresó a la Dirección de Asuntos Jurídicos del Consejo Nacional de Ciencia y Tecnología (Conacyt) donde adquirió gran experiencia en el área de propiedad intelectual. Hasta principios de la década de los ochenta ejerció la docencia en la Facultad de Derecho de la Universidad Nacional Autónoma de México paralelamente a sus actividades de servidor público; fue profesor fundador del Sistema de Universidad Abierta de dicha facultad. En 1982 ingresó al sector bancario ocupando la dirección administrativa del Banco Aboumrad, a finales del siglo XX concluyó su trabajo en ese sector fungiendo como director general de administración de los bancos Cremi, Unión, Oriente y Obrero, que en esa época fueron intervenidos por la Comisión Nacional Bancaria y de Seguros. Paralelamente a sus actividades como abogado Rascón Banda desarrolló su actividad dramatúrgica, y participó en la industria del celuloide como guionista de varias películas como Playa Azul (1991) y Morir en el Golfo (1990).

En 1998 comenzó a ocupar la presidencia de la Sociedad General de Escritores de México (Sogem), car- 
Este libro forma parte del acervo de la Biblioteca Jurídica Virtual del Instituto de Investigaciones Jurídicas de la UNAM

go que ejerció hasta su fallecimiento, el 31 de julio de 2008. En septiembre de 2002 fue elegido vicepresidente de la Confederación Internacional de Sociedades de Autores y Compositores (CISAG). Con motivo de su cargo en la Sogem, Rascón Banda participó activamente en la modificación de la normatividad del cine y derechos de autor, y fue un promotor del establecimiento del derecho a la cultura en la Constitución Política de los Estados Unidos Mexicanos, así como de la creación de la Ley de Fomento para la Lectura y el Libro.

Víctor Hugo Rascón Banda publicó dos textos autobiográficos, titulados Víctor Hugo Rascón Banda de cuerpo entero (UNAM, 1990) y ¿Por qué a mí? Diario de un condenado (Grijalbo, 2006). Escribió y publicó un libro de cuentos denominado Volver a Santa Rosa (Mortiz, 1996). Su obra póstuma fue una novela denominada Contrabando, escrita en 1991, editada hasta el 2008.

El abogado chihuahuense escribió más de cincuenta obras teatrales, sus principales líneas temáticas fueron la desigualdad social e injusticias que padecen las mujeres, los indígenas y los trabajadores migrantes. En su amplia producción sobresalen piezas teatrales donde se describen las prácticas delincuenciales en México, el universo de las prisiones, el fenómeno del narcotráfico, la corrupción gubernamental y los abusos de poder padecidos por guerrilleros, campesinos y otros grupos vulnerables. A continuación enuncio las obras más representativas creadas por Rascón: Apaches, Ar- 
Este libro forma parte del acervo de la Biblioteca Jurídica Virtual del Instituto de Investigaciones Jurídicas de la UNAM

mas blancas, Guerrero negro, Homicidio calificado, Hotel Juárez, La Malinche, La mujer que cayó del cielo, Los ilegales, Por los caminos del sur, Tina Modotti y Voces en el umbral.

Víctor Hugo Rascón publicó críticas teatrales en el semanario político Proceso, ${ }^{203}$ y artículos sobre teatro y cultura en las revistas Paso de gato. Revista mexicana de teatro, Tierra adentro, Revista de la Universidad de México. De manera esporádica publicó artículos en las secciones culturales de los periódicos El Financiero, Ovaciones y El Universal.

Desde su juventud y posterior a su fallecimiento el trabajo creativo del dramaturgo chihuahuense ha sido reconocido de diferentes formas, por lo que sobresalen los siguientes premios. En 1991 logró el Premio Juan Rulfo para Primera Novela, por Contrabando. En 1992 la obra La casa del español (adaptación de Voces en el umbral) fue merecedora de los premios Juan Ruiz de Alarcón y Rodolfo Usigli. ${ }^{204}$

203 Estudiosos de las ciencias de la comunicación consideraron el trabajo de Rascón Banda en la revista Proceso como un paradigma del crítico especialista "que publica sus trabajos en periódicos avalado por su nivel académico y su trayectoria profesional", véase Valles Ruiz, Rosa María, Taller de prácticas periodísticas II. Opinión periodística e influencia social, México, UNAM, Facultad de Ciencias Políticas y Sociales, 1995, p. 98.

204 Navarrete Maya, Laura, "Rascón Banda, Víctor Hugo (1948)", Diccionario de escritores mexicanos, México, UNAM, Instituto de Investigaciones Filológicas, 2004, t. VII, p. 95. 
Este libro forma parte del acervo de la Biblioteca Jurídica Virtual del Instituto de Investigaciones Jurídicas de la UNAM

En 2004 fue instituido el "Premio Nacional de Dramaturgia Víctor Hugo Rascón Banda” por el gobierno del estado de Nuevo León, el Consejo Nacional para la Cultura y las Artes, la Universidad Autónoma de Nuevo León y la Fundación Sebastián. ${ }^{205}$ En el 2006 Rascón Banda fue elegido para redactar el mensaje que se leyó el 27 de marzo de ese año, en teatros de las 200 naciones que integran la UNESCO, con motivo del Día Mundial del Teatro, esta pieza literaria se denominó "Un rayo de esperanza". ${ }^{206}$ Por otra parte, el teatro del Centro Cultural Paso del Norte, de Ciudad Juárez, Chihuahua (inaugurado en diciembre de 2006), lleva el nombre del dramaturgo originario de Uruáchi, Chihuahua. ${ }^{207}$ El 26 de junio de 2008 pronunció su discurso de ingreso a la Academia Mexicana de la Lengua, titulado "Un acto de fe", 208 mismo que fue respondido por Carlos Montemayor. En el 2010 este discurso fue publicado con el

205 Información publicada en la página electrónica del Consejo Nacional para la Cultura y las Artes, en wrerc.conaculta.gob.mx, 18 de mayo de 2004.

206 Discurso publicado en Victor Hugo Rascón Banda: Demiurgo de una teatralidad sin fronteras, Chihuahua, Instituto Chihuahuense de la Cultura, 2007.

207 Guía México Desconocido. Chihuahua, México, núm. 141, 2008, p. 26.

208 Revista de la Universidad de México, México, núm. 54, agosto de 2008. 
Este libro forma parte del acervo de la Biblioteca Jurídica Virtual del Instituto de Investigaciones Jurídicas de la UNAM

título Teatro, sociedad y democracia. Discurso de ingreso a la Academia Mexicana de la Lengua, 26 de junio de 2008, por la UNAM y la Academia Mexicana de la Lengua. ${ }^{209}$ En el 2008 la Legislatura LXIII del Congreso del estado de Chihuahua declaró a Rascón "chihuahuense distinguido" y estableció la Medalla al Mérito Cultural del estado de Chihuahua, Victor Hugo Rascón Banda, mediante el Decreto 280/08 II P.O., para premiar a las ciudadanas o los ciudadanos oriundos de dicho estado que se distingan por sobresalir en el ámbito cultural. Dicha distinción comenzó a entregarse a partir de 2009.

En agosto de 2009 el Consejo Técnico del Instituto de Ciencias Sociales y Administración de la Universidad Autónoma de Ciudad Juárez autorizó la Cátedra Patrimonial Víctor Hugo Rascón Banda, para hacer un reconocimiento académico al escritor chihuahuense, por ser uno de los dramaturgos más destacados a nivel nacional e internacional. Las labores de la Cátedra se iniciaron formalmente en abril 2010.210 En el 2015 se publicó un volumen con las conferencias ma-

209 Rascón Banda, Víctor Hugo, Teatro, sociedad y democracia. Discurso de ingreso a la Academia Mexicana de la Lengua, 26 de junio de 2008, México, UNAM, Coordinación de Difusión Cultural-Academia Mexicana de la Lengua, 2010.

210 Información proporcionada por la maestra Beatriz Rodas Rivera, coordinadora del Programa de Literatura, de la Universidad Autónoma de Ciudad Juárez, octubre de 2013. 
Este libro forma parte del acervo de la Biblioteca Jurídica Virtual del Instituto de Investigaciones Jurídicas de la UNAM

gistrales con las cuales se ha inaugurado la cátedra en sus primeros cinco años de existencia. ${ }^{211}$

Por otra parte, en homenaje a la memoria de Rascón Banda, en su cuarto aniversario luctuoso, el maestro Raúl García Velázquez, director de la Orquesta Sinfónica de la Universidad Autónoma de hihuahua compuso y estrenó la Cantata Apaches, inspirada en los textos de la obra teatral del mismo nombre escrita por Rascón Banda. La Cantata Apaches se estrenó el 9 de agosto de 2012, en la Ciudad de Chihuahua, en el Teatro de los Héroes.

Con la finalidad de hacer más accesible para los lectores el trabajo de Rascón Banda, el gobierno municipal de Uruáchi, con apoyo del Consejo Nacional para la Cultura y las Artes, publicó una serie de historietas que consta de cuatro volúmenes, mismos que tienen como tema los cuentos escritos por el autor chihuahuense bajo el título Volver a Santa Rosa, las historietas se presentaron en la XXXVII Feria Internacional del Libro del Palacio de Minería, en febrero de 2016.

211 Mijares Verdín, Enrique (comp.), Permanencia de un legado, México, Universidad Autónoma de Ciudad Juárez, 2015, Colección Cátedra Patrimonial Víctor Hugo Rascón Banda, vol. 1. 
Este libro forma parte del acervo de la Biblioteca Jurídica Virtual del Instituto de Investigaciones Jurídicas de la UNAM

\section{BIBLIOHEMEROGRAFÍA}

Aboites Aguilar, Luis, "José Fuentes Mares y la historiografía del norte de México. Una aproximación desde Chihuahua (1950-1957)", Historia Mexicana, México, vol. XLIX, núm. 3, enero-marzo de 2000. "Abren sala de arte colonial de don Artemio de ValleArizpe", El diario de Coahuila, México, 4 de noviembre de 2011.

Academia Mexicana de la Lengua, Anuario 2008, México, Academia Mexicana de la Lengua, 2007. AcLe Aguirre, Andrea, "Amigos y aliados: José Bernardo Couto (1803-1862) y José Joaquín Pesado (1801-1861)", Historia Mexicana, México, vol. LXI, núm. 1, julio-septiembre de 2011.

Alessio Robles, Vito, "Noticia biográfica", en RAMOS ARIZPE, Miguel, Discursos, memorias e informes, México, UNAM, Coordinación de Humanidades, 1994, Colección Biblioteca del Estudiante Universitario, núm. 36.

Alcubirre MOYA, Beatriz y RAmíRez GARrido, Jaime, "Martín Luis Guzmán: a la sombra de la Revolución”, Nexos, México, diciembre de 2011. 
Este libro forma parte del acervo de la Biblioteca Jurídica Virtual del Instituto de Investigaciones Jurídicas de la UNAM

Álvarez, José Rogelio, El diccionario universal de Orozco y Berra. Discurso de ingreso a la Academia Mexicana de la Lengua, 20 de febrero de 1992, México, UNAM-Coordinación de Difusión Cultural-Academia Mexicana de la Lengua, 2010.

Antecedentes históricos y Constituciones Politicas de los Estados Unidos Mexicanos, México, Secretaría de Gobernación, 2009.

Archivo de José María Luis Mora de la Colección latinoamericana Nettie Lee Benson de la Universidad de Texas en Austin, sección correspondencia de julio de 1833-1838, en http://lanic.utexas.edu/proyect/mora, consultado en noviembre de 2014.

ARNÁIZ y FrEG, Arturo "Cronología”, fosé María Luis Mora. Ensayos, ideas y retratos, México, UNAM, 2014, Biblioteca del Estudiante Universitario, núm. 25. Betancourt Cid, Carlos, "Martín Luis Guzmán", en TORRES PARÉS, Javier y Villegas MOREnO, Gloria (coords.), Diccionario de la Revolución mexicana, México, UNAM, 2010.

Bohmann, Karin, Medios de comunicación y sistemas informativos en México, México, Alianza Editorial-Consejo Nacional para la Cultura y las Artes, 1990. Bonifaz Nuño, Rubén, Calacas, México, Fondo de Cultura Económica, 2012.

ra Económica, 1996. 
Este libro forma parte del acervo de la Biblioteca Jurídica Virtual del Instituto de Investigaciones Jurídicas de la UNAM

, El Museo Amparo. Colección prehispánica, México, Museo Amparo, 1993.

, Imagen de Tláloc, hipótesis iconográfica y textual, México, UNAM, Coordinación de Humanidades, 1996.

, "Introducción", en REYES CORIA, Bulmaro et al., Acerca de fray Diego Valadés, su Retórica cristiana, México, UNAM, 1996.

- La fundación de la Ciudad, conferencia inaugural en El Colegio Nacional, México, en wrere.colegionacio nal.org.mx, consultado en septiembre de 2015.

, Olmecas: esencia y fundación. Hipótesis iconográfica y textual, México, El Colegio Nacional, 1992.

, Palabras de Rubén Bonifaz Nuño, al recibir de manos del señor presidente de la República, licenciado Luis Echeverría Álvarez, el Premio Nacional de Letras de 1974, en el auditorio del Museo Nacional de Antropología, el 28 de noviembre de 1974, en http://colegionacional.org.mx, consultado el 19 de septiembre de 2015.

, "Poesía de Gabilondo Soler a sus cien años", Revista de la Universidad de México, México, núm. 46, diciembre de 2007.

, “Quiénes somos los indios?” Conferencia inaugural, Ciclo Los pueblos indígenas y el Estado mexicano, en la Facultad de Derecho de la UNAM el 7 de noviembre de 1994, en http://colegionacional.org.mx, consultado el 19 de septiembre de 2015. 
Este libro forma parte del acervo de la Biblioteca Jurídica Virtual del Instituto de Investigaciones Jurídicas de la UNAM

-, Versos (1978-1994), México, Fondo de Cultura Económica, 1996.

BRAvO, Antonio, "Carlos Montemayor: voz que es Carmen, que es canto", Casa del tiempo, México, núm. 13, febrero de 2015.

BRiseño SENOSIAIN, Lillian, "José María Luis Mora, del sueño al duelo", en CLARK DE LARA, Belem y SPECKMAN GUERRA, Elisa (eds.), La república de las letras. Asomos a la cultura escrita del México decimonónico, México, UNAM, Coordinación de Humanidades, 2005, vol. III.

Bustamante, Carlos María de, Diario histórico de México enero-diciembre de 1824, México, Instituto Nacional de Antropología e Historia, 1981.

, Hay tiempos de hablary tiempos de callar, publicado en la página electrónica del Instituto Nacional de Estudios Históricos de las Revoluciones de México, http://inehrm.gob.mx.

Campillo Cuautli, Héctor, El himno nacional mexicano. Origen, historia y significado de nuestro Himno, México, Fernández Editores, 1998.

"Cancilleres de México. Siglo XX", en wrwr.sre.gob.mx, consultada el 17 de junio de 2014.

Cano Andaluz, Aurora, Biografias para niños. Fosé María Luis Mora, México, Instituto de Estudios Históricos de las Revoluciones de México, 1987.

Carballo, Emmanuel, Protagonistas de la literatura mexicana, México, Porrúa, 2003. 
Este libro forma parte del acervo de la Biblioteca Jurídica Virtual del Instituto de Investigaciones Jurídicas de la UNAM

Carbonell, Miguel, Forge Carpizo. Una vida entregada a la justicia, México, UNAM, Instituto de Investigaciones Jurídicas, 2012.

Cárdenas, Héctor, "Emilio O. Rabasa", en Galena, Patricia (coord.), Cancilleres de México. Siglo XX, Secretaría de Relaciones Exteriores, 1992.

CAstro, Germán, "La mapoteca Orozco y Berra", Relatos e historias de México, núm. 32, abril de 2011.

Celorio, Gonzalo, "Artemio de Valle Arizpe. Biógrafo de Fray Servando", Revista de la Universidad de México, en wrwerevistadelauniversidad.unam.mx/9311/pdf/ 93 celorio, consultada en 2014.

Colmenero, Sergio, Facultad de Ciencias Politicas y Sociales 1951-2001, México, UNAM, Facultad de Ciencias Políticas y Sociales, 2003.

Contreras Servín, Carlos, "Antecedentes históricos del ordenamiento territorial en México, la obra de Manuel Orozco y Berra", Boletín de los Sistemas $\mathrm{Na}$ cionales Estadísticos y de Información Geográfica, México, vol. 1, núm. 2, septiembre-diciembre de 2005.

Costeloe, Michael P., La República central en México 1835-1846. "Hombres de bien" en la época de Santa Anna, México, Fondo de Cultura Económica, 2000.

Couto, José Bernardo, Diálogo sobre la historia de la pintura en México, México, Consejo Nacional para la Gultura y las Artes, 1995. 
Este libro forma parte del acervo de la Biblioteca Jurídica Virtual del Instituto de Investigaciones Jurídicas de la UNAM

Covarrubias, Ana, "La política exterior «activa»... una vez más", Foro Internacional, México, vol. 68, núms. 1 y 2, 2008.

CRUZ BARNEY, Oscar, "Abogacía: una aproximación a sus organismos internacionales, condecoraciones y distinciones", Reforma Fudicial. Revista Mexicana de Fusticia, México, núms. 21 y 22, enero-diciembre de 2013.

, Defensa a la defensa y abogacía en México, México, UNAM, Instituto de Investigaciones Jurídicas-Ilustre y Nacional Colegio de Abogados de MéxicoIlustre Colegio de Abogados de Madrid, 2015. - La República central de Félix Zuloaga y el Estatuto Orgánico Provisional de la República de 1858, México, UNAM, Instituto de Investigaciones Jurídicas, 2009.

Curiel Defossé, Fernando, "Introducción", en GuZMÁN, Martín Luis, Caudillos y otros extremos. Antología, México, 2010, UNAM, Biblioteca del Estudiante Universitario, núm. 115.

Denegre VAught Alcocer, Jorge Ramiro (comp.), Dos siglos de discursos patrióticos. Colección Denegre Vaught Peña, México, UNAM, Instituto de Investigaciones Jurídicas, 2011.

"Ernesto de la Torre Villar", Cultura Mexicana 1942-1992, México, Seminario de Cultura Mexicana, 1992, sección Datos sobre los colaboradores. 
Este libro forma parte del acervo de la Biblioteca Jurídica Virtual del Instituto de Investigaciones Jurídicas de la UNAM

Escobedo Rojas, Alejandro G., "El Seminario Palafoxiano de la Puebla de los Ángeles: su mundo jurídico en los albores del Estado mexicano", en CRUZ BARNEY, Oscar et al. (coords.), Los abogados y la formación del Estado mexicano, México, UNAM, Instituto de Investigaciones Jurídicas, 2013.

Fernández MAG GRegor, Genaro, El doctor Mora redivivo (selección de sus obras), México, Botas, 1938.

FERnÁNDEZ RuIZ, Jorge, "Administración pública en la época de Juárez, en GaLEAnA, Patricia (coord.), Fuárez Furista, México, UNAM, Instituto de Investigaciones Jurídicas, 2006.

FIX-FIERrO, Héctor, "Los juristas académicos del Instituto de Investigaciones Jurídicas de la UNAM y la construcción jurídica de las nuevas instituciones democráticas", Los abogados y la formación del Estado mexicano, México, UNAM, Instituto de Investigaciones Jurídicas-Ilustre y Nacional Colegio de Abogados, 2013.

Galeana, Patricia, "El siglo XIX", en Galeana, Patricia (coord.), Los siglos de México, México, Nueva Imagen, 1991.

García Montero, Luis, La poesía como destino. Prólogo a la obra de Rubén Bonifaz Nuño, México, Fondo de Cultura Económica, 2012.

GARCía RIERA, Emilio, Breve historia del cine mexicano, primer siglo (1897-1997), México, Consejo Nacional para la Cultura y las Artes-Ediciones Mapa, 1998. 
Este libro forma parte del acervo de la Biblioteca Jurídica Virtual del Instituto de Investigaciones Jurídicas de la UNAM

GARCiADIEGO, Javier, "La gran revolución educativa. El triunfo de Vasconcelos", Relatos e Historias de México, México, núm. 75, noviembre de 2014.

GARRIDO, Felipe, "El siervo de la nación, José María Morelos", en Morelos Y PAVÓn, José María, Sentimientos de la Nación, México, Consejo Nacional para la Cultura y las Artes, 2010, Colección Summa Mexicana.

GARrido, Luis, El tiempo de mi vida. Memorias, México, Porrúa, 1974.

GARRIDO, Luis Javier, El Partido de la Revolución Institucionalizada, 7a. ed., México, Siglo XXI Editores, 1995. , "Introducción", en CHOMSKY, Noam y DiETERICH, Heinz, La sociedad global. Educación, mercado y democracia, México, Joaquín Mortiz, 1995.

- La ruptura. La corriente democrática del PRI, México, Grijalbo, 1993.

, "Prólogo", en Dietrich, Heinz (entrevistador), Noam Chomsky habla de América latina y México, México, Océano, 1998.

"Respeto a la Constitución", en CaMaCHO Solís, Manuel y VALADÉS, Diego (coords.), Gobernabilidad democrática: ¿Qué reforma?, México, Cámara de Diputados, LIX Legislatura-UNAM, Instituto de Investigaciones Jurídicas, 2004.

GARritz, Amaya, "Ernesto de la Torre Villar (19172009). In Memoriam”, en MAYER, Alicia (coord.), 
Este libro forma parte del acervo de la Biblioteca Jurídica Virtual del Instituto de Investigaciones Jurídicas de la UNAM

Un hombre de libros: homenaje a Ernesto de la Torre Villar, México, UNAM, Instituto de Investigaciones Históricas, 2012.

GonzÁlez PeÑa, Carlos, Historia de la literatura mexicana, México, Porrúa, 1998.

Guadarrama PeÑa, Guillermina, "Bocetos y secretos en los murales de San Ildefonso", en http://discursovi sual.cenart.gob.mx.

GuedeA, Virginia, "Centenario de la independencia, 1921 ", en TORRes PARÉs, Javier y Villegas, Gloria (coords.), Diccionario de la Revolución mexicana, México, UNAM, 2010.

GutiéRrez Nieto, Guillermo, "Instituto Matías Romero: 40 años forjando diplomáticos", Siempre, México, 10 de enero de 2015.

GuZMán, Martín Luis, "Apunte sobre una personalidad”, en GuzMán, Martín Luis, Obras completas, México, Fondo de Cultura Económica, 2013, t. II.

"Historia de 1944-1982", México, Comisión Nacional de Libros de Texto Gratuito, en wrw.conaliteg.gob.mx/ index.php, consultada en octubre de 2015.

IBARRA PALAFOX, Francisco (introducción y selección), El Congreso de Anáhuac y la Constitución de Apatzingán. Obra documental, México, UNAM, Instituto de Investigaciones Jurídicas, 2016.

Iglesias GonzÁlez, Román (recop.), Planes políticos, proclamas, manifiestos y otros documentos de la Independencia 
Este libro forma parte del acervo de la Biblioteca Jurídica Virtual del Instituto de Investigaciones Jurídicas de la UNAM

al México moderno, 1812-1940, México, UNAM, Instituto de Investigaciones Jurídicas, 1998.

José Vasconcelos. La creación de la Secretaría de Educación Pública, México, Instituto Nacional de Estudios Históricos de las Revoluciones de México, 2011.

Krauze, Enrique, Biografia del poder. Caudillos de la revolución mexicana (1910-1940), México, Tusquets Editores, 2002.

, Caudillos culturales en la Revolución mexicana, México, Siglo XXI Editores, 2000.

—_, La presencia del pasado, México, Tusquets, 2005. -, Mexicanos eminentes, México, Tusquets, 2012.

La sentencia de la Corte IDH. Caso Radilla Pacheco vs. Estados Unidos Mexicanos, México, Comisión Mexicana de Defensa y Promoción de los Derechos Humanos, 2010.

LOAEZA, Soledad, "En el principio fue el PRI", Nexos, México, febrero de 1984, en wrw.nexos.com.mx, consultado en mayo de 2015.

LÓPEz BetancourT, Eduardo, "Labor legislativa de la Soberana Junta Provisional Gubernativa del Imperio mexicano e intervenciones en la misma de Carlos María de Bustamante", en BERnAL, Beatriz (coord.), Memoria del IV Congreso de Historia del Derecho Mexicano (1986), México, UNAM, Instituto de Investigaciones Jurídicas, 1988, t. II.

LOZADA LEÓN, Guadalupe, "Introducción", fosé Vasconcelos hombre, educador y candidato, México, UNAM, 
Este libro forma parte del acervo de la Biblioteca Jurídica Virtual del Instituto de Investigaciones Jurídicas de la UNAM

Coordinación de Humanidades, 1998, Biblioteca del Estudiante Universitario, núm. 123. , "Un gran museo para el México antiguo", $R e^{-}$ latos e Historias de México, México, núm. 71, julio de 2014.

Luis Favier Garrido Platas (1941-2012): ante todo: un universitario, México, UNAM, Coordinación de Humanidades, 2012.

LunA, Andrés de (comp.), Martín Luis Guzmán, México, Cámara de Senadores de la República Mexicana, Legislatura LIII, 1987.

Macedo Jaimes, Graciela, "Breve estudio de las Constituciones del Estado de México", Anuario Mexicano de Historia del Derecho, México, vol. VIII, 1996.

MAHIEUX, Viviane, "Martín Luis Guzmán fracasa en la radio", Nexos, México, septiembre de 2012.

Mares, Roberto, fosé Vasconcelos, México, Grupo Editorial Tomo, 2004.

MARTÍNEZ LunA, Esther, "Diario de México: ilustrar a la plebe", en CLARK, Belem y SPECKMAN, Elisa (eds.), La república de las letras. Asomos a la cultura escrita del México decimonónico, México, Coordinación de Humanidades, 2005, vol. II.

Mateos Vega, Mónica, "Carlos Montemayor deja una vida de creación y compromiso", La fornada, México, 1o. de marzo de 2010.

Mayagoitia, Alejandro, "Don Mariano Pontón y Ponce: un jurista en una época de crisis. Notas para 
Este libro forma parte del acervo de la Biblioteca Jurídica Virtual del Instituto de Investigaciones Jurídicas de la UNAM

su biobibliografia", Anuario Mexicano de Historia del Derecho, México, núm. XV, 2003.

, "Juárez y el Ilustre y Nacional Colegio de Abogados de México. Libertades en jaque en el México liberal", Anuario Mexicano de Historia del Derecho, México, núm. XX, 2008.

México en el Diccionario universal de historia y geografia, La contribución de Orozco y Berra, México, UNAM, Coordinación de Humanidades, 2004, vol. III.

Mijares Verdín, Enrique (comp.), Permanencia de un legado, México, Universidad Autónoma de Ciudad Juárez, 2015, Colección Cátedra Patrimonial Víctor Hugo Rascón Banda, vol. 1.

Montemayor, Carlos, Arte y plegaria en las lenguas indigenas de México, México, Fondo de Cultura Económica, 2001.

, "La pluma del escribano", Cien años de Andrés Henestrosa, México, Fundación Sebastián, 2006. , "Nota introductoria", Material de lectura. Rubén Bonifaz Nuño, México, UNAM, Coordinación de Difusión Cultural, 2008, Colección poesía moderna, núm. 23.

xico, Editorial Aldus, 1999.

(coord.), Diccionario del náhuatl en el español de México, México, UNAM, Programa México Nación Multicultural-Gobierno del Distrito Federal, 2007. 
Este libro forma parte del acervo de la Biblioteca Jurídica Virtual del Instituto de Investigaciones Jurídicas de la UNAM

Monterde, Francisco, "Prólogo", Dos novelas de la Revolución. Los de abajo. La sombra del caudillo, México, Secretaría de Educación Pública-UNAM, 1982.

MORA, José María Luis, México y sus revoluciones, 4a. ed., México, Porrúa, 1986.

-, Obras sueltas, París, Librería de Rosa, 1837.

, "Semblanza autobiográfica", José María Luis

Mora. Ensayos, ideas y retratos, México, UNAM, 2014,

Biblioteca del Estudiante Universitario, núm. 25.

Muro, Luis, "Bibliografía de José Fuentes Mares", publicada en http://biblio-codex.colmex.mx/exlibris/aleph, consultada el 5 de julio de 2014.

NAVARRete MaYA, Laura, "Rascón Banda, Víctor Hugo (1948)", Diccionario de escritores mexicanos, México, UNAM, Instituto de Investigaciones Filológicas, 2004, t. VII.

"Nota introductoria", en Fuentes MAREs, José, Arte del bien comer y del mejor beber, México, Fondo de Cultura Económica, 2000.

Notimex, "Destapan a Luis Javier Garrido para dirigir la UNAM", El Universal, México, 17 de octubre de 2007.

NovedADES DEL PASADO, "La otra fiesta de las balas", Relatos e historias en México, México, núm. 86, octubre de 2015.

Obras del doctor D. Fosé Bernardo Couto, México, Imprenta de Victoriano Agüeros, 1898, t. I. 
Este libro forma parte del acervo de la Biblioteca Jurídica Virtual del Instituto de Investigaciones Jurídicas de la UNAM

O’Gorman, Edmundo, Guía bibliográfica de Carlos María de Bustamante, México, Fundación Cultural Condumex, 1967.

Orozco y Berra, Manuel, Memoria para el plano de la Ciudad de México, México, Imprenta de Santiago White, 1867.

- Memoria para la carta hidrográfica del Valle de México, México, Imprenta de A. Boix, 1864.

Pampillo Baliño, Juan Pablo, Manuel de la Peña y Peña. Un jurista de la Suprema Corte de Justicia de la Nación, México, Suprema Corte de Justicia de la Nación, 2009. Payno, Manuel, Los bandidos de Río Frío, 26a. ed., México, Porrúa, 2011.

Pi-SuÑer Llorens, Antonia (coord.), "Estudio preliminar", Catálogo de los artículos sobre México en el Diccionario Universal de Historia y de Geografia, México, UNAM, Facultad de Filosofía y Letras, 1997.

Prieto, Guillermo, Memorias de mis tiempos, 3a. ed., México, Porrúa, 2004.

Quintana, José Miguel, Lafragua. Político y romántico, México, Editorial Academia Literaria, 1958.

RABASA, Emilio O., "El pensamiento constitucional de Venustiano Carranza (análisis de su mensaje del 1o. de diciembre de 1916 al presentar el proyecto de Constitución)", Anuario Mexicano de Historia del Derecho, México, vol. VII, 1995.

, "La participación de México en la fundación de la ONU y sus reformas", Un homenaje a don César 
Este libro forma parte del acervo de la Biblioteca Jurídica Virtual del Instituto de Investigaciones Jurídicas de la UNAM

Sepúlveda. Escritos jurídicos, México, UNAM, Instituto de Investigaciones Jurídicas, 1995.

"La zona económica exclusiva (artículo 27, párrafo octavo)", Ochenta años de vida constitucional en México, México, UNAM, Instituto de Investigaciones Jurídicas, 1998.

Rascón Banda, Víctor Hugo, Armas blancas, México, Universidad Nacional Autónoma de México, 1990. Fugitivos), México, Instituto de Seguridad y Servicios Sociales de los Trabajadores del Estado, 1999. , Homicidio calificado, México, Editores Mexicanos Unidos, 2003.

, "Hotel Juárez", Paso de Gato, México, núm. 6, enero de 2003.

- Intolerancias. Tres obras de teatro. Apaches, El deseo y Mujeres que beben vodka, México, Universidad Nacional Autónoma de México-Casa Juan Pablos, 2005.

-, La Malinche, México, Plaza y Janés, 2000. 2000.

- La mujer que cayó del cielo, México, Escenología, , "Los ilegales", Teatro de la Frontera 13/14. Victor Hugo Rascón Banda, Durango, Siglo XXI-ConacultaFonca-Universidad Juárez de Durango, 2004.

"Por los caminos del sur", Teatro clandestino de Rascón Banda, México, Libros de Godot-Universidad Autónoma de Chihuahua, 2009. 
Este libro forma parte del acervo de la Biblioteca Jurídica Virtual del Instituto de Investigaciones Jurídicas de la UNAM

, Teatro, sociedad y democracia. Discurso de ingreso a la Academia Mexicana de la Lengua, 26 de junio de 2008, México, UNAM, Coordinación de Difusión Cultural-Academia Mexicana de la Lengua, 2010.

, "Un acto de fe", Revista de la Universidad de México, México, núm. 54, agosto de 2008.

- Víctor Hugo Rascón Banda: demiurgo de una teatralidad sin fronteras, Chihuahua, Instituto Chihuahuense de la Cultura, 2007.

, "Voces en el umbral", Tina Modottiy otras obras de teatro, México, Secretaría de Educación Pública, 1986. Reyes CORiA, Bulmaro, "Bonifaz el filólogo, está bien", Revista de la Universidad de México, núm. 109, marzo de 2013.

RiverA, Diego, "Carta a Martín Luis Guzmán”, París, 2 de febrero de 1916, en GuzMán, Martín Luis, La querella de México, México, Conaculta-Planeta, 2002.

Rivera GÓmEZ, Nidia, "El físico sí importa. En 1923 se creó la Escuela Elemental de Educación Física como parte del proyecto vasconcelista", Relatos $e$ Historias en México, México, núm. 77, enero de 2015. Rodríguez Gastañeda, Rafael, Prensa vendida. Los periodistas y los presidentes: 40 años de relaciones, México, Grijalbo, 1993.

Rojas Garcíadueñas, José, Don José Bernardo Couto, jurista diplomático y escritor, Xalapa, Universidad Veracruzana, 1964. 
Este libro forma parte del acervo de la Biblioteca Jurídica Virtual del Instituto de Investigaciones Jurídicas de la UNAM

Rosas, Alejandro, José Vasconcelos, México, Consejo Nacional para la Cultura y las Artes, 2008. , "Unidos por el exilio Calles y Vasconcelos en Estados Unidos", Relatos e Historias de México, México, núm. 51, noviembre de 2012.

Ruiz Castañeda, María del Carmen, "El Diario de México (1805-1817)", en REED TORRES, Luis y Ruiz Castañeda, María del Carmen, El periodismo en México, 500 años de historia, 3a. ed., México, Edamex, 1995.

, "La prensa científica y literaria (1830-1850)", Gaceta Bibliográfica, México, núm. 22, abril-junio de 2003.

Silva Herzog, Jesús, El doctor Mora, economista, México, 1950, en wrere.colegionacional.org.mx/SACSCM, consultado en diciembre de 2014.

Soberanes, José Luis y Vega Gómez, Juan, El Tratado de Guadalupe Hidalgo en su sesquicentenario, México, UNAM, Instituto de Investigaciones Jurídicas, 1998.

Sodi Pallares, Ernesto, Pinacoteca Virreinal de San Diego, México, Populibros La Prensa, 1969.

SosA, Francisco, Biografias de mexicanos distinguidos, México, Porrúa, 2006.

TalaverA, Juan Carlos, "Salvan acervo mayor; Archivo Manuel Orozco y Berra", Excélsior, México, 10 de junio de 2015. 
Este libro forma parte del acervo de la Biblioteca Jurídica Virtual del Instituto de Investigaciones Jurídicas de la UNAM

TORRE REnDÓn, Judith de la, "José María Lafragua Ibarra", Cancilleres de México siglo XIX, México, Secretaría de Relaciones Exteriores, 1992.

TORRE VilLAR, Ernesto de la, Breve historia del libro en México, 2a. ed., México, UNAM, Dirección General de Publicaciones y Fomento Editorial, 2009.

"Estudio preliminar", en BARQUERA, Juan Wenceslao, Lecciones de política y derecho público para la instrucción del pueblo mexicano, México, UNAM, Instituto de Investigaciones Jurídicas, 1991.

, Ex libris y marcas de fuego, 2a. ed., México, UNAM, Dirección General de Publicaciones y Fomento Editorial, 2000.

-, "José Fernando Ramírez", en Clark, Belem y SPECKMAn, Elisa (eds.), La república de las letras. Asomos a la cultura escrita del México decimonónico, México, Coordinación de Humanidades, 2005, vol. III.

, La Constitución de Apatzingán y los creadores del Estado mexicano, 2a. ed., México, UNAM, Instituto de Investigaciones Históricas, 2010.

, "La Constitución de 1824", en VALADÉS, Diego y BARCELÓ, Daniel (coords.), Examen retrospectivo del sistema constitucional mexicano. A 180 años de la Constitución de 1824, México, UNAM, Instituto de Investigaciones Jurídicas, 2005.

, "La Iglesia en México: de la Guerra de Independencia a la Reforma. Notas para su estudio", 
Este libro forma parte del acervo de la Biblioteca Jurídica Virtual del Instituto de Investigaciones Jurídicas de la UNAM

Estudios de Historia Moderna y Contemporánea de México, México, vol. 1, 1965.

- La independencia de México, 2a. ed., México, Fondo de Cultura Económica, 2010.

-, "La política americanista de fray Servando y Tadeo Ortiz", Estudios de Historia Moderna y Contemporánea de México, México, vol. 8, 1980.

, "Las bibliotecas de José Fernando Ramírez",

en RAMírez, José Fernando, Obras históricas, IV. Bibliografia y biografia, México, UNAM, Instituto de Investigaciones Históricas, 2002.

"Las sociedades de amigos del país y Juan Wenceslao Barquera", Estudios de Historia Moderna y Contemporánea de México, México, vol. 14, 1991. , "México y su Biblioteca Nacional 1867-1967", Revista de la Universidad de México, vol. XXII, núm. 6, febrero de 1968.

-, "Minorías religiosas en la novela mexicana del siglo XIX", Estudios de Historia Moderna y Contemporánea de México, México, vol. 12, 1989.

"Preliminar", en García Ramírez, Sergio, Escritos literarios, México, Seminario de Cultura Mexicana, 2005.

, "Prólogo", en LAfragua, José María y OrOzCO y Berra, Manuel, La Ciudad de México, México, Porrúa, 1998.

TIBOL, Raquel, "Diego Rivera dibujante", Diego Rivera gran ilustrador, México, Museo Nacional de Arte, 2007. 
Este libro forma parte del acervo de la Biblioteca Jurídica Virtual del Instituto de Investigaciones Jurídicas de la UNAM

—, Diego Rivera luces y sombras, México, Lumen, 2007.

Trueba Buenfil, Fernando e IbARrola Muro, Jorge Claudio, El arte de la memoria notarial. Los trabajos y los días del Estado de México 1808-1937, México, Gobierno del Estado de México, 2013.

U TUMBEN K'AARILO'OB X-YA'AXCHE', U meyaj bejlabeno'ob maaya aj ts'ïbo'ob ti'u petenil Yúucataane' (Los nuevos cantos de la ceiba, Antología de escritores mayas contemporáneos de la península de Yucatán), MONTEMAYOR, Carlos y Frischmann, Donald H. (antologadores), México, Gobierno de Yucatán, Instituto de Cultura de Yucatán, 2009.

UlloA, Berta, "La lucha armada (1911-1920)", Historia General de México, 3a. ed., México, El Colegio de México, 1981, t. II.

VALADÉS, Diego, "Prólogo", en MONTIEL Y DUARTE, Isidro, Tratado de las leyes y su aplicación, México, UNAM, Dirección General de Publicaciones, 1978.

, Perfiles académicos, México, Academia Mexicana de la Lengua, 2015.

"Reflexiones sobre el Estatuto Orgánico de 1856", Nueva gaceta bibliográfica, México, año 16, núm. 64, octubre-diciembre de 2013.

VALAdÉS, José C., Orígenes de la República mexicana. La aurora constitucional, México, UNAM, Coordinación de Humanidades, 1994. 
Este libro forma parte del acervo de la Biblioteca Jurídica Virtual del Instituto de Investigaciones Jurídicas de la UNAM

VALlE-ARIZPE, Artemio de, "Historia de una vocación”, en VAlle ARIzPE, Artemio de, Obras, México, Fondo de Cultura Económica, 2000, t. I.

, Historia, tradiciones y leyendas de calles de México, México, Diana, 1978.

Porrúa, 2000.

VAlLes RuIZ, Rosa María, Taller de prácticas periodísticas II. Opinión periodística e influencia social, México, UNAM, Facultad de Ciencias Políticas y Sociales, 1995.

VAsconcelos, José, Hernán Cortés, creador de la nacionalidad, México, Trillas, 2010.

-, La raza cósmica, México, Porrúa, 2007.

, Ulises criollo, 3a. ed., México, Porrúa, 2001.

VÁZQUEZ, Josefina Zoraida, "El establecimiento del México independiente (1821-1848)", en WOBESER Von, Gisela, Historia de México, México, Presidencia de la República-Fondo de Cultura Económica, 2010 .

- México y el mundo. Historia de sus relaciones exteriores, México, El Colegio de México, 2010, t. I.

"Presentación", en Bustamante, Carlos María de, El nuevo Bernal Díaz del Castillo, o sea, historia de la invasión de los angloamericanos en México, México, Consejo Nacional para la Cultura y las Artes, 2005. 
Este libro forma parte del acervo de la Biblioteca Jurídica Virtual del Instituto de Investigaciones Jurídicas de la UNAM

Vega Alfaro, Eduardo de la, La Revolución traicionada. Dos ensayos sobre literatura, cine y censura, México, UNAM, Centro Universitario de Estudios Cinematográficos, 2012.

VillalPando CÉSAR, José Manuel, "José Fuentes Mares, historiador mexicano", Estudios de Historia moderna y contemporánea de México, México, vol. 12, 1989. , Los monumentos a Cristóbal Colón en la Ciudad de México, México, en wrwe.inehrm.gob.mx.

YANkelevich, Pablo, "Los ecos de la Revolución mexicana en Latinoamérica", Relatos e Historias en México, México, núm. 16, diciembre de 2009.

Decreto por el que se crea el Instituto de Investigaciones José María Luis Mora, como organismo público descentralizado, México, Diario Oficial de la Federación, 30 de septiembre de 1981.

Dictamen de la Comisión Especial de la Cámara de Senadores, sobre el cambio de la forma de gobierno, y voto particular del Sr. Couto, México, imprenta del Águila, 1835.

Estatuto orgánico de la Comisión Nacional de Libros de Texto Gratuito, Diario Oficial de la Federación, México, 5 de marzo de 2008.

Legislación mexicana o Colección completa de las disposiciones legislativas expedidas desde la independencia de la República, ordenadas por Manuel Dublán y José María Lozano, en http://biblio.colmex. $m x /$ bib.dig. 
Abogados creadores de cultura, editado por el Instituto de Investigaciones Jurídicas de la UNAM, se terminó de imprimir el 7 de abril de 2017 en MGM, Consultoría Gráfica, S. A. de C. V., Fuentes Brotantes 43-1, colonia Portales Oriente, delegación Benito Juárez, 03570 Ciudad de México, tel. 52439110. Se utilizó tipo Baskerville de 9, 10 y 11 puntos. En esta edición se empleó papel cultural $57 \times 87$ de 75 gramos para los interiores y cartulina couché de 250 gramos para los forros; consta de 200 ejemplares (impresión digital). 
ste libro contiene biografías breves de quince abogados mexicanos, quienes dedicaron su ejercicio profesional a la implementación y al desarrollo de la normatividad jurídica en instituciones públicas de los ramos educativo y cultural en los siglos XIX a XXI. 